
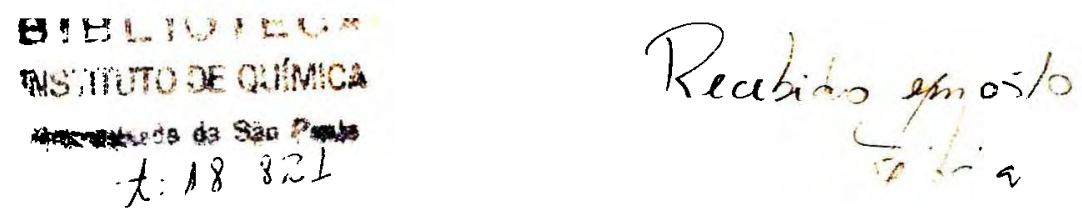

Universidade de São Paulo

Instituto de Química

\title{
INTERAÇÕES ENTRE VESÍCULAS SINTÉTICAS OU FOSFOLIPÍDICAS E SUPERFÍCIES DE ÓXIDO DE SILÍCIO
}

Renata Rapuano

Dissertação de Mestrado

Orientadora: Ana Maria Carmona-Ribeiro

São Paulo 

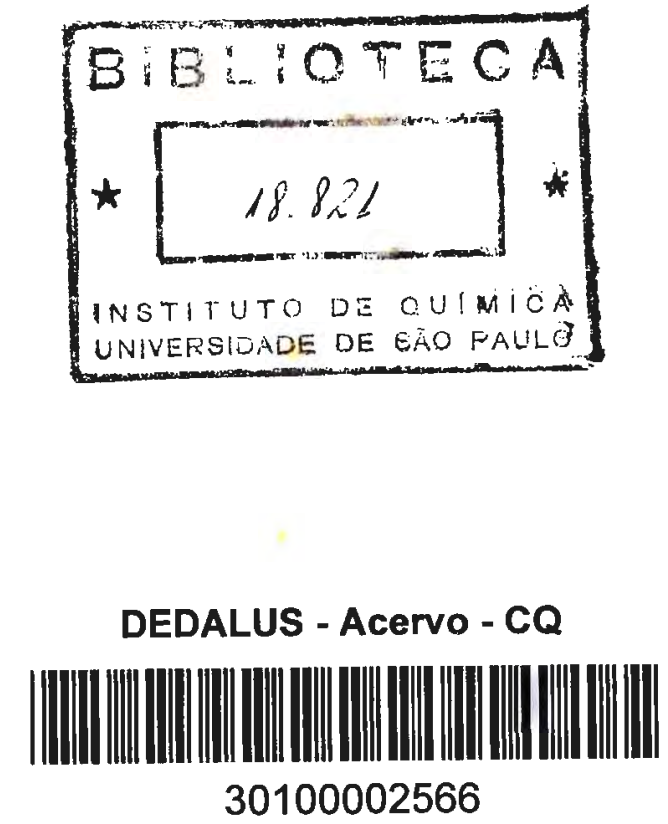

Ficha Catalográfica

Elaborada pela Divisão de Biblioteca e

Documentacão do Conjunto das Quimicas da USP.

Rapuano. Renata
R121i Interações entre vesículas sintéticas ou fosfolipídicas e superfícies de óxido de sílicio / Renata Rapuano -. São Paulo, 2000.

$126 \mathrm{p}$.

Dissertação (mestrado) - Instituto de Química. Departamento de Bioquimica.

Orientadora: Carmona-Ribeiro. Ana Maria

1. Biofísica 2. Lipossoma : Bioquímica I. T. 11 . Carmona-Ribeiro. Ana Maria, orientadora. 


\title{
"Interações Entre Vesículas Sintéticas ou Fosfolipídicas e Superfícies de Óxido de Silício"
}

\section{RENATA RAPUANO}

Dissertação de Mestrado submetida ao Instituto de Química da Universidade de São Paulo como parte dos requisitos necessários à obtenção do grau de Mestre em Ciências - Área: Bioquímica.

Aprovado por:

\author{
Profa. Dra. A NA MARIA CARMONA RIBEIRO \\ IQ - USP \\ (Orientadora e Presidente)
}
Profa. Dra. DENISE FREITAS SIQUEIRA PETRI
IQ - USP

Profa. Dra. LIGIA FERREIRA GOMES

FCF - USP

SÃo PAULO

28 DE ABRIL DE 2000. 
À minha mãe, Edith Keller Rapuano, pelo grande apoio durante toda a minha vida, sem a qual não estaria onde estou. À memória de meu pai, Nélio Rapuano, que com certeza de onde estiver, sempre esteve olhando por mim. Aos meus irmãos, Lídia e Nelinho, pela amizade. Aos meus queridos sobrinhos, Nathália e Iago, pelos momentos de distração. E ao Edgard Gonçalves Fernandes Júnior, pelo companheirismo e compreensão. Sem vocês minha vida jamais seria completa. 


\section{AGRADECIMENTOS}

À Dra. Ana Maria Carmona-Ribeiro, pela orientação competente durante todo o decorrer do trabalho e por ter me iniciado na pesquisa científica.

Ao Professor Dr. Miguel Jafelicci Júnior, da Universidade Estadual Paulista (UNESP) - campus de Araraquara - pela determinação da área superficial específica das partículas de sillica.

À Sandra Micelli Sicchierolli, por ter me apresentado a linha de pesquisa do laboratório.

A todos que passaram pelo grupo no decorrer do trabalho, Liflian Rumi Tsuruta, Lyzethe Mayra e Souza Martins, Livia Araújo, Daniel B. Nascimento, Denise da S. Matos e Allan dos Santos.

Às companheiras de trabalho, Edla Mores de Abreu, Myriam Therezinha Neves Campanhã, Irene Satiko Kikuchi e Sonia.

À professora Maria Regina Alcântara, pelos preciosos conselhos e amizade.

Ao Ivan Tadeu Rebustini, pelas conversas animadoras e companheirismo durante a monitoria, o que gerou uma boa amizade.

À Marcela Gerardo Ribeito, Sandra Kiyoko Tadokoro, Ricardo Prado Millen e Paulo Alexandre Rebelo Galvinas pela amizade durante toda a nossa caminhada.

Aos funcionários e técnicos do IQUSP, pelos favores prestados.

À FAPESP pelo apoio financeiro. 


\section{RESUMO}

Isotermas de adsorção de anfifilicos sintéticos formadores de bicamaáas ou fosfolipídios a partir de vesículas sobre partículas de silica hidrofilica (AEROSIL OX-50) foram obtidas em diversas condições experimentais. Vesículas pequenas de fosfatidilcolina (PC), dipalmitoilfosfatidilcolina (DPPC), dihexadecilfosfato (DHP) e brometo de dioctadecildimetilamônio (DODAB) dispersas em $10 \mathrm{mM}$ de dois diferentes tampões (Tris ou HEPES) em 3 diferentes valores de $\mathrm{pH}$ apresentam afinidades pela sílica que seguem a seqüência: $\mathrm{DODAB}>\mathrm{DPPC}>\mathrm{PC}>\mathrm{DHP}$. Deposição de bicamada de fosfolipídio é favorecida pela presença de Tris como tampão em $\mathrm{pH} \leq 7,4$, e temperaturas acima da temperatura de transição de fase para bicamada de fosfolipídio. Interação a $65{ }^{\circ} \mathrm{C}$ por 1 hora entre vesículas de DPPC e silica eficientemente gera a deposição de bicamada com uma adsorção máxima, se Tris é o tampão utilizado. Consistentemente, a molhabilidade de superfícies planares de $\mathrm{SiO}_{2}$ em condições de deposição de bicamada (como descrita pelas isotermas de adsorção) na presença de vesículas lipídicas mostra um grande aumento da hidrofobicidade da superfície para vesículas de DPPC a $65^{\circ} \mathrm{C}$ e DODAB em temperatura ambiente. Redução na absorção de luz pela MC540 em $565 \mathrm{~nm}$ foi usada como indicativa de deposição de bicamada sobre partículas de silica. Durante a interação com partículas sólidas, a absorbância a $565 \mathrm{~nm}$ mostra uma diminuição que corresponde a porcentagem de marcador que se intercala entre a bicamada e a partícula sólida e, conseqüentemente, se esconde da luz incidente. Para DPPC, à $65^{\circ} \mathrm{C}$, e $\mathrm{DODAB}$ à temperatura ambiente, mas não para $\mathrm{PC}$, a ocorrência de deposição de bicamada, descrita pelas isotermas de adsorção, é confirmada pelas três técnicas empregadas para detecção. 


\section{ABSTRACT}

Adsorption isotherms of bilayer-forming synthetic amphiphiles or phospholipids from vesicles onto hydrophilic silica particles (AEROSIL 0X-50) are obtained over a range of experimental conditions. Phosphatidylcholine (PC), dipalmitoylphosphatidylcholine (DPPC), and dioctadecyldimethylammonium bromide (DODAB) dispersed in $10 \mathrm{mM}$ of two different buffers (Tris or HEPES) at 3 different $\mathrm{pH}$ values as small unilamellar vesicles present affinities for silica following the sequence: DODAB $>$ DPPC $>$ PC. Deposition of phospholipid bilayers was favoured by the presence of Tris as buffer, $\mathrm{pH} \leq 7.4$, and temperatures above the phase transition temperature ( $\mathrm{Tc}$ ) for the phospholipid bilayer. Interaction at $65^{\circ} \mathrm{C}$ for $1 \mathrm{~h}$ between DPPC vesicles and silica efficiently leads to bilayer deposition at maximal adsorption, if Tris is the buffer used. Consistently, wettability of $\mathrm{SiO}_{2}$ planar surfaces precisely under conditions of bilayer deposition (as depicted from the isotherms) in the presence of the lipidic vesicles yielded a large increase on surface hydrophobicity for DPPC at $65^{\circ} \mathrm{C}$ and DODAB at room temperature. Reduction of merocyanine 540 absorbance at $565 \mathrm{~nm}$ was used as a marker for bilayer deposition onto the silica particles. Upon interaction with the solid particle, absorbance at $565 \mathrm{~nm}$ displays a decrease with time that corresponds to the percentage of dye that became sandwiched between the bilayer and the solid particle surface and thereby hidden from the incident light. For DPPC at $65^{\circ} \mathrm{C}$ and DODAB at room temperature, but not for PC, occurrence of bilayer deposition depicted from the adsorption isotherms is confirmed from the three techniques employed for detection. 


\section{ABREVIAÇÕES}

BET - Brunauer, Emmett, Teller

CMC - Concentração micelar crítica

DHP - dihexadecilfosfato

DLVO - Dejarguin, Landau, Verwey, Overbeek

DODAB - brometo de dioctadecildimetilamônio

DPPC - dipalmitoilfosfatidilcolina

HEPES - 4-(2-hidroxietil)-1-ácido piperazinosulfônico

MC540 - merocianina 540

PC - fosfatidilcolina

Tris - 2-(hidroximetil)-2-amino-1,3-propanodiol 


\section{ÍNDICE}

Resumo

Abstract

Abreviações

I - Introdução 1

I.1 - Introdução geral 1

I.2 - Auto - associação de moléculas anfifilicas 3

I.2.1 - Tïpos de anfifilicos 3

1.2.2 - Fatores que determinam a auto-associaģão de anfifilicos 6

I.2.3 - Anfifilicos formadores de bicamadas 11

$\begin{array}{ll}\text { I.3 - Superfícies de } \mathrm{SiO}_{2} & 17\end{array}$

$\begin{array}{ll}\text { I.3.1 - Particulados } & 20\end{array}$

I.3.1.1 - Tipos de silica $\quad 22$

I.3.1.2 - Caracterizą̧ão de particulados $\quad 24$

I.3.1.3 - AEROSIL OX-50 26

I.3.2 - Superficies planares de $\mathrm{SiO}_{2}$ obtidas por oxidação térmica 28

I.3.2.1 - Caracterizą̧ão de superfícies 29

I.3.2.1.1 - Angulo de contato 29

I.3.2.1.2 - Elipsometria $\quad 36$

I.4 - Forças de interação $\quad 40$

I.4.1 - Interą̧ões entre bicamadas e superfícies 46

I.4.2 - Isotermas de adsorção $\quad 51$

I.4.2.1 - Täpos de isotermas $\quad 52$

I.4.2.2 - Modelo de Langmuir $\quad 55$

I.5 - Merocianina 540

II - Materiais e métodos $\quad 62$

II.1 - Obtenção de anfifilicos e preparação de vesículas 62

II.2 - Obtenção e caracterização das partículas de silica 63

II.3 - Obtenção das superfícies planares de $\mathrm{SiO}_{2} \quad 64$

II.4 - Determinação de isotermas de adsorção de anfifflicos a partir de vesículas 64 sobre partículas de silica MC540

II.5 - Verificação de eventual interdigitação de vesículas fosfolipídicas usando 70

II.6 - Determinação do efeito de partículas de $\mathrm{SiO}_{2}$ sobre os espectros de 70 absorção de luz pela MC540 incorporada em membranas lipídicas 
II.8 - Determinação do ângulo de contato dinâmico de superfície planar $\mathrm{de}_{\mathrm{SiO}_{2}} \quad 72$ em presença de dispersões de vesículas

III - Resultados e discussão

III.1 - Deposição de fosfolipídio como bicamada sobre sillica hidrofilica 75

III.2 - Deposição de anfifilicos sintéticos catiônicos e aniônicos formadores de 84 bicamadas sobre silica.

III.3 - Deposição de bicamada a partir de vesículas sobre partículas sólidas determinada por oclusão de merocianina 540

III.4 - Efeito de vesículas sobre a molhabilidade de óxido de silicio 106

IV - Conclusões

V - Perspectivas

VI - Referências bibliográficas 


\section{I - Introdução}

\section{I.1 - Introdução Geral}

O objetivo deste trabalho é estudar a interação entre membranas-modelo de anfifilicos sintéticos e fosfolipídios e partículas de sílica hidrofilica.

Tal trabalho é justificado tanto do ponto de vista tecnológico quanto no que diz respeito ao aspecto fenomenológico.

Sob o ponto de vista tecnológico tem-se que inúmeros materiais orgânicos podem ser usados para criar novos sensores capazes de medir parâmetros físicos, químicos e biológicos [De Rossi et al., 1994], além de propiciarem a construção de "kits" imunológicos e o desenvolvimento de materiais biocompativeis.

A nível biológico, os principais componentes moleculares envolvidos em transdução de sinal através de membrana celular e em reconhecimento molecular são as proteínas [Gennis, 1989]. Estas podem atuar como ligantes (a insulina, por exemplo, é um hormônio peptídico, as toxinas bacterianas são proteínas de baixo peso molecular, que se ligam a receptores específicos da membrana celular). A própria ligação antígeno - anticorpo é um exemplo importante de uma interação receptor - ligante, onde ambos os componentes do par são proteínas.

Freqüentemente, os receptores protéicos possuem elevado peso molecular, e são pouco solúveis em água, necessitando de um microambiente hidrofóbico/hidrofilico adequado para adquirir sua conformação funcional. Esse microambiente ideal é oferecido pela bicamada fosfolipídica que compõe a matriz da membrana celular. A grande vantagem dos receptores, do ponto de vista sensorial, é a elevadíssima especificidade e sensibilidade com que fazem o reconhecimento biomolecular.

Por outro lado, o projeto de "kits" de imunoensaios baseado em partículas de silica, teria algumas vantagens sobre aqueles baseados em microesferas de látex, 
como por exemplo, o menor custo e a maior área superficial. Além disso, a construção de biosensores requer a montagem da circuitaria sobre superfícies de óxido de silício.

A deposição de vesículas em interfaces sólido-líquido depende inicialmente de uma força repulsiva devido à interação das duplas camadas elétricas associada com a carga da vesícula e a carga superficial do sólido e de uma força de dispersão atrativa entre a vesícula e o sólido, de caráter eletrodinâmico (van der Waals). Vesículas não são, no entanto, estruturas permanentemente rígidas, e dependendo do seu tamanho e composição química de seu meio aquoso, podem sofrer distorções, agregação, rompimento e fusão. Deposição de vesículas sobre superfícies sólidas pode ser resultado de um ou uma combinação desses processos [Jackson et al., 1986].

Desse modo, poderá ser interessante combinar a alta especificidade e sensibilidade dos receptores com a elevada área superficial das partículas de óxido de silício.

Sob o aspecto fenomenológico, a imobilização de bicamadas lipídicas em superfícies sólidas é importante, pois tal sistema pode ser usado como membranamodelo para o estudo de reconhecimento célula-célula no sistema imune [McConnell et al., 1992], adesão celular [Stelzle e Sackmann, 1989], adesão de membranas reparadoras [Seifert et al, 1993], ligação de proteínas em lipídios ligantes [Kalb et al, 1990, Schmidt et al., 1992], e para inserção de proteínas em membranas [Ramsden e Schneider, 1993]. Além disso, a interação de bicamadas lipídicas com superfícies tanto no que diz respeito aos diversos modos de autoorganização na interface, quanto no que tange as forças intermoleculares que regem tal interação, é um fenômeno pouco compreendido.

Desse modo, tem-se por objetivo neste trabalho realizar o estudo da adsorção física de membranas-modelo em partículas de sílica, com uma extensão 
englobando determinação de ângulo de contato para superfícies planares de óxido de silício para caracterizar mudanças de molhabilidade causadas pelas membranas.

As membranas-modelo utilizadas neste trabalho foram obtidas a partir dos seguintes anfifilicos que formam bicamadas: brometo de dioctadecildimetilamônio (DODAB), dihexadecilfosfato (DHP), fosfatidilcolina $\quad$ (PC) $\mathrm{e}$ dipalmitoilfosfatidilcolina (DPPC).

A caracterização desta adsorção foi feita attavés de determinação de isotermas de adsorção, que nos dão informação de quantidade de anfifilico adsorvido por metto quadrado de silica em função da concentração de anfifílico que resta no sobrenadante; oclusão da merocianina 540 (MC540), que é um marcador da superfície da membrana, cuja absorbância a $565 \mathrm{~nm}$ se reduz devido à oclusão, e medidas de ângulo de contato, que informam sobre efeitos da membrana sobre a molhabilidade da superfície plana de óxido de silício. Assim podemos inferir sobre o tipo de estrutura que é adsorvida na superfície, e sob quais condições é possível obter deposição de bicamada sobre a superfície.

\section{I.2 Auto - associação de moléculas anfifílicas}

\section{I.2.1 Tipos de anfifilicos.}

O processo de auto-associação ocorre com estruturas moleculares anfifilicas, ou seja, moléculas que apresentam duas regiões distintas, uma porção hidrofóbica, composta por uma ou mais cadeias hidrocarbônicas saturadas ou insaturadas, e uma porção hidrofílica, composta por um grupo polar [Kunitake, 1995]. A figura I.2.1.1 mostra as estruturas de três anfifílicos de cadeia dupla que são capazes de se auto-associarem formando bicamadas. 
DPPC<smiles>CCCCCCCCCCCCCCCCCCCCCCC(=O)OCC(C)OC(=O)CCCCCCCC</smiles>

DODAB<smiles>CCCCCCCCCCCCCCCCCCCCCCCCCCCCCCCCCCCCCCC</smiles><smiles>CCCCCCCCCCCCCCCCCCCCCCCCCCOP(=O)(O[NH3+])OCCCCCCCC</smiles>

Figura I.2.1.1 - Estruturas de três anfifilicos capazes de se auto-associarem em forma de bicamadas: dipalmitoilfosfatidilcolina (DPPC), brometo de dioctadecildimetilamônio (DODAB) e dihexadecilfosfato (DHP). DODAB e DHP são anfifilicos sintéticos, enquanto DPPC é um fosfolipídio que ocorre em membranas celulares.

Os anfifilicos podem ser classificados como aniônicos, catiônicos, nãoiônicos ou zwiteriônicos. Esta classificação é decorrente da natureza do grupo polar. A seguir são mostrados alguns desses anfifilicos.

\section{$\underline{\text { Surfactantes de cadeia simples }}$}

Aniônico $\quad \mathrm{C}_{12} \mathrm{H}_{25}-\mathrm{O}-\mathrm{SO}_{3}{ }^{-} \mathrm{Na}^{+}$Dodecilsulfato de sódio (SDS ou NaDS)
Aniônico
$\mathrm{C}_{18} \mathrm{H}_{37}-\mathrm{COO}^{-} \mathrm{H}^{+} \quad$ Ácido esteárico
Catiônico
$\mathrm{C}_{16} \mathrm{H}_{33}-\mathrm{N}^{+}-\left(\mathrm{CH}_{3}\right)_{3} \mathrm{Br}$
Brometo de hexadeciltrimetilamônio (HTAB ou CTAB)

Não-iônico $\quad \mathrm{C}_{12} \mathrm{H}_{25}-\left(\mathrm{O}-\mathrm{CH}_{2}-\mathrm{CH}_{2}\right)_{5}-$ Monoéter de dodecilpentoxietileno $\left(\mathrm{C}_{12} \mathrm{E}_{5}\right)$

Zwiteriônico Lecitina de cadeia simples (Veja abaixo) Lisolecitina 


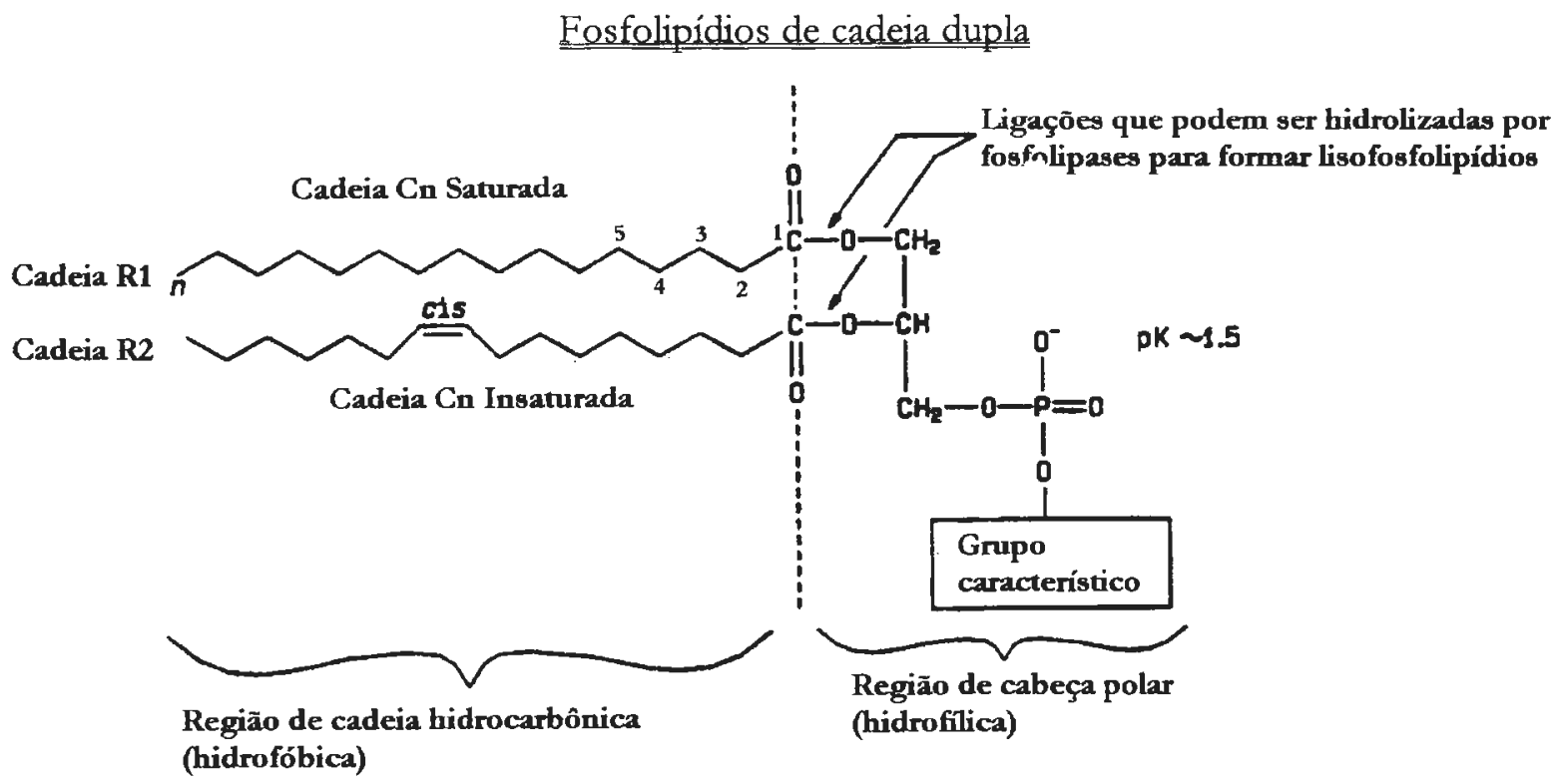

Cadeia hidrocarbônica $^{a} \quad$ Nome do fosfolipídio ${ }^{\mathrm{b}}$

Grupo característico $^{\mathrm{c}}$

Normalmente contem

16 - 18 carbonos por cadeia, a cadeia $\mathrm{R}_{2}$ ... ácido fosfatídico (aniônico)

$-\mathrm{H} \quad \mathrm{pK} \sim 11$

contem $1-3$ cis

$\mathrm{diC}_{12}:$ dilauroil... ...fosfatidilcolina ou lecitina (zwiteriônico)

$-\mathrm{CH}_{2}-\mathrm{CH}_{2}-\mathrm{N}^{+}\left(\mathrm{CH}_{3}\right)_{3}$

$\operatorname{diC}_{14}:$ dimiristoil... ...fosfatidiletanolamina (zwiteriônico)

$-\mathrm{CH}_{2}-\mathrm{CH}_{2}-\mathrm{NH}_{3}^{+}$

$\operatorname{diC}_{16}:$ dipalmitoil...

...fosfatidilglicerol (aniônico)<smiles>CCC(O)CO</smiles>

$\mathrm{diC}_{18}:$ distearoil... ...fosfatidilserina (aniônico)<smiles>CCC([NH3+])C(=O)[O-]</smiles>

Outros surfactantes e lipidios de cadeia dupla

dihexadecildimetilamônio

Aerosol OT

$$
\mathrm{C}_{16} \mathrm{H}_{33}^{\mathrm{C}_{16} \mathrm{H}_{33}} \mathrm{~N}^{+}\left(\mathrm{CH}_{3}\right)_{2} \mathrm{Br}^{-}
$$

$\mathrm{C}_{4} \mathrm{H}_{3}-\mathrm{CH}\left(\mathrm{C}_{2} \mathrm{H}_{5}\right)-\mathrm{CH}_{2}-\mathrm{COO}-\mathrm{CH}_{2}$ $\mathrm{C}_{4} \mathrm{H}_{9}-\mathrm{CH}\left(\mathrm{C}_{2} \mathrm{H}_{5}\right)-\mathrm{CH}_{2}-\mathrm{COO}-\mathrm{CH}$

$\mathrm{SO}_{3}{ }^{-} \mathrm{Na}^{+}$ 


$$
\text { monogalactosildiglicerídio (MGDG) }
$$

${ }^{a}$ Cerca de $50 \%$ dos lipídios possuem uma cadeia insaturada; essas aumentam a fluidez e hidrofobicidade da bicamada.

b Fosfatidilcolinas e fosfatidiletanolaminas são os dois principais lipídios encontrados em membranas animais, enquanto os galactolipídios DGDG e MGDG são os principais constituintes da membrana tilacóide de plantas. Note que nenhum desses possuem carga líquida em $\mathrm{pH}$ neutro.

c $\mathrm{O}$ estado iônico das cabeças polares é dado para dispersão aquosa em $\mathrm{pH} 7,4 . \mathrm{A} \mathrm{pH}$ alto $(>11.5)$ fosfatidiletanolamina torna-se negativamente carregada, enquanto em $\mathrm{pH}$ baixo $(<1)$ ela se torna positivamente carregada [Israelachvili, 1992].

É essencialmente o balanço entre as partes hidrofóbica e hidrofílica da molécula que fornece as propriedades especiais relacionadas à interação das mesmas com superfícies, o que leva a denominar tais sistemas de agentes ativos de superfície, ou simplesmente surfactantes [Ottewill, 1984].

\section{I.2.2 Fatores que determinam a auto-associação de anfifilicos}

As moléculas anfifilicas quando em solução aquosa se auto-associam dando origem a diferentes estruturas como, micelas esféricas, micelas cilíndricas, bicamadas, vesículas, entre outras formas possíveis. Os principais fatores que determinam a auto-associação são as forças de interação de van der Waals, efeito hidrofóbico, pontes de hidrogênio, interações eletrostáticas e o parâmetro geométrico, característico da molécula anfifílica [Israelachvili, 1992].

A figura 1.2.2.1 mostra algumas das estruturas formadas pela auto-associação de moléculas anfifilicas. 


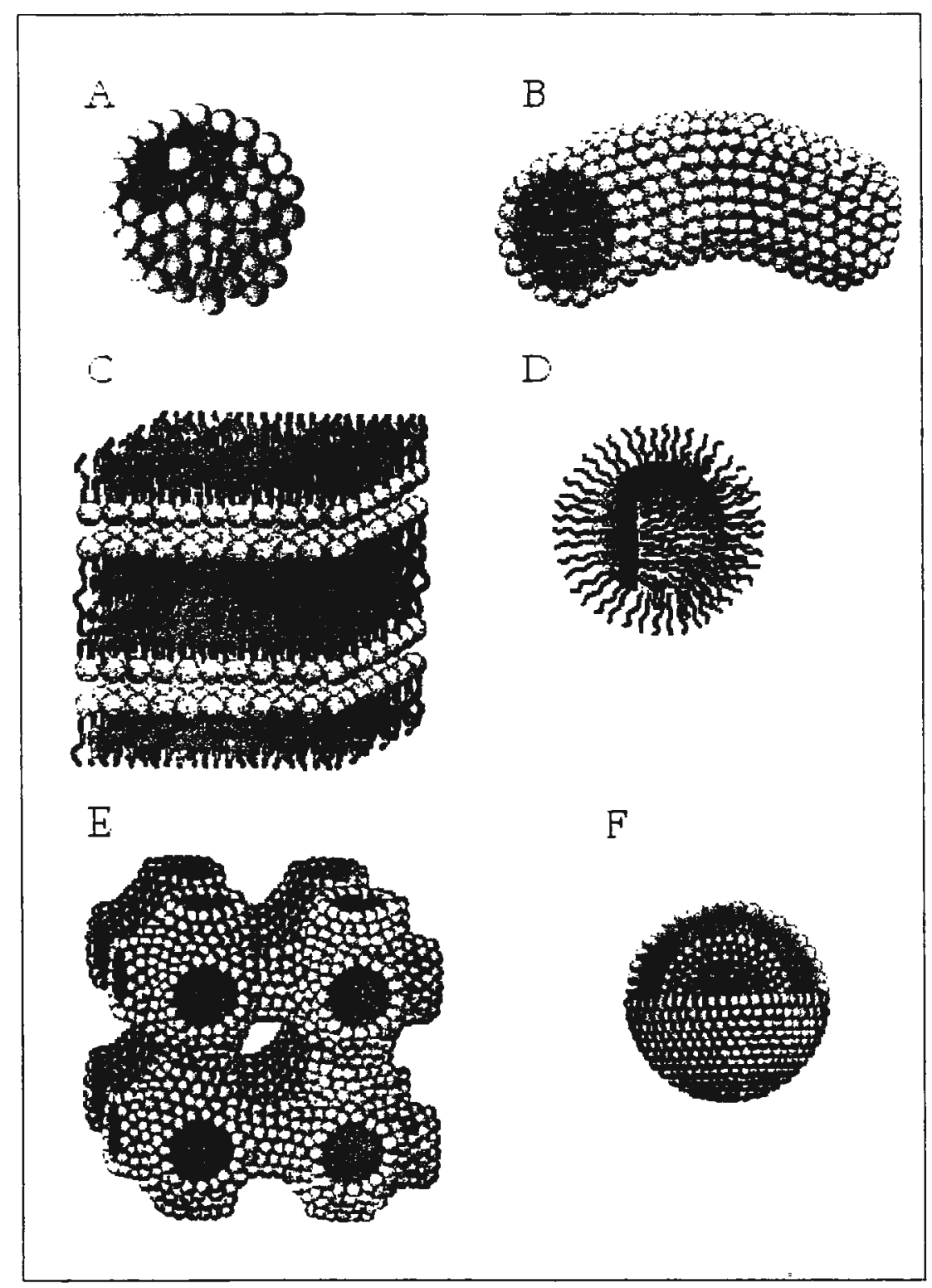

Figura I.2.2.1 - Auto-associação de anfifilicos gerando diferentes agregados supramoleculares. (A) Micela esférica; (B) micela cilíndrica; (C) bicamadas planas; (D) micela invertida; (E) estruturas bicontínuas e (F) vesícula [Evans e Wennerström, 1994].

A forma e tamanho do agregado podem mudar em resposta a variações da solução. Depende de fatores como composição, temperatura, força iônica e pH da solução [Gennis, 1989; Evans e Wennerström, 1994].

As dimensões dessas estruturas caem na faixa de partículas coloidais (1 nm $1 \mu \mathrm{m}$ ), essas partículas coloidais se formam por agregação de moléculas dispersas 
em um solvente polar (por exemplo a água) e possuem uma grande relação áreavolume (por exemplo, uma solução micelar típica, contendo $0,1 \mathrm{~mol} / \mathrm{L}$ tem uma área superficial entre a água e a micela de aproxiunadamente $4 \times 10^{4} \mathrm{~m}^{2}$ por litro de solução). Tais sistemas formam duas fases: a fase dispersa (colóide) e o meio da dispersão (solvente), separados por uma interface bem definida [Evans e Wennerström, 1994].

Exemplos de agregados supramoleculares são as membranas celulares, os modelos de membrana, as micelas, as fases hexagonais invertidas, as fases cúbicas, etc (figura I.2.2.1).

A principal força que dirige a formação e estabilização de agregados de anfifilicos em água é a interação hidrofóbica. $O$ efeito hidrofóbico é de natureza entrópica, permitindo uma maior organização das moléculas anfifilicas em forma de agregados, mas às custas de um aumento da entropia da água. Esta interação promove uma minimização do contato entre as cadeias hidrocarbônicas e a água (solvente).

Outros fatores, tais como forças de van der Waals, e pontes de hidrogênio, têm menor efeito estabilizante sobre o sistema quando comparados à interação hidrofóbica. A interação hidrofóbica é o principal fator de estabilização para virtualmente todas as estruturas biológicas macromoleculares e supramoleculares [Tanford, 1980].

O tamanho e forma do agregado de anfifilico são dependentes dos parâmetros moleculares (volume da porção hidrofóbica da molécula, comprimento de cadeia, e área da cabeça polar) e variáveis intensivas (temperatura e força iônica). O modelo de auto-associação de Israelachvili prevê o agregado ótimo para um determinado conjunto de parâmetros moleculares e variáveis intensivas usando um critério de minimização de energia livre para o monômero no agregado [Israelachivili et al., 1977]. 
Pode-se assumir que a energia livre de auto-associaçào de surfactantes em soluções diluídas é constituída de três termos [Evans e Wennerström, 1994].

- Uma favorável contribuição hidrofóbica, devido às cadeias hidrofóbicas isoladas no interior do agregado.

- Um termo de superfície, que reflete duas tendências opostas dos grupos polares: 1) a tendência de se aglomerarem para minimizar o contato entre cadeias hidrocarbônicas e água; 2) a tendência de se manterem separados, decorrente de repulsão eletrostática, repulsão de hidratação e impedimento estérico.

- Um termo de empacotamento, que no nível mais simples, requer que o interior hidrofóbico do agregado exclua água e cabeças polares.

Termos de superfície e empacotamento assumem diferentes formas funcionais para cada agregado geométrico específico. A forma que dá o mínimo de energia livre para um determinado conjunto de condições determina a estrutura ótima do agregado.

Para soluções diluídas em que interações entre agregados não são importantes, pode-se assumir essas concepções convenientemente no parâmetro de empacotamento crítico ou parâmetro geométrico $\left(N_{s}\right)$, que é dado por:

$$
N_{s}=\frac{v}{l a_{0}}
$$

onde, $v$ é o volume da porção hidrofóbica da molécula do surfactante; $l$ é o comprimento da cadeia hidrocarbônica e $a_{0}$ é a área ótima da cabeça polar.

A tabela I.2.2.1 ilustra a associação entre o parâmetro geométrico e os agregados supramoleculares formados. À medida que o parâmetro geométrico aumenta, a estrutura supramolecular formada também aumenta. 
Tabela I.2.2.1 - Forma de empacotamento de lipídios e estruturas formadas por esses lipídios [Israelachvili, 1992].

\begin{tabular}{|c|c|c|c|}
\hline Lipídio & $\begin{array}{l}\text { Parâmetro } \\
\text { geométrico } \\
\left(v / a_{0} l\right)\end{array}$ & $\begin{array}{l}\text { Forma de } \\
\text { empacotamento } \\
\text { crítico }\end{array}$ & Estrutura formada \\
\hline $\begin{array}{l}\text { Lipídios de cadeia simples (surfactantes) } \\
\text { com área da cabeça polar grande: } \\
\text { SDS em baixa concentraf̧ão de sal }\end{array}$ & $<1 / 3$ & $\frac{8^{\text {Cone }}}{1 .}$ & Micela esférica \\
\hline $\begin{array}{l}\text { Lipídio de cadeia simples com área de } \\
\text { cabeça polar pequena: } \\
\text { SDS e CTAB em alta concentração de sal, liṕídios } \\
\text { não iônicos. }\end{array}$ & $1 / 3-1 / 2$ & Tronco de cone & 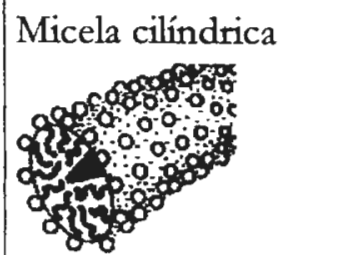 \\
\hline $\begin{array}{l}\text { Lipídios de cadeia dupla com área de cabeça } \\
\text { polar grande, cadeias fluidas: } \\
\text { Fosfatidilicolina (lecitina), fosfatidilserina, } \\
\text { fosfatidilglicernl, fosfatidilinositol, ácido fosfatílico, } \\
\text { esfingomielina, diexadecilfosfato, sais de } \\
\text { dialquildimetilamônio. }\end{array}$ & $1 / 2-1$ & Tronco de cone & 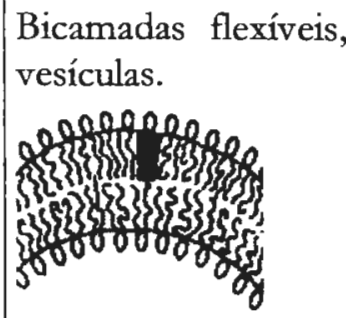 \\
\hline $\begin{array}{l}\text { Lipídios de dupla cadeia com área de cabeça } \\
\text { polar pequena, lipídios aniônicos em alta } \\
\text { concentração salina, cadeias saturadas } \\
\text { rígidas: } \\
\text { Fosfatidiletanolamina, fosfatidil serina }+\mathrm{Ca}^{2+}\end{array}$ & $\sim 1$ & $\begin{array}{l}\text { Cilindro } \\
\text { Pa }\end{array}$ & 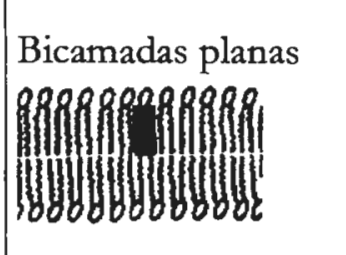 \\
\hline $\begin{array}{l}\text { Lipídio de dupla cadeia com área de cabeça } \\
\text { polar pequena, lipídios não iônicos, cadeias } \\
\text { poli (cis) insaturadas: } \\
\text { Fosfatidiletanolamina insaturada, cardiolïpina }+ \\
C^{2+} \text {, ácido fosfatidico }+\mathrm{Ca}^{+} \text {, colesterol. }\end{array}$ & $>1$ & $\begin{array}{l}\text { Tronco de cone } \\
\text { invertido ou } \\
\text { cunha }\end{array}$ & Micelas invertidas \\
\hline
\end{tabular}

Vesículas grandes de DHP preparadas em uma dada força iônica $(16 \mathrm{mM}$ de $\mathrm{NaCl}$, mas em diferentes valores de $\mathrm{pH}$ possuem tamanhos diferentes. São menores para os maiores valores de $\mathrm{pH}$. $\mathrm{O}$ aumento do $\mathrm{pH}$ promove uma maior dissociação do fosfato da cabeça polar do DHP, conseqüentemente ocorre uma maior repulsão eletrostática entre as cabeças polares, o que leva a um aumento da 
área ótima da cabeça polar. Assim, o parâmetro geométrico diminui, e conseqüentemente o tamanho do agregado também diminui [Carmona-Ribeiro e Hix, 1991].

Vesículas pequenas de cloreto de dioctadecildimetilamônio (DODAC) preparadas por sonicação fundem pela adição de sal, enquanto vesículas pequenas de DHP permanecem agregadas sem fundir. [Carmona-Ribeiro e Chaimovich, $1986]$.

Vesículas grandes de DODAB, DODAC e acetato de dioctadecildimetilamônio (DODAAc) aumentam de tamanho com o aumento da concentração salina da solução em que foram preparadas. Isso ocorre devido à blindagem da carga do anfífílico catiônico, o que diminui a repulsão eletrostática entre as cabeças polares, o que provoca a diminuição da área do monômero, fazendo aumentar o parâmetro geométrico dos anfifílicos e aumentando a tendência de formação de agregados maiores [Nascimento et al, 1998].

Variando-se a concentração salina de 0 a $10 \mathrm{mM}$ o parâmetro geométrico para moléculas de DODAC varia de 0,64 a 0,81 , mostrando a tendência de formação de agregados maiores [Carmona-Ribeiro, 1992 b].

Se o modelo da auto associação de Israechvili pode ser estendido à situação de adsorção sobre superfície sólida ainda é uma questão em aberto.

\section{I.2.3 - Anfifilicos formadores de bicamadas}

Bicamadas planares formadas por moléculas de anfifilicos têm uma posição central no estudo de auto-organização, apresentando papel crucial em processos biológicos e industriais [Evans e Wennerström, 1994]. Fosfolipídios são abundantes nas membranas biológicas, constituintes das paredes celulares. Eles derivam de um glicerol esterificado por dois ácidos graxos, enquanto um grupo polar é ligado ao terceiro $\mathrm{OH}$ do glicerol, constituindo um triacilglicerol. Nos mamíferos, esse terceiro grupo é fosforilado e então modificado, formando um fosfolipídio. $\mathrm{O}$ 
intervalo típico de comprimento de cadeia hidrocarbônica é de 16 a 18 carbonos e o grau de insaturação tende a aumentar com o aumento do comprimento da cadeia.

Lipídios que formam bicamadas são aqueles que não podem empacotar em estruturas micelares, devido à sua pequena área de grupos da cabeça polar $\left(a_{0}\right)$ ou por causa de sua cadeia hidrocarbônica muito volumosa para se ajustar em agregados micelares, enquanto mantêm uma área superficial ótima. Para lipídios formadores de bicamadas, o valor de $v / a_{0} l$ deve ser próximo de 1 , e para que isso ocorra é requerido que a área do grupo polar, $a_{0}$, e o comprimento da cadeia hidrocarbônica, $l$, sejam iguais, e o volume da cadeia hidrocarbônica, $v$, deve ser cerca de duas vezes aquela dos lipídios formadores de micela (para que $v / a_{0} l$ esteja entre $1 / 3$ e $1 / 2$ ). Por esta razão, lipídios com duas cadeias são prováveis formadores de bicamadas, e de fato a maioria deles forma bicamadas. Por exemplo, lisolecitinas formam micelas pequenas, mas não esféricas, enquanto lecitinas com duas cadeias alquilicas formam bicamadas.

A duplicação da cadeia também afeta outras propriedades do agregado, tanto estáticas como dinâmicas. Primeiro, aumenta a hidrofobicidade do lipídio, que diminui drasticamente sua concentração micelar crítica (CMC). A CMC de lipídios formadores de micelas é por volta de $10^{-2}$ a $10^{-5} \mathrm{M}$ enquanto a CMC de lipídios formadores de bicamadas está entre $10^{-6}$ e $10^{-10} \mathrm{M}$. Segundo, aumenta o tempo de residência, $\tau_{R}$, das moléculas dentro do agregado. Para lipídios formadores de micelas o tempo de residência é aproximadamente $10^{-4} \mathrm{~s}$, enquanto que para lipídios formadores de bicamadas este tempo é de aproximadamente $10^{+4} \mathrm{~s}$. [Israelachvili, 1992].

Em uma situação ideal, a bicamada se estenderia indefinidamente na direção lateral. $\mathrm{Na}$ realidade, amostras finitas, como fragmentos de membrana, mostram defeitos hidrofóbicos nas bordas, e bicamadas tendem a fechar sobre si mesmas, formando estruturas conhecidas como lipossomos [Evans e Wennerström, 1994]. 
Quando as cadeias alquilicas estão no estado gel, elas possuem uma área de seção transversal de aproximadamente $20 \AA^{2}$ por cadeia no plano perpendicular a direção da cadeia. Se a área dos grupos polares da bicamada emparelhar àquelas $\mathrm{da}(\mathrm{s})$ cadeia(s), a estrutura $L_{\beta}$ é adotada. No caso de um mau emparelhamento entre as áreas das cabeças polares e as áreas das cadeias hidrocarbônicas uma estrutura inclinada, como em $L_{\beta}$ ', ou uma estrutura ondulada, como em $\mathrm{P}_{\beta}$ ' podem aparecer (figura I.2.3.1). Para anfifílicos de dupla cadeia, as cadeias podem eventualmente interdigitar, fazendo com que a espessura da camada apolar seja igual ao comprimento da cadeia hidrocarbônica. A figura I.2.3.1 mostra esquematicamente as estruturas citadas acima.

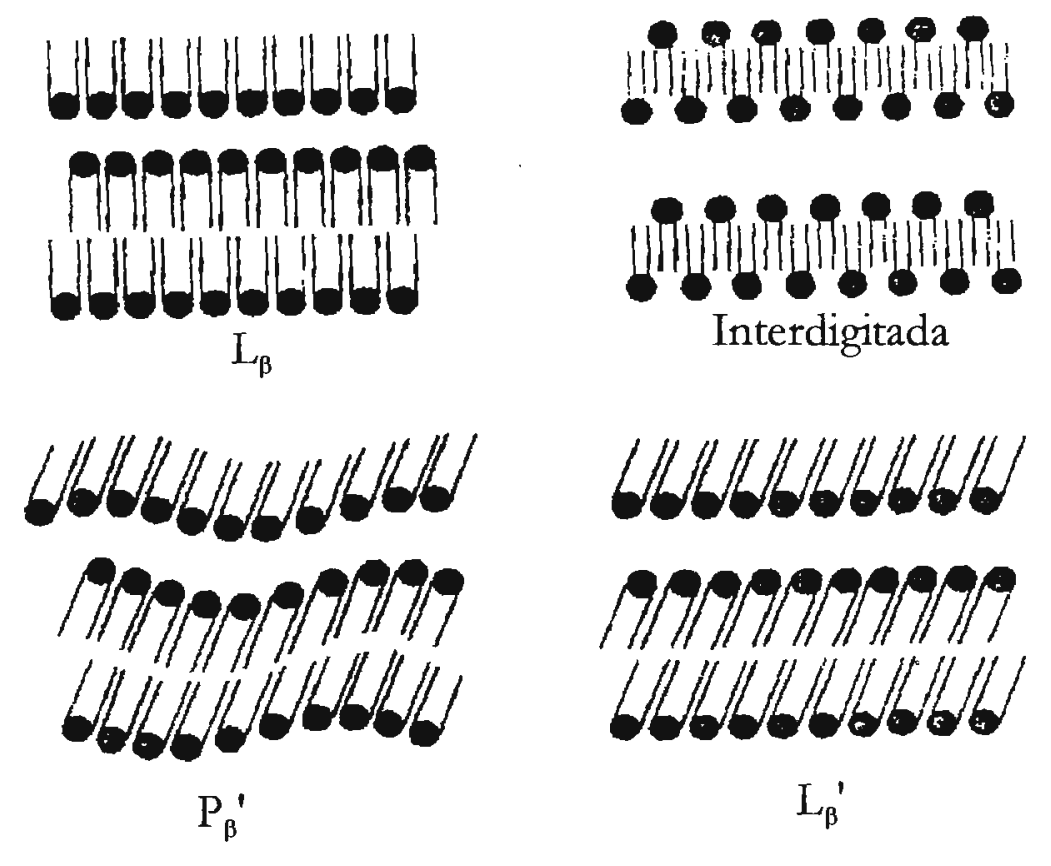

Figura I.2.3.1 - Estruturas que podem ser formadas por bicamadas na fase gel.

Vesículas são bicamadas fechadas que delimitam um compartimento aquoso interno e outro externo. São úteis como modelos de membrana. As vesículas, em sua maioria, são termodinamicamente instáveis.

As propriedades físicas e funcionais das dispersões de vesículas dependem do método de preparação [Evans e Wennerström, 1994]. 
Existem vários métodos de preparação de vesículas [New, 1994]. Como exemplos temos: 1 - sonicação em banho, que forma vesículas multilamelares [Kunitake et al., 1977]; 2 - sonıcação por tip, que forma vesículas unilamelares pequenas [Mortara et al., 1978; Kano et al., 1979] e/ou fragmentos de membrana [Pansu et al., 1990; Carmona-Ribeiro et al., 1991]; 3 - vaporização clorofórmica, que gera vesículas unilamelares grandes [Carmona-Ribeiro e Chaimovich, 1983; Carmona-Ribeiro et al., 1984]; 4 - injeção etanólica seguida de diálise para eliminar o etanol, este método forma vesículas unilamelares pequenas [Batzri e Korn, 1973; Kremer et al, 1977]; 5 - injeção etérea, que forma vesículas unilamelares grandes [Deamer e Bangham, 1976].

O volume capturado por uma vesícula é definido como o volume englobado por mol de anfifílico e expresso em litros por $\mathrm{mol}(\mathrm{L} / \mathrm{mol})$. Esse parâmetro cresce com o diâmetro da vesícula [Carmona-Ribeiro, 1992a]. O volume capturado para dispersões de vesículas de DODAC sonicadas em água é próximo de zero $(0,13$ $\mathrm{L} / \mathrm{mol})$ e menor que a dispersão equivalente de fosfolipídios $(0,5-0,8 \mathrm{~L} / \mathrm{mol})$. O volume capturado de vesículas grandes de DODAC e DHP, obtidas por vaporização cloroformica é 9,7 e 13,6 L/mol, respectivamente, e é comparável àquele de vesículas unilamelares grandes de fosfolipídeos obtidos por vaporização em fase reversa, 11,7 L/mol [Carmona-Ribeiro, $1992 \mathrm{~b}$ ].

O tamanho das vesículas pode ser determinado por microscopia eletrônica ou por espectroscopia de correlação fotônica. Depois de sonicadas (10 minutos para DODAC e 20 minutos para DHP) as dispersões são compostas de vesículas não esféricas de cerca de 45 e $59 \mathrm{~nm}$ de raio hidrodinâmico, respectivamente. As dispersões de DODAC e DHP obtidas por vaporização cloroformica em água são compostas por vesículas esféricas de cerca de 120 e $185 \mathrm{~nm}$ de raio hidrodimânico, respectivamente. A relação entre o raio hidrodinâmico e o raio de uma esfera com o peso molecular de uma vesícula sonicada é perto de 3 , indicando um pronunciado desvio da forma esférica [Carmona-Ribeiro, 1992 b]. 
À temperatura ambiente, bicamadas de DODAC e DHP estão no estado gelrígido. A liberdade rotacional das cadeias hidrocarbônicas aumenta com o aumento da temperatura. A transição da fase gel para o estadu fluido líquido-cristalino corresponde a uma abrupta diminuição na densidade de empacotamento a uma temperatura particular, a temperatura de transição de fase (Tc). Quanto maior a densidade de empacotamento das cadeias hidrocarbônicas no estado gel, maior é a Tc. Valores de Tc medidos para vesículas de DODAC estão a cerca de $38^{\circ} \mathrm{C}$, enquanto que aqueles medidos para vesículas de DHP variam entre 57 e $72{ }^{\circ} \mathrm{C}$, dependendo do $\mathrm{pH}$.

Estudos de permeabilidade de dispersões de fosfolipídio mostraram que etilenoglicol, metilureia e etilureia parecem permear a membrana tão rápido quanto a água; uréia, propionamida e glicerol permeiam um pouco mais lentamente e malonamida e eritritol mais lentamente ainda. Acetato de amônio permeia quase tão rápido quanto a água, enquanto acetato de sódio é muito menos permeante. De modo geral, há baixa permeabilidade a cátions monovalentes [Bangham et al, 1967].

Em pesquisa e aplicações de lipossomos o termo estabilidade é usado vagamente e não é freqüentemente bem definido. A definição geral de estabilidade contem vários aspectos que podem ser definidos separadamente, mas freqüentemente agem sinergicamente. A estabilidade física é o aspecto que envolve preservação da estrutura e volume interno do lipossomo, é a estabilidade de tamanho e forma do lipossomo. Tanto preservação do tamanho, assim como encapsulação depende das propriedades mecânicas da bicamada e termodinâmicas dos sistemas. Vesículas são termodinamicamente instáveis porque a membrana é simetricamente curvada, e a baixa energia de conformação das membranas é, em geral, planar [Lasic, 1994].

Os mecanismos de degradação de lipídios mais comuns são a oxidação e a hidrólise. Em geral, a cabeça polar é muito mais estável que a cadeia hidrocarbônica. As cadeias hidrocarbônicas insaturadas são objetos de oxidação. 
Oxidação é uma reação radicalar que em último caso resulta na quebra das cadeias ou, em caso de duplas ligações adjacentes, formação de peróxidos cíclicos [Lasic, 1994].

Agregação é o primeiro passo na fusão de vesículas e depende da estabilidade termodinâmica da amostra e da presença de substâncias fusogênicas. Fusão é praticamente um processo irreversível enquanto agregação pode ser reversível. Há muitas forças atrativas e repulsivas que agem entre partículas coloidais. A força de atração de van der Waals age entre todas as partículas separadas por um meio com propriedades de polarização diferentes. Partículas que possuem a mesma carga experimentam uma repulsão eletrostática. Essas duas forças são a base da teoria de DLVO (DLVO = Dejarguin, Landau, Verwey, Overbeek) da estabilidade de partículas coloidais. Em muitos casos, no entanto, essa teoria pode não predizer a estabilidade de liposomos. Para elucidar por que suspensões coloidais têm uma menor estabilidade que a esperada, forças atrativas adicionais entre as partículas coloidais, como a atração hidrofóbica ou atração correlação íon-íon foram introduzidas [Helm et al, 1989; Carmona-Ribeiro, 1992a; Jeon et al, 1991]. A origem de algumas dessas forças não é ainda bem conhecida, e são ainda controversas. Por exemplo, a força de hidratação como sendo repulsiva foi questionada e uma força repulsiva de protusão, uma repúlsão estérica causada pelo movimento vertical das cabeças polares foi proposta [Israelachvili $\mathrm{e}$ Wennerström, 1990]. A situação é ainda menos clara com respeito à força atrativa hidrofóbica entre dois liposomos. Qualitativamente, no entanto, essa atração pode ser explicada como uma conseqüência da perturbação da estrutura da água.

Essas forças suprem uma base para explicar a estabilidade de liposomos. Predominantemente, densidade superficial de carga, potencial zeta, distribuição de tamanho e homogeneidade, assim como, força iônica e $\mathrm{pH}$ do meio determinam a estabilidade coloidal in vitro [Lasic, 1994]. 


\section{I.3 - Superfícies de $\mathrm{SiO}_{2}$}

$\mathrm{O}$ dióxido de silício ou simplesmente óxido de silício $\left(\mathrm{SiO}_{2}\right)$ pode-se apresentar tanto no estado cristalino quanto no estado amorfo.

No estado cristalino, forma uma rede tridimensional, estável e não volátil.

$\mathrm{O} \mathrm{SiO}_{2}$ ocorre em diferentes formas cristalinas, mas todas possuem átomos de silício ligados a quatro átomos de oxigênio por meio de uma ligação simples SiO (figura I.3.1).

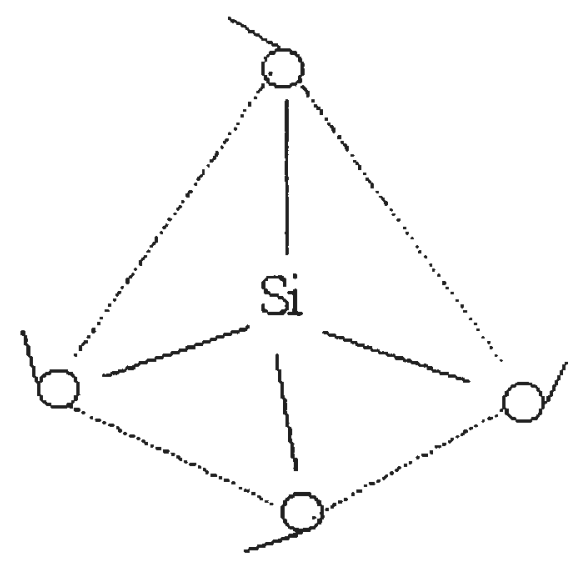

Figura I.3.1 - Esquema das ligações entre silício e oxigênio.

De todas as ligações que o silício forma, a ligação Si-O tem uma energia de ligação maior que qualquer outra, com exceção da ligação Si-F. Não é surpreendente então que a química do silício seja dominada por compostos contendo ligações $\mathrm{Si}-\mathrm{O}$, e que o $\mathrm{SiO}_{2}$ seja uma substância quimicamente estável. O óxido de silício constitui aproximadamente $55 \%$ da superfície terrestre e é encontrado em todas as plantas e animais. $\mathrm{O}$ óxido de silício ocorre em muitas formas na natureza, entre elas estão a areia, o sílex (pedra de isqueiro), ágata, jaspe, ônix e quartzo [Mortmer, 1971].

As modificações de $\mathrm{SiO}_{2}$, que para a maior parte também ocorre na natureza, são mostradas na tabela I.3.1. 
Tabela I.3.1 - Modificações de óxido de silício

\begin{tabular}{ll}
\hline \multicolumn{2}{l}{ Estado cristalino } \\
\hline Quartzo & Modificação mais difundida, cristal, areia de quartzo. \\
Tridimita & Forma em altas temperaturas \\
Cristobalita & Forma em altas temperaturas \\
Coesita & Modificação em altas pressões, muito rara na natureza. \\
Queatita & Modificação que pode ser sinteticamente produzida \\
Estichovita & Modificação em altas pressões, muito rara na natureza. \\
\hline Estado amorfo & \\
\hline Lechatelierita & ${\text { Vidro de } \mathrm{SiO}_{2} \text { natural, formado por fusão induzida por descarga }}$ \\
Opalas & $\mathrm{SiO}_{2}$ não puro, contêm água. \\
Kieselguhr & $\mathrm{SiO}_{2}$ extraído de terras infusórias pré-históricas e diatomácias, \\
& sempre contaminado. \\
Silica vítrea & "Vidro de sílica" produzido sinteticamente, vidro de $\mathrm{SiO}_{2}$ puro. \\
\hline
\end{tabular}

Dentre as formas apresentadas acima, o quartzo é a mais estável termodinamicamente. Não há transformação da tridimita ou cristobalita em quartzo, pois o processo de migração de átomos no sólido requer energias de ativação muito altas [Liptrot, 1989].

O óxido de silício amorfo abrange desde as partículas coloidais até os géis macroscópicos. Os particulados possuem grande área específica, sendo que suas propriedades dependem da química de superfície de sua fase sólida. São usados como catalisadores, para processamento mineral, como cerâmicas e adsorbentes, e ainda, para fabricação de agentes espessantes em sistemas orgânicos, como tintas, elastômeros, e graxas lubrificantes.

Dois grupos funcionais podem ser encontrados em superfícies de sillica: os silanóis e os siloxanos (figura I.3.2). 

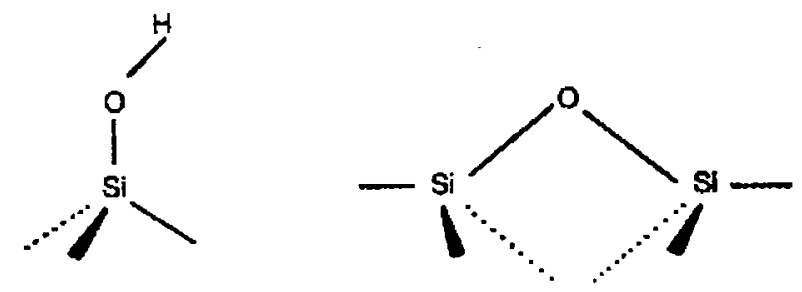

Figura I.3.2 - Grupo silanol (esquerda) e siloxano (direita) encontrados na superfície de sílica.

Um caracter hidrofilico deve ser atribuído aos grupos silanóis, isto é, esses grupos atraem água e são responsáveis pelo fato de sílica hidrofilica ser facilmente molhada pela água. Além disso, a reatividade química dos silanóis permite obter silica hidrofóbica (ver figuras I.3.1.1.2 e I.3.1.1.3).

Em contraste, os grupos siloxanos são quimicamente inertes.

Com base nesses dois grupos funcionais, podem ser distinguidos os seguintes grupos:

- Grupos silanóis livres

- Pontes de grupos silanóis

- Grupos silanóis geminais

- Grupos silanóis vicinais

- Grupos siloxanos.

Esses grupos estão esquematicamente representados na figura I.3.3. 


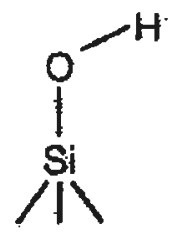

Livre

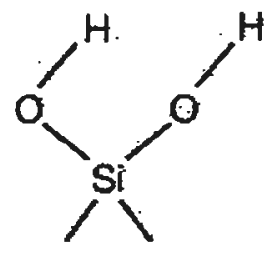

Geminal

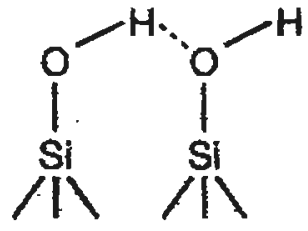

Vicinal e ponte

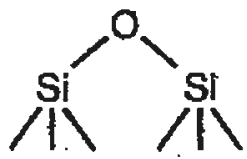

Siloxano

Figura I.3.3 - Grupos encontrados na superfície de $\mathrm{SiO}_{2}$.

\section{I.3.1 - Particulados}

Particulados de sillica podem ser obtidos por diversos modos, entre eles estão o "arco silica", onde a sillica é produzida por redução da areia de quartzo com coque em um forno arco elétrico e subseqüente oxidação do $\mathrm{SiO}$ formado; "processo de plasma", onde a sillica é formada por meio de gases ionizados; "Sílica precipitada", silica que desenvolve durante a conversão de vidro de silício com ácido sulfúrico; e "AEROSIL", onde a silica é produzida por processo de hidrólise em altas temperaturas. Os dois primeiros métodos de preparação não têm importância técnica, quando comparados com os dois outros métodos [DEGUSSA, 1993].

O "processo AEROSIL", isto é, a síntese industrial em larga escala de AEROSIL, pode ser descrito como uma hidrólise em chama contínua de tretracloreto de silício $\left(\mathrm{SiCl}_{4}\right)$. Durante esse processo, $\mathrm{SiCl}_{4}$ é convertido a fase gasosa, em temperaturas de aproximadamente $1000^{\circ} \mathrm{C}$, e então reage espontânea e quantitativamente em uma chama de oxihidrogênio, formando água intermediariamente e produzindo o dióxido de silício desejado. 


$$
\begin{aligned}
& 2 \mathrm{H}_{2}+\mathrm{O}_{2} \longrightarrow \mathrm{H}_{2} \mathrm{O} \\
& \mathrm{SiCl}_{4}+2 \mathrm{H}_{2} \mathrm{O} \longrightarrow \mathrm{SiO}_{2}+4 \mathrm{HCl} \\
& 2 \mathrm{H}_{2}+\mathrm{O}_{2}+\mathrm{SiCl} \longrightarrow \mathrm{SiO}_{2}+4 \mathrm{HCl}
\end{aligned}
$$

$\mathrm{O}$ único subproduto é cloreto de hidrogênio gasoso que é separado do material AEROSIL sólido.

As figuras I.3.1.1 e I.3.1.2 mostram esquematicamente a chama do AEROSIL e a produção de AEROSIL, respectivamente.

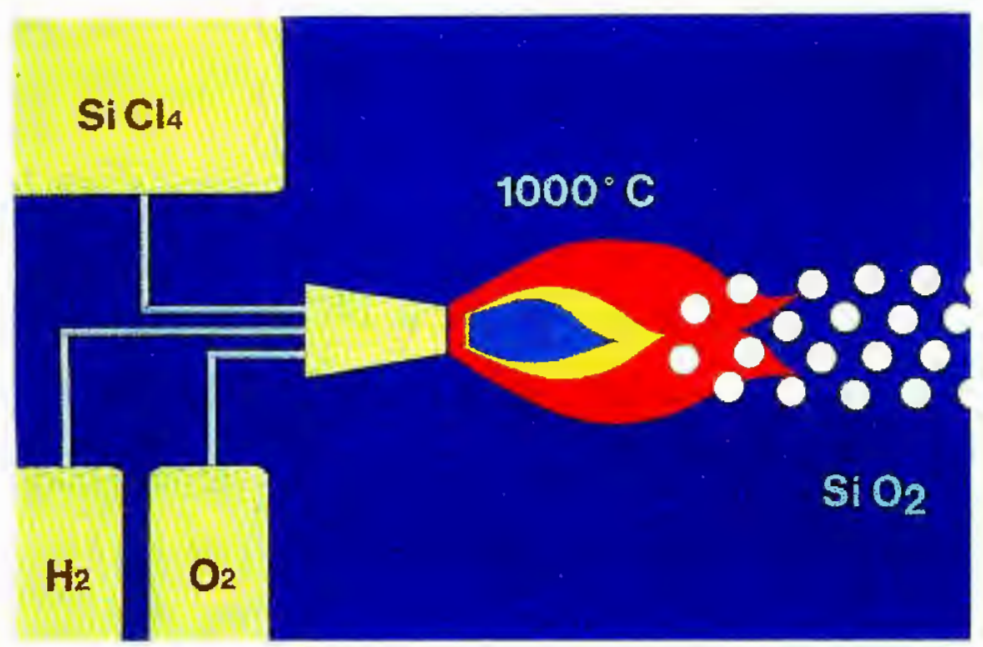

Figura I.3.1.1 - Chama AEROSIL (esquema)

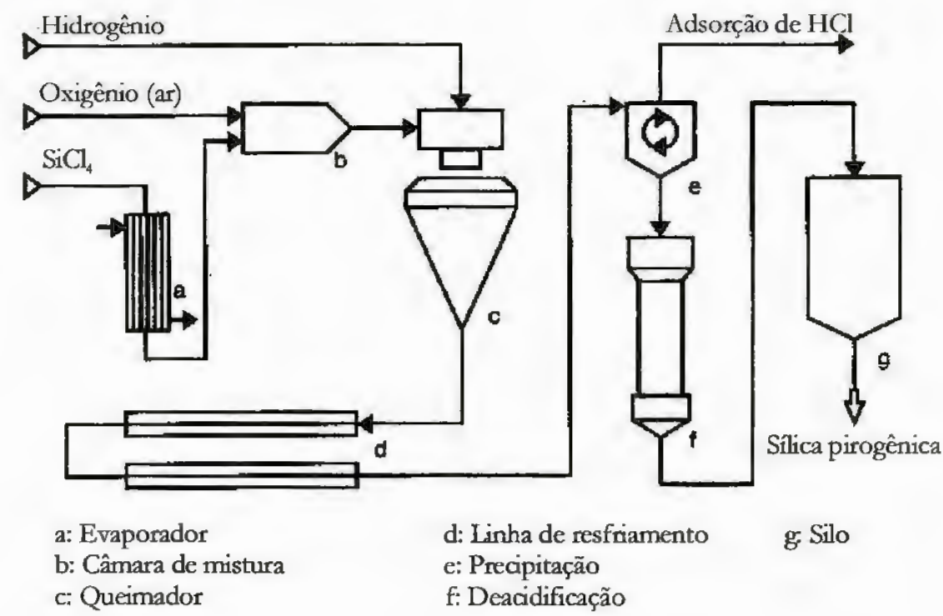

Figura I.3.1.2 - Esquema de produção de AEROSIL 
Variando a concentração dos teagentes, a temperatura da chama, e o tempo de residência da sílica na câmara de combustão, é possível variar o tamanho das partículas, a distribuição de tamanho das partículas, a área superficial específica e as propriedades das superfícies da sílica dentro de limites amplos.

Ao invés de tetracloreto de silício, silanos como metiltriclorosilano, triclorosilano, etc. podem ser usados como matéria prima, sozinho ou em misturas com $\mathrm{SiCl}_{4}$. As condições relativas a aquecimento e fluxo devem ser variadas em comparação com aquelas usadas para tetracloreto de silício para obter o mesmo produto final [DEGUSSA S/A, 1993].

\section{I.3.1.1 - Tipos de silica}

Silica pirogênica no final do processo possui em sua superfície grupos silanóis, que the confere características hidrofilicas. A figura I.3.1.1.1 mostra a dissociação dos grupos silanóis da superfície da sílica.

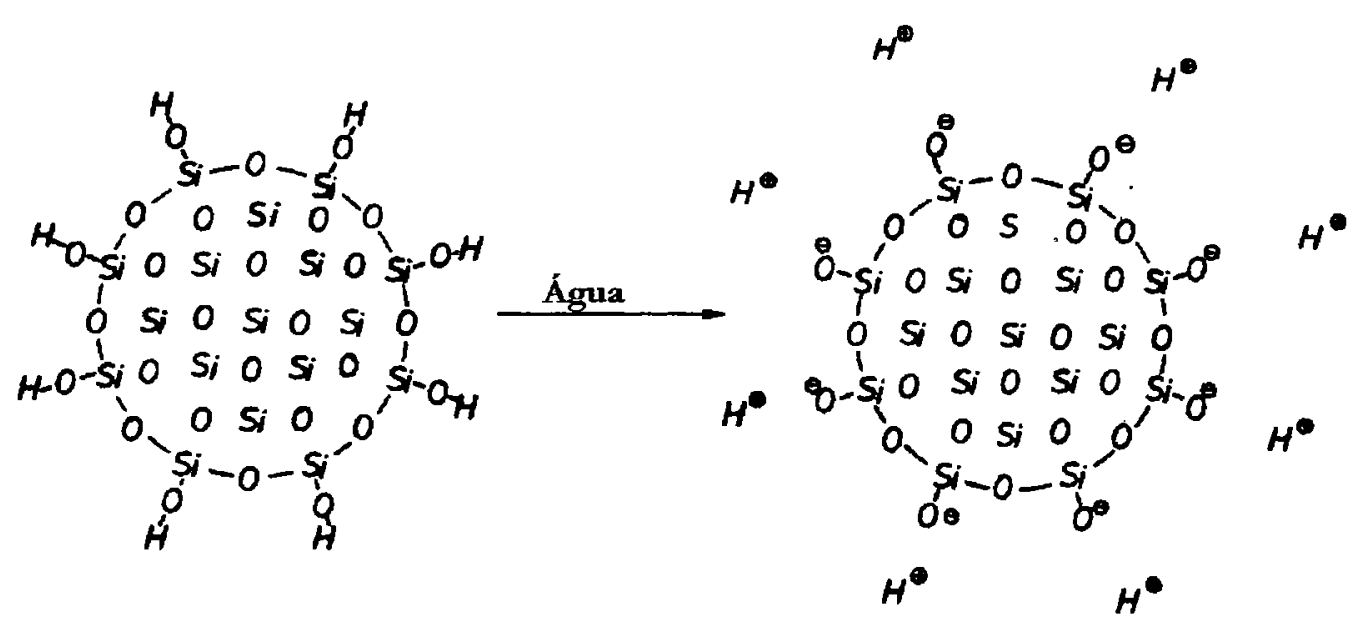

Figura 1.3.1.1.1 - Dissociação dos grupos silanóis da superfície da silica (representação esquemática). 
Os valores $\mathrm{pKa}$ da sillica pode variar com o tipo de silica. Sílica gel por exemplo tem $\mathrm{pKa}$ igual a 7,7, enquanto que silica coloidal tem pKa igual a 8,2 e silica pirogênica, 7,2 [Milonjić, 1987].

O ponto de carga zero da sillica se situa em pH 2,5 [Tadros e Lyklema, 1968].

A sílica hidrofilica pode passar por um processo de silanização, resultando em uma funcionalização homogênea e efetiva da superfície da sílica. $\mathrm{Na}$ figura I.3.1.1.2 é mostrado um esquema desta silanização.
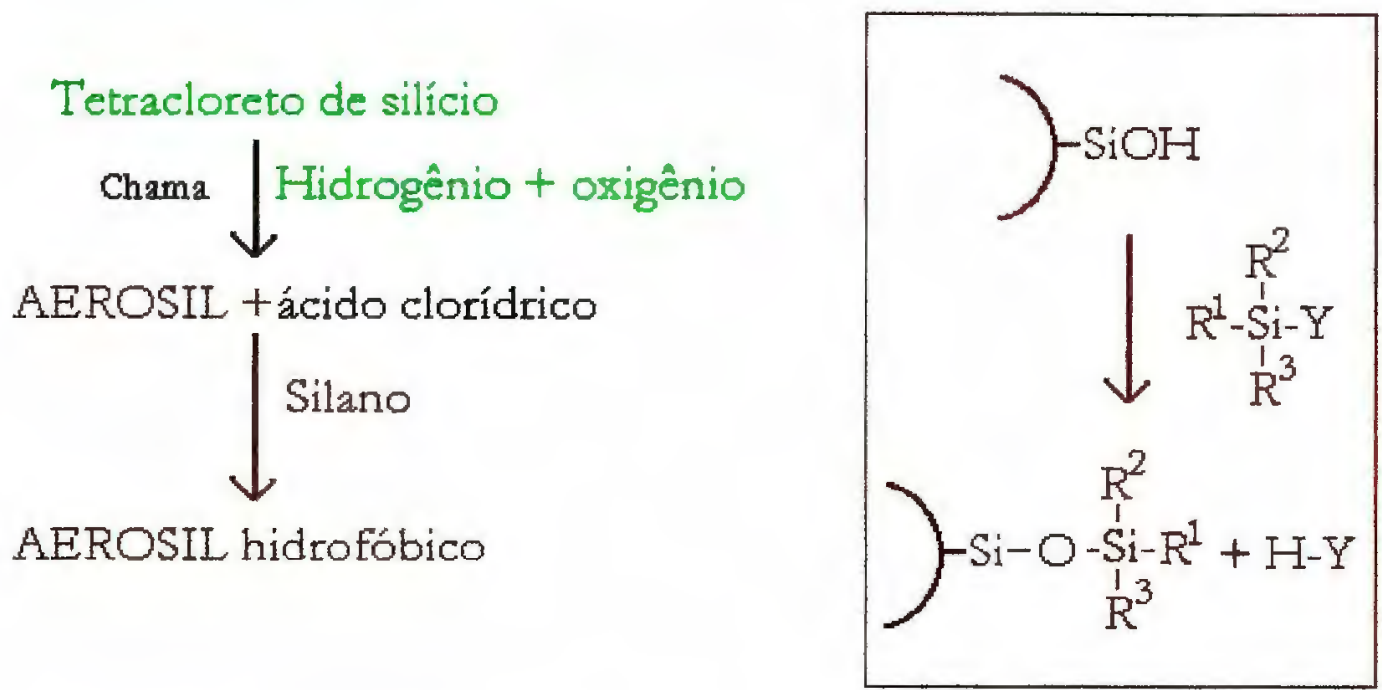

Figura I.3.1.1.2 - Esquema de silanização de sílica hidrofilica

A funcionalização da superfície de AEROSIL é feita com halogênosilano, alquilsilanos, siloxanos, etc. A figura I.3.1.1.3 mostra os grupos superficiais encontrados em alguns tipos de sílica hidrofóbica. 
<smiles>C[Si](C)([O-])[O-]</smiles><smiles>C[Sn](C)(C)[O-]</smiles><smiles>[10BH2][Si]([O])([O-])[O-]</smiles><smiles>C[Si](C)(C)O</smiles>

Figura I.3.1.1.3 - Alguns grupos funcionais de superfícies de sílica hidrofóbica.

\subsubsection{2 - Caracterização de particulados}

Sílicas sintéticas podem ser caracterizadas por uma quantidade de parâmetros físicos e químicos. Os parâmetros mais importantes estão relacionados na tabela I.3.1.2.1.

Tabela I.3.1.2.1 - Alguns parâmetros físicos e químicos que caracterizam as sílicas sintéticas.

\begin{tabular}{|l|l|}
\hline & Dimensão \\
\hline Densidade aparente & {$[\mathrm{g} / \mathrm{mL}]$} \\
\hline Densidade aparente compactado e volume compactado & $\begin{array}{l}{[\mathrm{g} / \mathrm{mL}]} \\
{[\mathrm{mL} / 100 \mathrm{~g}]}\end{array}$ \\
\hline Densidade & {$\left[\mathrm{g} / \mathrm{cm}^{3}\right]$} \\
\hline Quantidade de umidade & {$[\%]$} \\
\hline Tamanho primário de partícula & {$[\mathrm{nm}]$} \\
\hline Tamanho de aglomerado & {$[\mu \mathrm{m}]$} \\
\hline Área superficial específica & {$\left[\mathrm{m}^{2} / \mathrm{g}\right]$} \\
\hline pH & \\
\hline Condutividade elétrica & {$[\mu \mathrm{S} / \mathrm{cm}]$} \\
\hline Conteúdo de $\mathrm{SiO}_{2}$ & {$[\%]$} \\
\hline
\end{tabular}


O tamanho de partícula e distribuição de tamanho de sillicas sintéticas são quase que exclusivamente determinadas por microscopia eletrônica.

Para determinar o aglomerado ou tamanho da partícula aglomerada, para sílica em pó, assim como embebida em um meio, há diferentes métodos para avaliar, como microscopia óptica e eletrônica e análises de sedimentação.

A área superficial específica é geralmente medida pelo método de BET (Brunauer, Emmett e Teller) [Brunauer et al., 1938]. Neste processo, um gás usualmente nitrogênio - é adsorvido a uma superfície de sílica a baixas temperaturas, pelo que as proporções de gás adsorvido pelas superfícies internas e externas são combinadas na medida [DEGUSSA S/A, 1986]. A área superficial específica também pode ser determinada por titulação potenciométrica [Sears, 1956].

A densidade de carga da superfície de sílica em determinado meio pode ser obtido attavés de titulação potenciométrica [Tadros e Lyklema, 1968; Milonjić, 1987]. A figura I.3.1.2.2 mostra como varia a densidade de carga em função do $\mathrm{pH}$ para $\mathrm{SiO}_{2}$ em quatro concentrações diferentes de $\mathrm{KCl}$. 


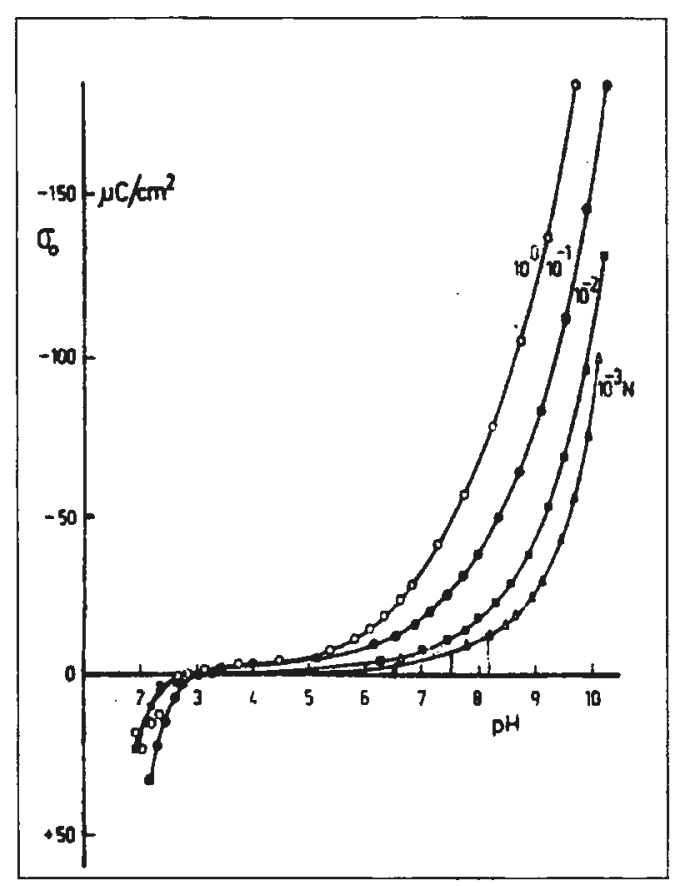

Figura I.3.1.2.1 - Densidade superficial de carga em função do pH para $\mathrm{SiO}_{2}$ em 4 diferentes concentrações de KCl [Tadros e Lyklema, 1968].

\section{I.3.1.3 - AEROSIL OX-50}

A sílica utilizada neste trabalho foi a AEROSIL OX-50, produzida pela DEGUSSA S/A. Esta silica possui caráter hidrofilico. Com área superficial, obtida pelo método de $\mathrm{BET}$, de $50 \pm 15 \mathrm{~m}^{2} / \mathrm{g}$, diâmetro médio de partícula de $40 \mathrm{~nm}$ e porcentagem de $\mathrm{SiO}_{2}$ superior a 99,8\% [DEGUSSA S/A, 1993]. A figura I.3.1.3.1 mostra a mictoscopia de transmissão eletrônica (TEM). Esté tipo de slíca possui uma baixa superfície específica e ligeira tendência a aglomerar. 


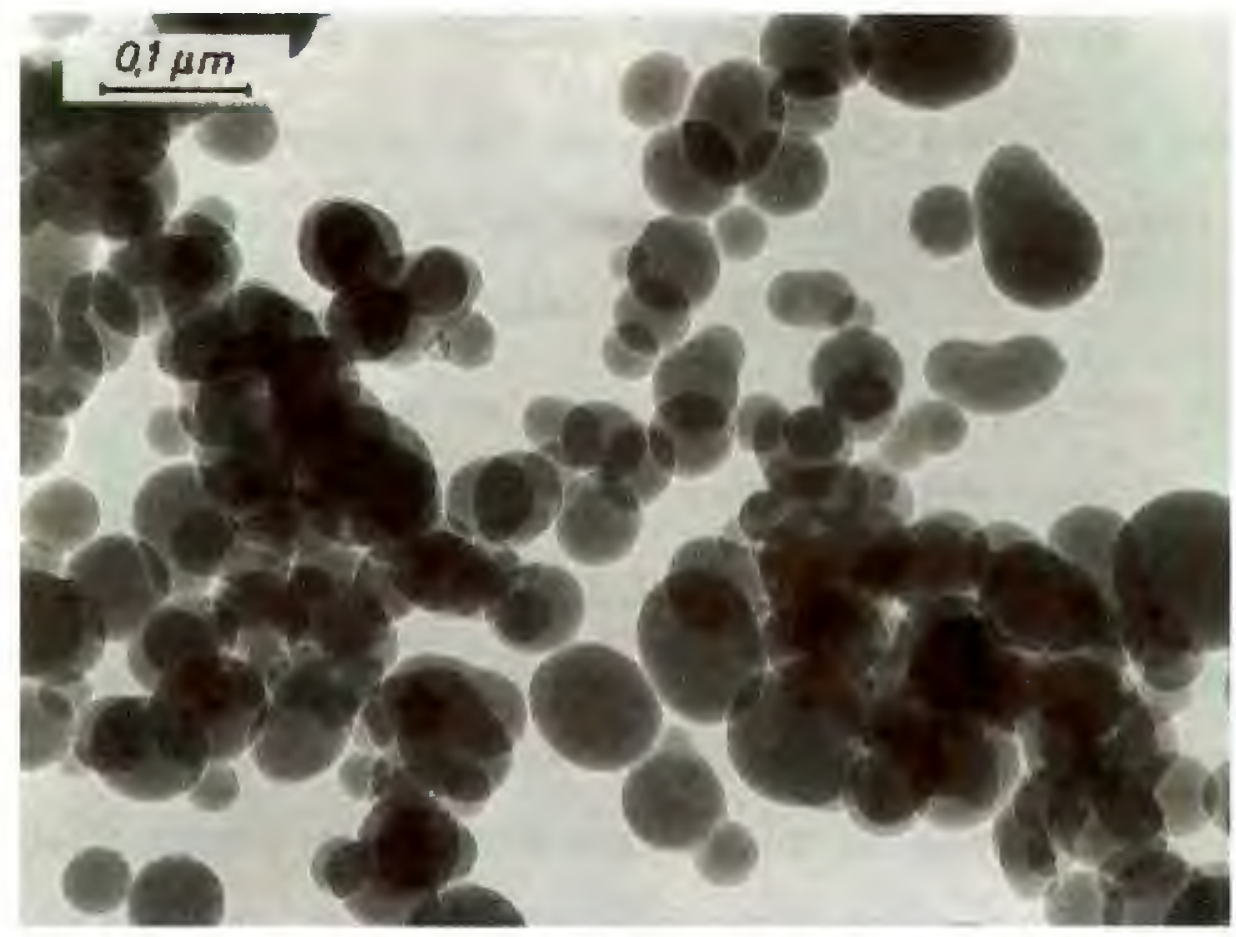

Figura I.3.1.3.1 - TEM de AEROSIL OX-50.

Micrografia eletrônica de varredura (SEM) de seção transversal congelada de uma dispersão de AEROSIL OX-50 em 1,2-etanodiol mostra que o diâmetro da partícula se apresenta efetivamente em uma faixa extensa. Isso também é confirmado por análise de sedimentação, como mostrado na figura I.3.1.3.2.

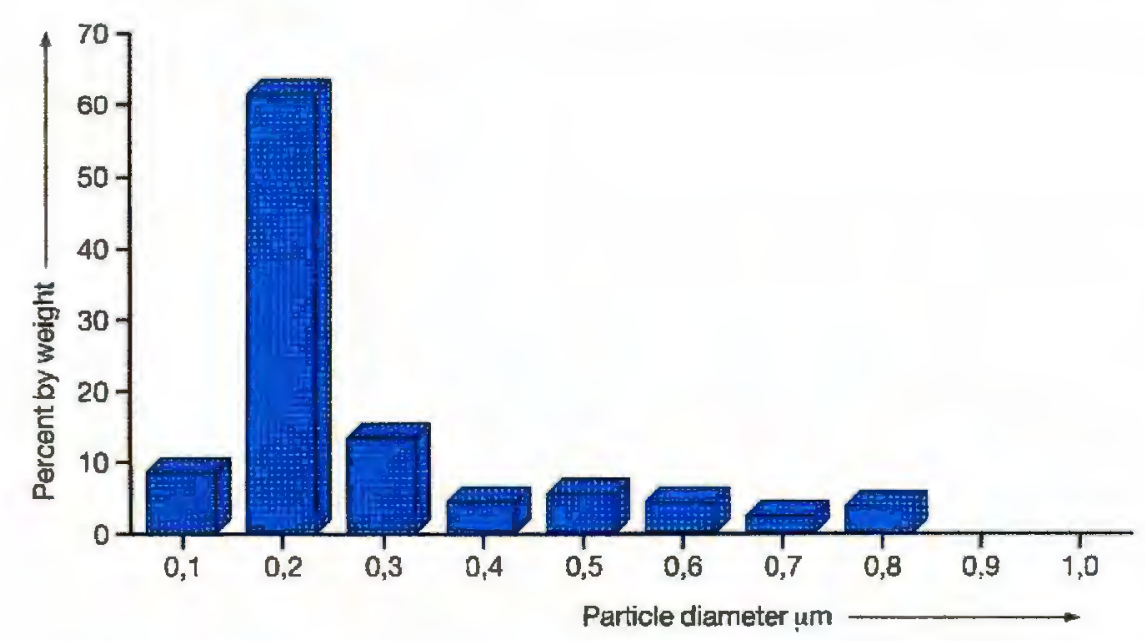

Figura I.3.1.3.2 - Distribuição de tamanho de partícula em dispersão $20 \%$ de AEROSIL OX-50 em 1,2 etanodiol, análise de sedimentação por centrifugação. 


\section{I.3.2-Superfícies planares de $\mathrm{SiO}_{2}$ obtidas por oxidação térmica}

Todo o desenvolvimento de microeletrônica está baseado na química do silício, e no fato do silício poder ser obtido na forma de lâminas planares a partir de processos especiais de fabricação [Enderlein, 1995].

O óxido de silício pode ser obtido essencialmente por dois processos: oxidação térmica e por métodos de deposição química por fase vapor.

$\mathrm{Na}$ oxidação térmica do silício coloca-se a lâmina num forno onde o ambiente é oxidante, de modo que ocorra uma reação entre o elemento oxidante e o silício para a formação do óxido, no entanto não é necessário um processo radical como a oxidação térmica em altas temperaturas para que uma camada de óxido de silício se forme espontaneamente sobre o silício em presença de oxigênio.

As reações abaixo descrevem o processo de oxidação térmica de silício em oxigênio e em vapor de água, respectivamente.

$$
\begin{aligned}
& \mathrm{Si} \text { (sólido) }+\mathrm{O}_{2} \longrightarrow \mathrm{SiO}_{2} \text { (sólido) } \\
& \mathrm{Si} \text { (sólido) }+\mathrm{H}_{2} \mathrm{O} \longrightarrow \mathrm{SiO}_{2} \text { (sólido) }+2 \mathrm{H}_{2} \text { (gás) }
\end{aligned}
$$

As temperaturas do processo de oxidação estão na faixa de 800 a $1200^{\circ} \mathrm{C}$.

Além de oxigênio e vapor de água, também se pode usar outros produtos químicos que não só aumentam a velocidade do processo de oxidação, mas também melhoram as qualidades elétricas do óxido produzido. As substâncias mais usadas são o tricloroetileno $\left(\mathrm{C}_{2} \mathrm{H}_{3} \mathrm{Cl}_{3}\right)\left(+\mathrm{O}_{2}\right)$ e o ácido clorídrico $(\mathrm{HCl})\left(+\mathrm{O}_{2}\right)$.

A oxidação térmica convencional utiliza-se de grandes fornos de oxidação, sendo que o processo de oxidação leva um tempo consideravelmente longo, dependendo da espessura do óxido desejado. Tipicamente serve para produzir óxidos espessos, onde a pressão do oxigênio, a orientação do substrato, e a temperatura de oxidação são os parâmetros que ditam o processo de oxidação.

Quando se deseja a produção de camadas finas ou ultrafinas de óxidos temse utilizado a oxidação térmica rápida, que se caracteriza principalmente pelo baixo 
tempo necessário para que a oxidação ocorra, geralmente alguns minutos. Para essas camadas finas o principal parâmetro a ser considerado no processo de oxidação passa a ser a estado químico e físico da superfície, pois a mesma passa a ocupar uma grande fração da totalidade do material. Particularmente, os processos de limpeza passam a ser o passo determinante na obtenção de óxidos de alta qualidade [dos Santos Filho et al., 1995; dos Santos Filho e Hasenack, 1995].

O óxido de silício obtido por oxidação térmica (convencional ou rápida) caracteriza-se por se bem homogêneo, possuindo um baixo número de grupos silanol (Si-OH) na superfície.

Os óxidos de silício obtidos por diferentes processos microeletrônicos são amorfos [Adams, A. C. e Katz, L. E., 1985], e como conseqüência apresentam as características superficiais dos óxidos amorfos expostos acima, ou tornam-se hidrofóbicos ao serem tratados termicamente acima de certas temperaturas. Particularmente, o óxido de silício obtido por deposição química por fase vapor pode ser obtido com uma superfície mais hidrofilica que a do óxido térmico, dependendo das condições de processo e do reagente utilizado.

\section{I.3.2.1 - Caracterização de superficies}

\section{I.3.2.1.1 - Ângulo de contato}

Uma interface é, como o nome sugere, uma fronteira entre fases. Pelo fato das interfaces serem muito finas, na maioria dos casos apenas alguns diâmetros moleculares de espessura, nós algumas vezes tendemos a imaginá-las como bidimensionais, e negligenciamos a sua espessura. No entanto, a terceira dimensão é de grande significado. De fato, as mudanças rápidas na densidade e/ou composição através das interfaces fornece a elas sua propriedade mais importante, um excesso de energia livre ou tensão lateral que é usualmente denominada tensão interfacial. 
Quando três fases estão presentes, três interfases são possíveis, uma para cada par de fluidos. Algumas vezes todas as três interfaces se encontram, e a junção delas forma uma curva conhecida como a linha de contato de três fases. Se uma das fases é um sólido, a linha de contato situa-se ao longo da superfície. Neste caso o ângulo que a interface fluida faz com a superfície sólida é chamado ângulo de contato. Como ele determina as propriedades de molhabilidade dos sólidos pelos líquidos, o ângulo de contato é uma segunda propriedade fundamental importante nos fenômenos interfaciais [Clarence e Neogi, 1985].

Tensão interfacial (superficial) e ângulo de contato são suas grandezas diferentes, embora elas estejam estreitamente relacionadas. Tensão superficial descreve a coesão de moléculas na interface entre duas fases. Duas fases devem ser especificadas para descrever a tensão superficial; três fases são necessárias para descrever ângulo de contato.

Tensão superficial $(\gamma)$ é uma força que opera sobre uma superfície e age perpendicularmente e para o interior das fronteiras da superfície, tendendo a diminuir a área da interface.

De fato, num líquido esta definição é apropriada, pois no mesmo as moléculas situadas no seu interior são em média, sujeitas a forças de atração iguais em todas as direções, ao passo que as moléculas situadas, por exemplo, numa interface líquido/ar estão submetidas a forças de atrações não balanceadas ou não equilibradas, o que resulta uma força em direção ao interior do líquido. $O$ maior número possível de moléculas se deslocará da superfície para o interior do líquido e a superfície tenderá a contrair-se espontaneamente. Isso explica porque gotículas de um líquido ou bolhas de ar tendem a adquirir forma esférica [Shaw, 1975].

Os vários efeitos de superfície podem ser expressos em relação à variação de energia livre de Gibbs $(\Delta G)$ sob o aspecto termodinâmico [Hiemenz, 1986]. 
Considerando-se o trabalho infinitesimal dW necessário para aumentar a área de uma certa superfície $d \sigma$, tem-se que infinitesimalmente ocorre a seguinte relação:

$$
d W=\gamma \cdot d \sigma
$$

no entanto, à temperatura $(\mathrm{T})$ e pressão $(\mathrm{P})$ constantes, tem-se $d W=d G, \operatorname{logo}$,

$$
d G=\gamma \cdot d \sigma
$$

onde $\gamma$ é a tensão superficial.

Assim pode-se definir tensão superficial e energia livte superficial como o trabalho necessário para aumentar a superfície em uma unidade de área, por um processo isotérmico e reversivel.

Um último aspecto a ser considerado reside no fato da tensão superficial variar com a temperatura, onde com o aumento da temperatura há uma diminuição da tensão superficial (exceção feita para alguns metais), sendo que esta relação é quase linear.

Deste modo, em experimentos envolvendo tensão superficial é necessário o uso de temperatura constante.

Pode-se medir a tensão superficial de várias maneiras.

Os métodos para a medida de tensão superficial, ou tensão interfacial, podem ser divididos em [Rabockai, 1979]:

(1) Estáticos: por exemplo, os métodos de ascensão capilar e da gota pendente.

(2) Dinâmicos: sendo que os métodos dinâmicos podem ser divididos em dois grupos:

(2.1) Métodos nos quais a superfície é rompida durante o processo de medida. Por exemplo, o método do anel, e o método da placa de Wilhelmy. 
(2.2) Métodos nos quais a superfície se encontra em movimento durante a medida. São exemplos os métodos de escoamento e das ondas capilares.

Quando uma gota de um líquido é colocada sobre uma superfície sólida plana ela poderá espalhar-se como um filme mais ou menos uniforme, ou permanecerá como uma gota, com um ângulo de contato com a superfície sólida [Good, 1993; Padday, 1993].

Medidas de ângulo de contato são usuais como um meio de caracterizar os estados físicos e químicos de superfícies complexas [Israelachvili e Gee, 1989].

A medida de ângulo de contato entre uma gota e uma superfície sólida pode esclarecer muitos processos importantes tais como molhabilidade, adsorção e adesão, e características da superfície incluindo heterogeneidades químicas, limpeza e orientação molecular [Hiemenz, 1986]. Ângulos de contato elevados entre uma superfície sólida e um líquido (água) indicam que a superfície é hidrofóbica, pois a superfície é pouco molhada pelo líquido. Podemos perceber se houve mudanças de hidrofilicidade/hidrofobicidade em uma superfície, causadas pela adsorção de algum adsorbato, através da alteração nos valores de ângulo de contato entre esta superfície e uma gota de água. A histerese do ângulo de contato (diferença entre os ângulos de contato de avanço e recesso) nós fornece indicação sobre a homogeneidade química ou topográfica da superfície. Por exemplo, para superfícies de poliestireno sem carga, ângulo de contato de avanço e recesso diminuem em função da concentração de anfifilico utilizado. Os valores de ângulo de contato também mostram uma dependência com a hidratação do contraíon do anfifilico catiônico, mostrando o efeito molecular sobre a molhabilidade [Lessa e CarmonaRibeiro, 1996].

$\mathrm{O}$ ângulo de contato é definido como o ângulo (medido no líquido), formado na junção de três fases, por exemplo, junção sólido/líquido/gás. 
$\mathrm{O}$ ângulo de contato pode ser determinado matematicamente a partir de tensões superficiais que podem ser encaradas como forças ao longo do perímetro de uma gota (figura I.3.2.1.1.1), através da equação de Young [Hiemenz, 1986].

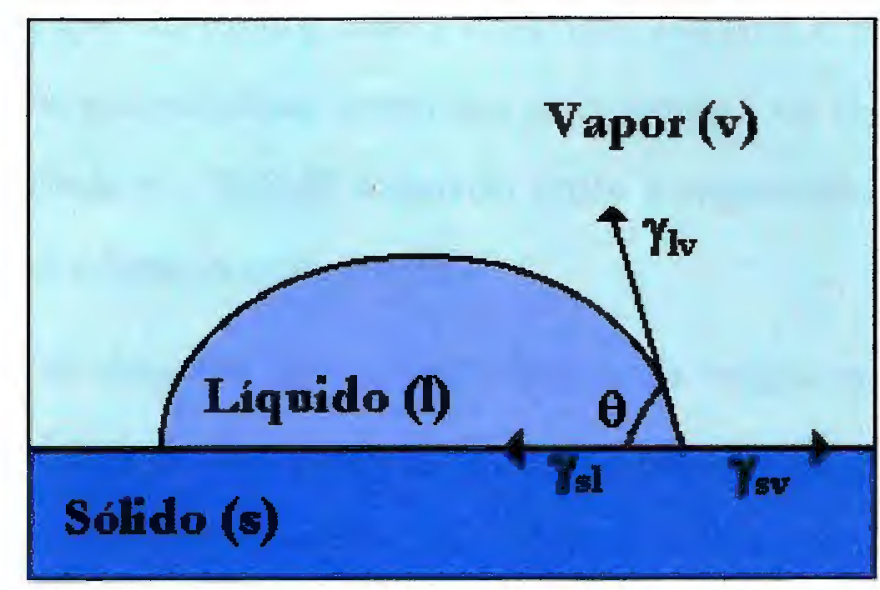

Figura I.3.2.1.1.1 - Componentes da tensão interfacial necessários para a dedução da equação de Young.

$$
\gamma_{s / v}=\gamma_{s / l}+\gamma_{l / v} \cos \theta \quad \text { (Eq. de Young) Eq. I.3.2.2.1.3 }
$$

onde,

$\gamma_{s / v}$ é a tensão superficial na interfase sólido/gás;

$\gamma_{s / l}$ é a tensão superficial na interfase sólido/líquido;

$\gamma_{l / v}$ é a tensão superficial na interfase líquido/gás;

$\theta$ é o ângulo de contato entre a gota e o sólido.

O sólido se mostrará completamente umedecido pelo líquido se o ângulo de contato for zero, e somente parcialmente umedecido se o ângulo de contato tiver um valor finito.

A media de ângulo de contato para gotas crescentes dá origem ao ângulo de contato de avanço, $\theta_{A}$, e a medida de ângulo de contato de gotas de tamanhos decrescentes dá origem ao ângulo de contato de recesso, $\theta_{R}$. 
Os ângulos de contato são estáticos ou dinâmicos dependendo de se a fronteira líquido/sólido/gás é estacionária ou móvel durante a medição.

Para medidas de ângulos de contato estáticos o método mais utilizado é o da gota séssil ou gota pendente, onde uma gota é coloca sobre uma determinada superfície e o ângulo que ela forma com a superfície durante o avanço ou recesso é medido através de um microscópio como um goniômetro, ou tem sua projeção em um anteparo fotografada e o ângulo formado entre a superfície e a gota é medido. Este tipo de medida é relativamente simples.

Para medidas de ângulos de contato dinâmicos utiliza-se um aparelho para medidas de forças do tipo Dynometer, em um método da placa de Wilhelmy modificado [Johnson et al. 1977], onde uma lâmina sólida acoplada ao aparelho é imersa (avanço) e retirada (recesso) de uma determinada solução contida em um recipiente, de modo que o ângulo obtido é de maneira indireta a partir das forças que atuam sobre a lâmina, em função do tempo de imersão ou de retirada da lâmina na solução, e conhecendo-se o perímetro da lâmina, a tensão superficial da solução em estudo, e a aceleração da gravidade local. A figura I.3.2.1.1.2 mostra um esquema das forças que atuam sobre a lâmina durante a medida de ângulo de contato dinâmico. 


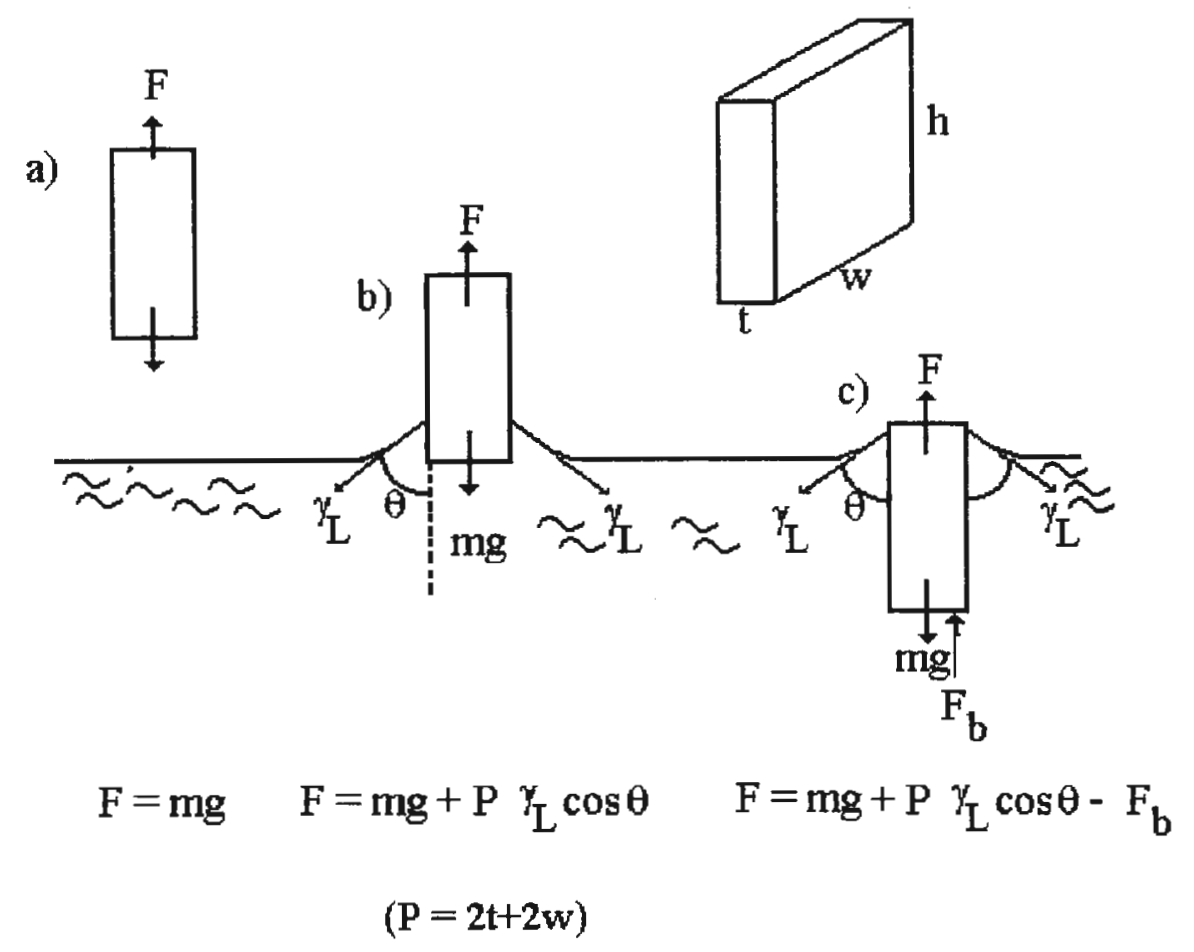

F: força resultante

m: massa da superfície

g: aceleração da gravidade

P: perímetro da placa

$\gamma_{\mathrm{L}}:$ tensão superficial do líquido

$\theta$ : ângulo de contato

$\mathrm{F}_{\mathrm{b}}$ : empuxo

Figura I.3.2.1.1.2 - Princípio da medida de ângulo de contato dinâmico pelo método modificado de Wilhelmy.

Um aspecto muito importante a ser considerado é o fệômeno da histerese, definida como sendo a diferença entre o ângulo de contato de avanço $\left(\theta_{A}\right)$ e o de recesso $\left(\theta_{R}\right)[$ Hiemenz, 1986].

O equilíbrio termodinâmico de um líquido numa superfície sólida ideal é caracterizado por um único ângulo de contato. Entretanto, já é um fato bem conhecido que um amplo conjunto de ângulos de contato estáveis aparentes podem ser medidos em superfícies reais, que são usualmente rugosas e/ou heterogêneas. Heterogeneidade química contribui para este fenômeno simplesmente devido a variações espaciais na energia de superfície do sólido. O efeito da rugosidade é devido à mudança do ângulo de contato aparente, mesmo se o ângulo de contato 
intrínseco é uniforme sobre toda a superfície sólida, devido a mudanças locais na inclinação desta superfície [Marmur, 1996].

Foi demostrado que a histerese do ângulo de contato é teoricamente similar a outros tipos de histerese existentes na natureza. O conceito unificador é que a histerese requer um grande número de estados metaestáveis que são acessíveis ao sistema. Estados metaestáveis que causam a histerese do ângulo de contato podem ser criados pela rugosidade da superfície ou pela heterogeneidade da superfície [Johnson et al., 1977].

Por fim tem-se que a medida de ângulo de contato, seja ele dinâmico ou estático, constitui uma técnica versátil para caracterização de modificações em superfícies sólidas dos mais diferentes tipos.

\section{I.3.2.1.2-Elipsometria}

Elipsometria é uma técnica óptica utilizada na caracterização e observação de eventos em uma interface ou filme entre dois meios e é baseado na exploração da transformação de polarização que ocorre à medida que um feixe de luz polarizada é refletido a partir de, ou transmitida através de uma interface ou filme. Dois fatores fazem da elipsometria particularmente atrativa: (1) seu caráter essencialmente não perturbador (quando o comprimento de onda e intensidade do feixe de luz são corretamente escolhidos), conseqüentemente sua conveniência para medidas in-situ, e (2) sua notável sensibilidade para efeitos interfaciais minúsculos, como a formação de uma submonocamada de átomos ou moléculas distribuída de forma esparsa [Azzam e Bashara, 1987].

A grande diversidade de situações na natureza e sistemas artificiais onde interfaces e filmes têm um papel importante tem levado a aplicação da elipsometria em diversas áreas, como a física, química, ciência de materiais e fotografia, biologia, assim como, óptica, eletrônica, mecânica, metalurgia e engenharia biomédica [Azzam e Bashara, 1987]. 
A adsorção de espécies moleculares ou atômicas sobre superfícies em contato com ambiente líquido tem sido estudada de forma não destrutiva e in situ por elipsometria. Elipsometria pode detectar tanto adsorção física quanto quimiosorção. $O$ termo adsorção implica reversibilidade; uma camada adsorvida pode ser desorvida, por exemplo, por aquecimento. Isso está em contraste com a formação de filmes permanentes, como os óxidos.

Um caso de considerável importância em elipsometria é aquele em que a luz polarizada é refletida a partir e/ou transmitida por um substrato recoberto por um filme simples. Como mostra a figura I.3.2.1.2.1, é assumido que o filme tem as bordas paralelas ao plano de separação (espessura de filme) $d_{1}$, e está entre os ambiente semi-infinito (imersão) e o substrato. $\mathrm{O}$ ambiente (meio 0), o filme (meio 1) e o substrato (meio 2) são homogêneos e opticamente isotrópicos, com índices de refração complexos $N_{0}, N_{1}$ e $N_{2}$, respectivamente. Na maioria dos casos, o meio de incidência é transparente e $\mathrm{N}_{0}$ é real.

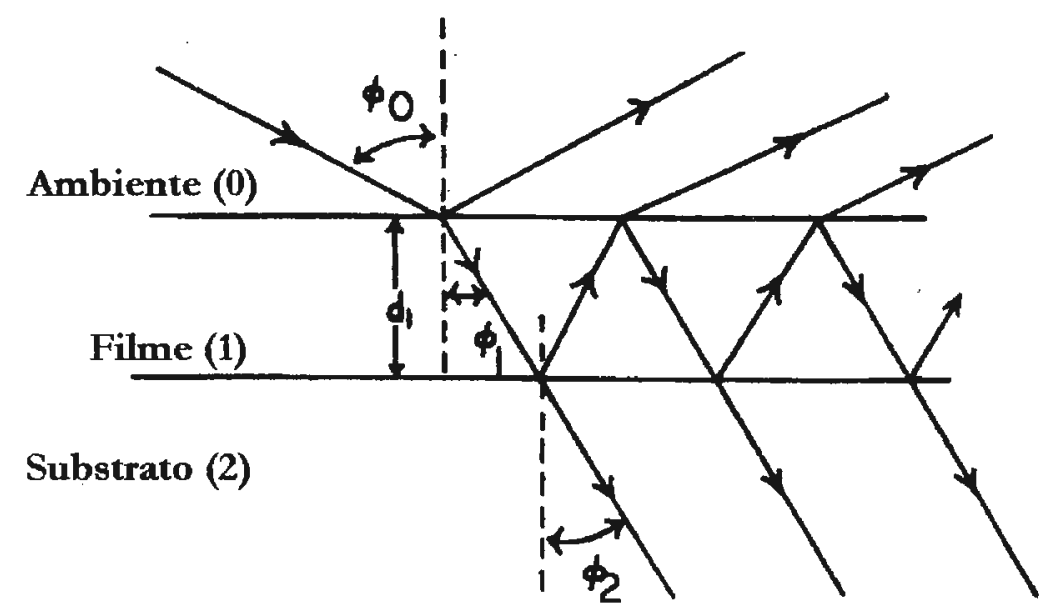

Figura I.3.2.1.2.1 - Reflexão e transmissão obliqua da onda plana por um sistema ambiente (0)-filme (1)-substrato (2) com fronteiras paralelas ao plano. $d_{1}$ é a espessura do filme. $\phi_{0}$ é o ângulo de incidência no ambiente e $\phi_{1}, \phi_{2}$ são os ângulos de refração no filme e no substrato, respectivamente. 
O procedimento seguinte é baseado no quadro físico da figura I.3.2.1.2.3. Especificamente, é assumido que quando a onda incidente encontra a interface $0 / 1$, parte será refletida no meio 0 e parte será refratada no filme, de acordo com o coeficiente de reflexão e transmissão de Fresnel da interface. A onda refratada dentro do filme subseqüentemente sofre reflexões internas múltiplas nas fronteiras do filme nas interfaces $1 / 2$ e $1 / 0$ que, em geral, não são perfeitamente refletoras. Assim, cada vez que a onda multi-refletida no filme colide com as interfaces $1 / 0$ ou $1 / 2$, uma componente (parcial) da onda "vaza" (refrata) no ambiente semi-infinito ou no substrato, respectivamente. Se os coeficientes de reflexão e transmissão de Fresnel nas interfaces $0 / 1$ e $1 / 2$ são indicados por $r_{01}, t_{01}\left(r_{10}, t_{10}\right)$ e $r_{12}, t_{12}$, respectivamente, as amplitudes complexas das ondas planas parciais sucessivas que constituem a onda refletida resultante no meio 0 são dadas por $r_{01}, t_{01} t_{10} r_{12} e^{-22 \beta}$, $t_{01} t_{10} r_{10} r_{12}^{2} e^{-i 4 \beta}, t_{01} t_{10} r_{10}^{2} r_{12}^{3} e^{-i 6 \beta}, \ldots$, enquanto as amplitudes complexas das ondas planas parciais sucessivas que constituem a onda transmitida no meio 2 são dadas por $t_{01} t_{12} e^{-i \beta}, t_{01} t_{12} r_{10} r_{12} e^{-i 3 \beta}, t_{01} t_{12} r_{10}^{2} r_{12}^{2} e^{-i 5 \beta}, \ldots$, onde $\beta$ é a mudança de fase que a onda multi-refletida dentro do filme sofre ao atravessar o filme uma vez de uma fronteira para outra. Em termos de comprimento de onda no espaço livre $\lambda$, a espessura do filme $d_{1}$, o índice de refração complexo $N_{1}$ e o ângulo de refração no filme $\phi_{1}$ (o ângulo entre a direção de propagação da onda zig-zag no filme e a normal às fronteiras do filme), a fase do ângulo, $\beta$, é dada por:

$$
\beta=2 \pi\left(\frac{d_{1}}{\lambda}\right) N_{1} \cos \phi_{1}
$$

Se a lei de Snell é aplicada, onde $\phi_{0}$ é o ângulo de incidência (no meio 0).

$\mathrm{Na}$ dedução acima, a onda incidente é assumida como sendo de amplitude unitária e com componentes de polarização paralela $(p)$ ou perpendicular $(s)$ ao plano de incidência. 
A adição das ondas parciais pode ser representada por uma série geométrica infinita para a amplitude refletida total $R$ :

$$
R=r_{01}+t_{01} t_{10} r_{12} e^{-i 2 \beta}+t_{01} t_{10} r_{10} r_{12}^{2} e^{-i 4 \beta}+t_{01} t_{10} r_{10}^{2} r_{12}^{3} e^{-i 6 \beta}+\ldots \quad \text { Eq. I.3.2.1.2.2 }
$$

cuja soma dá:

$$
R=\frac{r_{01}+r_{12} e^{-i 2 \beta}}{1+r_{01} r_{12} e^{-i 2 \beta}}
$$

se a substituição $r_{10}=-r_{01}$ e $t_{01} t_{10}=1-r_{01}^{2}$ é feita. Similarmente para a amplitude total transmitida, $T$ é dada por uma série geométrica infinita.

$$
\begin{array}{cc}
T=t_{01} t_{12} e^{-i \beta}+t_{01} t_{12} r_{10} r_{12} e^{-i 3 \beta}+t_{01} t_{12} r_{10}^{2} r_{12}^{2} e^{-i 5 \beta}+\ldots & \text { Eq. I.3.2.1.2.4 } \\
T=\frac{t_{01} t_{12} e^{-i \beta}}{1+r_{01} r_{12} e^{-i 2 \beta}} & \text { Eq. I.3.2.1.2.5 }
\end{array}
$$

Essas equações são válidas quando a onda incidente é linearmente polarizada tanto paralela $(p)$ ou perpendicular $(s)$ ao plano de incidência. Assim, podem ser escritas as equações para $R$ e $T$ adicionando-se a polarização, como segue:

$$
\begin{aligned}
& R_{p}=\frac{r_{01 p}+r_{12 p} e^{-i 2 \beta}}{1+r_{01 p} r_{12 p} e^{-i 2 \beta}} \\
& R_{s}=\frac{r_{01 s}+r_{12 s} e^{-i 2 \beta}}{1+r_{01 s} r_{12 s} e^{-i 2 \beta}} \\
& T_{p}=\frac{t_{01 p} t_{12 p} e^{-i \beta}}{1+r_{01 p} r_{12 p} e^{-i 2 \beta}} \\
& T_{s}=\frac{t_{01 s} t_{12 s} e^{-i \beta}}{1+r_{01 s} r_{12 s} e^{-i 2 \beta}}
\end{aligned}
$$

onde $\beta$ é o mesmo para polarizações $p$ e $s$. 
A medida dos parâmetros elipsométricos $\Psi$ e $\Delta$, estão relacionados à $R_{p} \mathrm{e}$ $R_{s}$ por:

$$
\frac{R_{p}}{R_{s}}=\tan \Psi e^{i \Delta}
$$

onde:

$\Delta=\delta_{1}-\delta_{2}$, sendo $\delta_{1}=$ diferença de fase entre as componentes paralela $\mathrm{e}$ perpendicular da radiação incidente e $\delta_{2}=$ diferença de fase entre as componentes paralela e perpendicular da radiação refletida e, $\tan \Psi=\frac{\left|R_{p}\right|}{\left|R_{s}\right|}$, relação entre as amplitudes paralelas e perpendicular.

$\Psi$ e $\Delta$ são os ângulos medidos experimentalmente na elipsometria.

Técnicas de elipsometria têm sido utilizadas para caracterização de adsorção de vários adsorbatos sobre superfícies de sillica. Dentre esses adsorbatos podemos citar proteínas [Jönsson et al, 1985; Malmsten, 1994; Malmsten et al, 1995], surfactantes [Tiberg e Landgren, 1993; Wängnerud e Jönsson, 1994a; Wängnerud e Jönsson, 1994b; Tiberg et al, 1994a e b; Harwigsson et al, 1996; Luciani e Denoyel, 1997; Strom et al, 1999; Brinck et al, 1999], polímeros [Tran et al, 1999; Wagberg e Nygren, 1999; Stemme e Odberg, 1999].

\section{I.4 - Forças de interação}

\section{Força atrativa de van der Waals}

Entre duas superfícies planares a energia de interação de van der Waals é dada por:

$$
W(D)=-\frac{A}{12 \pi D^{2}} \quad \text { por unidade de área da superfície } \quad \text { Eq. I.4.1 }
$$


onde $A$ é a constante de Hamaker não retardada. As forças de van der Waals entre estruturas anfifilicas são geralmente pequenas por três razões. Primeiro, entre as fases hidrocarbônicas através da água, $A$ é relativamente pequena, permanecendo entre $4-7 \times 10^{-21} \mathrm{~J}$. Para membranas biológicas deve ser esperado valor mais alto devido à presença de proteínas cujo índice de refração é geralmente maior que das cadeias hidrocarbônicas fluidas: 1,55-1,60 comparado a 1,42-1,48.

Segundo, a equação I.4.1, quando aplicada a bicamada ou membranas, é somente válida a distancias de separação $D$ abaixo de $3 \mathrm{~nm}$. Acima de $3 \mathrm{~nm}$ a constante de Hamaker não é grande, mas diminui progressivamente com o aumento de $D$ devido a efeitos de retardação e a espessura finita da bicamada, e para $10 \mathrm{~nm}$ a força é usualmente muito menor que a metade do valor dado pela equação não retardada.

Terceiro, na presença de eletrólito há uma redução adicional de $A$ a separações finitas devido à blindagem iônica de contribuição de freqüência zero $A_{v=0}$, que é dado por:

$$
A_{v=0}(D)=A_{\nu=0}(0) 2 \kappa D e^{-2 \kappa D}, \quad \text { para } k D>>1, \quad \text { Eq. I.4.2 }
$$

onde $\kappa$ é o comprimento de Debye e onde para hidrocarbonetos através de água $A_{v=0}(0)=3 \times 10^{-21} \mathrm{~J}$. A equação I.4.2 é válida dentro de $15 \%$ para $\kappa D>2$. Assim, em solução $0,15 \mathrm{M}$ de $\mathrm{NaCl}$, onde $\kappa^{-1}=0,8 \mathrm{~nm}$, o termo de freqüência zero, que leva vale cerca da metade da força não retardada, praticamente desaparece para $D=1,5 \mathrm{~nm}$.

A força de van der Waals entre bicamadas e membranas, especialmente em altas concentrações salinas, é fraca e tem um alcance efetivo de $15 \mathrm{~nm}$, além de que é tão fraca para ser de maior importância. 


\section{Forcas eletrostáticas (dupla camada)}

A repulsão da dupla camada, ao contrário da atração de van der Waals, é muito mais sensível ao tipo e concentração de eletrólitos presentes, o $\mathrm{pH}$ e a densidade superficial de carga e potencial. Uma expressão aproximada para energia de interação de dupla camada entre duas superfícies é dada pela equação I.4.3.

$$
W=\left(\frac{64 k T \rho_{\infty} \gamma^{2}}{\kappa}\right) e^{-\kappa D}
$$

Onde $\rho$ é a concentração iônica e $\gamma=\tanh \left(\frac{z e \psi_{0}}{4 k T}\right)$

A interaçăo entre as forças atrativas de van der Waals e repulsiva de dupla camada forma a base da teoria de DLVO. Ambas as forças tem sido medidas diretamente entre surfactantes aniônicos ou catiônicos e bicamadas lipídicas em soluções aquosas de eletrólitos mono e bivalentes [Israelachvili, 1992].

Em altas concentrações de eletrólito monovalente a repulsão geralmente diminui, mas devido à atração de van der Waals, relativamente fraca, entre bicamadas lipídicas, a repulsão permanece forte suficiente para deixar as superfícies separadas, mesmo para potenciais de superfícies baixos e em altas concentrações salinas. Isso é ilustrado na figura 4.1 para duas bicamadas em solução salina fisiológica $(\sim 0,15 \mathrm{M} \mathrm{NaCl})$ onde um mínimo secundário fraco aparece a $4-6 \mathrm{~nm}$ para valores típicos de $\psi_{0}$ e $A$. 


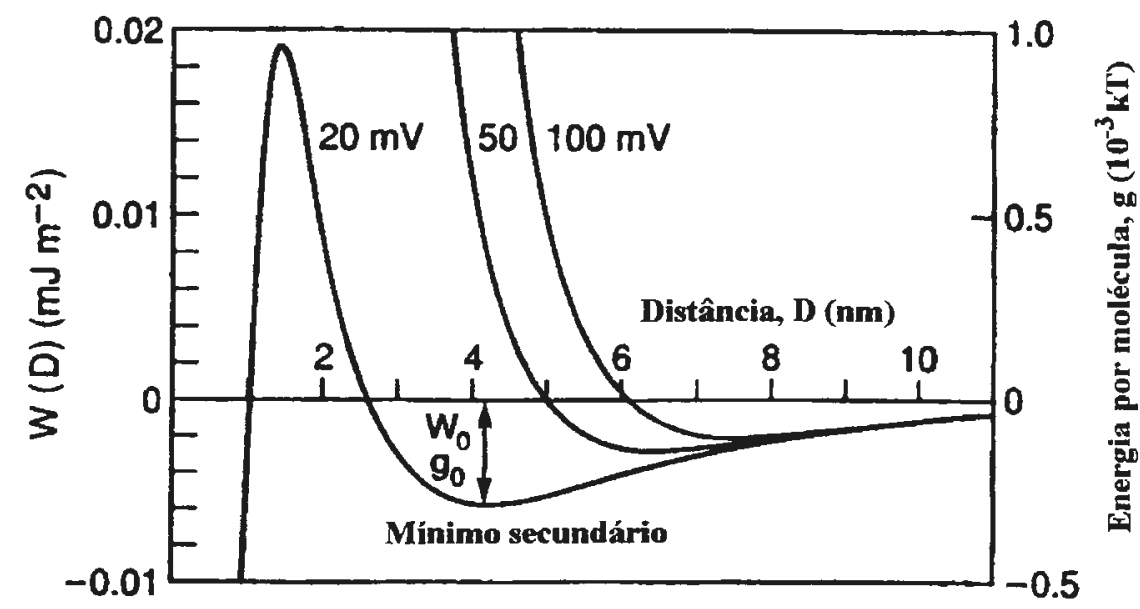

Figura 4.1 - Energia de interação teórica de DLVO por unidade de área entre duas superfícies de anfifilicos em $0,15 \mathrm{M} \mathrm{NaCl}$. A constante de Hamaker não retardada é assumida como sendo $A=6 \times 10^{-21} \mathrm{~J}$ e as superfícies são assumidas para atrair a um potencial de superfície constante $\psi_{0}$. As três curvas a $\psi_{0}=100,50$ e $20 \mathrm{mV}$ corresponde a densidades superficiais de carga de 1 e por 1,3 e $8,5 \mathrm{~nm}^{2}$, respectivamente. A energia por molécula $g=\frac{1}{2} W a_{0}$ é calculada para uma área por cabeça polar de $a_{0}=0,4 \mathrm{~nm}^{2}$. Note que no interior do mínimo secundário a energia de adesão de $W_{0} \approx 6 \times 10^{-3} \mathrm{mJm}^{-2}$ corresponde a uma energia de cerca de $3 \times 10^{-4} \mathrm{kT}$ por molécula.

A situação na prática é freqüentemente muito mais complexa. Abaixo de $3 \mathrm{~nm}$ forças repulsivas de hidratação e estérica podem dominar a interação dependendo da hidrofobicidade e mobilidade térmica dos grupos superficiais. Por outro lado, forças atrativas de correlação iônica e hidrofóbica podem dominar dependendo do stress sobre a bicamada e da presença de íons bivalentes.

\section{Forcas de bidratacão}

Forças de hidratação repulsiva aparece sempre que moléculas de água se ligam fortemente a grupos hidrofilicos da superfície porque da energia necessária para desidratar esses grupos como duas superfícies próximas. Entre duas superfícies cristalinas sólidas a força de hidratação é usualmente oscilatória. As oscilações têm uma periodicidade do diâmetro da molécula de água, cerca de $0,25 \mathrm{~nm}$, e reflete a ordenação das moléculas de água nas camadas semidiscreta 
entre as superfícies lisas e rígidas. Entre superfícies de bicamadas não tão ordenadas entre camadas bem definidas é possível porque (1) as cabeças são rugosas para a escala de uma molécula de água, e (2) as superfícies são usualmente termicamente móveis fazendo aparecer uma repulsão estérica [Caffrey e Bilderback, 1983].

O alcance das forças de hidratação e estérica medidas entre vários surfactantes e bicamadas é cerca de $1-3 \mathrm{~nm}$, abaixo eles crescem exponencialmente, com comprimentos de decaimento alcançando de 0,08 a 0,64 $\mathrm{nm}$. Forças de hidratação e estérica freqüentemente domina das forças de DLVO em separações pequenas, prevenindo a coalescência no mínimo primário das bicamadas, vesículas e membranas biológicas. Em partículas, essas forças são responsáveis pela falta de forte adesão ou agregação de bicamadas e vesículas compostas de lipídios não carregados como lecitinas.

Infelizmente, por causa do curto alcance dessas forças entre superfícies anfifílicas, não é possível separar a contribuição crescente do efeito da força de hidratação (solvatação) e da força de flutuação térmica (estérica).

\section{Forcas estéricas}

Com a aparente falha dos modelos baseados puramente em interações eletrostáticas e de solvatação para explicar as interações entre superfícies de anfifilicos, tem sido focalizado o papel das interações de flutuação térmica.

Quatro diferentes tipos de forças estéricas repulsivas podem aparecer entre bicamadas interagindo em qualquer líquido, isto é, independente do solvente. Há a força de ondulação, força peristáltica, força de protusão e a força de sobreposição estérica entre superfície ancorada e cabeças polares. Abaixo estão sumarizadas as equações aproximadas para cada uma dessas forças (por unidade de área). 
Ondução

$$
F \approx \frac{(k T)^{2}}{2 k_{b} D^{3}}
$$

Peristáltica

$$
F \approx \frac{(k T)^{2}}{5 k_{a} D^{5}}
$$

Protusão

$$
F \approx \frac{2,7 \Gamma k T e^{-D . \lambda}}{\lambda}, \quad \text { onde } \lambda \approx \frac{k T}{\alpha_{p}}, \quad \text { Eq. I.4.6 }
$$

Sobreposição de cabeças polares

$$
F \approx 100 \Gamma^{3 / 2} k T e^{-D i \lambda}, \quad \text { onde } \lambda \approx L / \pi \quad \text { Eq. I.4.7 }
$$

onde, na última interação, $L$ é a espessura efetiva da região polar flutuante e $2 L$ é o alcance da interação.

Das quatro forças estéricas listadas acima, somente a força de ondulação é esperada a ter um alcance indefinidamente longo; as outras três forças decaem rapidamente a zero além de uma certa distância aproximadamente igual ao comprimento das moléculas de lipídio.

\section{Forcias de interacão bidrofóbica}

A interação hidrofóbica atrativa entre moléculas de hidrocarbonetos ou superfície em água é de surpreendente longo alcance e muito mais forte que a atração de van der Waals para pequenas distâncias de separação. No caso de bicamadas livres, as cabeças hidrofilicas blindam os grupos hidrocarbônicos na fase aquosa, que efetivamente mascara a interação hidrofóbica entre eles. No entanto, quando bicamadas são sujeitas a uma força de estiramento, elas expandem lateralmente, e a área hidrofóbica aumentada exposta para a fase aquosa permite o surgimento da interação hidrofóbica. 


\section{I.4.1 - Interações entre bicamadas e superficies}

Os fatores físicos e químicos que determinam a deposição de vesículas de fosfolipídios ou de anfifilicos sintéticos em superfícies sólidas ainda não foram estudados em profundidade, excetuando alguns estudos de adsorção de lipossomos em argila [Jaurand et al., 1983] e referências incidentais à adsorção de lipossomos em colunas de filtração em gel [Huang, 1969] ou a filtros de membrana [Schullery e Garzaniti, 1973].

Vesículas sonicadas de dipalmitoilfosfatidilcolina (DPPC) e fosfatidilinositol (PI) se rompem ao contatar bolinhas de vidro ocorrendo deposição lipídica sobre o vidro [Jackson, 1986]. Lipossomos formados por anfifilicos catiônicos do tipo dimetildialquilamônio recobrem superfícies de mica com uma camada de espessura correspondente a uma bicamada [Pashley, 1985; Pashley et al., 1986].

Bicamadas de cloreto de dioctadecildimetilamônio (DODAC) e de dihexadecilfosfato (DHP) recobrem microesferas de poliestireno de carga oposta [Carmona-Ribeiro e Midmore, 1992].

Por outro lado, fosfolipídios interagem com microesferas de poliestireno através de um mecanismo totalmente diferente [Carmona-Ribeiro e Herrington, 1993]. A interação hidrofóbica é dominante e ocorre primeiro o recobrimento da microesferas com uma monocamada fosfolipídica cujas cadeias hidrocarbônicas estão voltadas para a superfície hidrofóbica da microesferas e as cabeças polares estão voltadas para a água [Carmona-Ribeiro e Herrington, 1993].

Vesículas de DODAAc adsorvem com alta afinidade sobre látex sulfato [Tsuruta e Carmona-Ribeiro, 1996].

DODAB, DODAC e DODAAc adsorvem sobre um homopolímero hidrofóbico composto de poliestireno. $\mathrm{O}$ aumento da carga superficial, decorrente da adição de proporções crescentes de ácido metacrílico na composição do copolímero poli(estireno/metacrilato), promove um grau de orientação vertical 
crescente das cadeias hidrocarbônicas sobre este copolímero. [Lessa e CarmonaRibeiro, 1996].

Vesículas pequenas de asolecitina podem causar defloculação de látex sulfato, devido à adsorção de monocamada de asolecitina, com as cabeças polares voltadas para o ambiente aquoso [Carmona-Ribeiro e Lessa, 1999].

Isotermas de adsorção indicam que interação entre DODAC e sillica é forte devido à força de atração eletrostática e que uma bicamada adsorvida é provavelmente formada [Esumi et al., 1992].

Bicamadas fosfolipídicas podem ser depositadas sobre vidro, quartzo e superfícies de silício por transferência seqüencial de duas monocamadas pela técnica de Langmuir-Blodget. Medidas de difusão lateral de bicamadas de DPPC suportadas sobre lâminas de óxido de silício revelam duas temperaturas de transição de fase similares àquelas encontradas em sistemas multilamelares obtidas por diferentes técnicas [Tamm e McConnell, 1985].

Fusão e propagação de bicamadas de fosfolipídios sobre superfície de vidro foi investigada em função do $\mathrm{pH}$ e força iônica por Cremer e Boxer [Cremer e Boxer, 1999], sendo observado que fusão de vesículas negativas sobre o suporte negativo é favorecida por alta força iônica, e baixo $\mathrm{pH}$. Enquanto que para vesículas sem carga ou com carga positiva, há fusão sobre a superfície negativa sob qualquer condição experimental. Isso sugere que as interações de van der Waals e interação eletrostática governam o processo de fusão. Propagação de membrana sobre uma superfície planar é favorecida por baixo $\mathrm{pH}$, e o processo é dirigido por forças de van der Waals. Por outro lado, a propagação de membrana é impedida por alto $\mathrm{pH}$ ou pela rugosidade da superfície que impõe o fornecimento de energia para que a membrana possa se curvar. [Cremer e Boxer, 1999]. Quanto uma bicamada suportada é mecanicamente particionada por "ranhuras" na membrana em pH básico, barreiras à difusão lateral são formadas, o que previne a mistura entre duas regiões separadas. Diminuindo o $\mathrm{pH}$, é observado que a bicamada 
difunde pela fronteira da ranhura, permitindo a mistura entre regiões separadas [Cremer et al, 1999].

A aplicação de análise de impedância para construção de biosensores baseado em membranas lipídio / proteína suportadas foi explorada por Stelzle e colaboradores. Membranas lipídicas com alto grau de recobrimento de superfície $(99,5 \%)$ foram preparadas por dois métodos. Bicamadas de resistência muito alta foram formadas por deposição de uma monocamada de mercaptoalcanos covalentemente ligados sobre substrato de ouro e, subseqüente transferência de monocamada lipídica via transferência de monocamada utilizando a técnica de Langmuir-Blodgett. A preparação de membranas planares por fusão de vesículas sobre superfícies carregadas foi demonstrada. A monocamada negativamente carregada de carboximercaptanas foi primeiramente depositada sobre ouro, sobre o qual vesículas de $\mathrm{DODAB}$, positivamente carregadas, fundem espontaneamente, enquanto vesículas de dimiristoilfosfatidilglicerol (DMPG), negativamente carregadas, fundem após adição de $\approx 1 \mathrm{mM}$ de íons cálcio. Combinação de análise de impedância e espectroscopia de "surface plasmon" constitui uma ferramenta poderosa para a detecção de ligação do ligante ao seu receptor que está incorporado a uma membrana lipídica suportada [Stelzle et al, 1993].

Interações entre vesículas de $\mathrm{DODAB}$ e superfícies biológicas, como as superfícies celulares também foram estudadas sob o ponto de vista físico-químico. Vesículas catiônicas compostas por bicamadas de DODAB interagem com a superfície irregular carregada negativamente de Escherichia coli, bactéria Gramnegativa da família Enterobacteriaceae [Tápias et al, 1994; Sicchierolli et al., 1995]. DODAB induz floculação das bactérias para densidades numéricas altas (a partir de $10^{7}$ células por $\mathrm{mL}$ ) e ocorre morte celular em presença de DODAB em concentrações na faixa dos décimos de micromolar para qualquer densidade numérica de bactérias [Tápias et al, 1994; Sicchierolli et al, 1995]. 
Dentro do grupo dos compostos de amônio quaternário, moléculas similares ao DODAB têm ação germicida, sendo este fato conhecido desde 1935 [Domagk, 1935].

O efeito bactericida de DODAB foi avaliado para Eschericbia coli, Salmonella typhimurium, Pseudomonas aeruginosas e Staphylococcus aureus para estabelecer a ordem de suscetibilidade de diferentes espécies bacterianas ao $\mathrm{DOD} A \mathrm{~B}$ a uma concentração de células viáveis fixa $\left(2,5 \times 10^{7}\right.$ bactérias viáveis $\left./ \mathrm{mL}\right)$. Para as quatro espécies de bactérias, a suscetibilidade ao DODAB aumenta de E. coli a $S$. aureus na ordem acima [Campanha et al, 1999].

Látex recoberto com fosfolipídio oferece um ambiente propício para reconhecimento entre a toxina da cólera e o seu receptor (monosialogangliosídio GM1). Adsorção não-específica da antitoxina da cólera sobre a superfície de látex pode ser controlada por recobrimento do látex com fosfolipídio. Aumentando a concentração de dipalmitoilfosfatidilcolina na dispersão de látex, a adsorção nãoespecífica da antitoxina da cólera diminui [Sicchierolli e Carmona-Ribeiro, 1996].

Se minerais, metais, e polímeros podem ser usados como suporte para bicamadas, o reverso também é verdadeiro. Tubos de fosfolipídios, substratos de fosfolipídios carregados [Archibald e Mann, 1993], e surfactantes orgânicos iônicos [Bunker, et al., 1994] podem dirigir deposição de minerais orientando nucleação, crescimento e a morfologia final da espécie inorgânica [Firouzi et al., 1995].

Bicamadas de fosfatidilcolina de cadeia simples ou dupla (DPPC e DSPC) adsorvidas na interface silício/água foram preparadas e caracterizadas por Charitat e colaboradores. A segunda bicamada, chamada "bicamada livre", forma um sistema altamente hidratado acima do primeiro a cerca de 20 a 30 Angstrom. A reprodutibilidade da preparação foi possível devido a combinação das técnicas da Langmuir-Blodgett e Langmuir Schaeffer [Charitat et al, 1999]. 
Interação e agregação de vesículas de fosfatidilserina foram estudas em função da variação de espécies de cátion e sua concentração em suspensões de vesículas, variando-se também o tamanho das vesículas. Agregaçăo foi determinada por medidas de turbidimetria das suspensões de vesículas. Os resultados experimentais da agregação de vesículas induzida por cátions monovalentes foram explicados em termos de energia de interação entre duas vesículas, utilizando a teoria de DLVO, tanto para vesículas lipídicas grandes quanto para as pequenas. No entanto, os dados experimentais resultantes da agregação de vesículas induzida por cátions divalentes não foram explicados em termos da teoria de DLVO. Para explicar os resultados experimentais deste fenômeno de agregação, é necessário modificar a teoria, incluindo energias de interação de hidratação. A magnitude desta energia de interação de hidratação depende da natureza (hidrofobicidade) da superfície da membrana [Ohki e Ohshima, 1999].

A adesão entre vesículas catiônicas e membranas aniônicas suportadas sobre um substrato com uma carga superficial ajustável pelo $\mathrm{pH}$ foi reportado por Nardi e colaboradores. Através de métodos interferométricos, foi medida a tensão na membrana induzida pela adesão [Nardi et al, 1998].

Monocamadas de DPPC, suportadas via Langmuir-Blodgett, exibem estruturas densas em forma de trama enquanto monocamadas de DPPE suportadas são mais uniformes. Quanto uma segunda monocamada de lipídio é suportada sobre a primeira monocamada, a estrutura resultante da deposição de bicamada é fortemente dependente do acoplamento das monocamadas. No acoplamento de monocamadas de DPPC, a bicamada exibe domínios com extensões em forma de "dedo". As bicamadas muito mais uniformes foram obtidas quando o acoplamento de camadas de DPPC [Tamm et al, 1996].

Foi estudada por Kasbauer e colaboradores a formação de uma bicamada suportada sobre silica não porosa monodispersa, contendo lipídios catiônicos e zwiteriônicos por fusão de vesículas unilamelares pequenas sobre 
superfície sólida em baixas concentrações salinas usando a combinação de espectroscopia de reflexão total de infravermelho (ATR-IR) e NMR em deutério com microcalorimetria. Os dados sugerem que uma significante assimetria do lipídio catiônico entre as monocamadas externa e interna da bicamada resulta do prolongado tempo de interação do suporte sólido com as vesículas pequenas. Para vesículas pequenas compostas de DPPC/DHDAB (4:1) foi observado um enriquecimento na monocamada interna do componente catiônico de cerca de $200 \%$ quando comparado com a monocamada externa após 12 horas de interação. Isso sugere que o potencial eletrostático que surge da superfície é a força motora para a criação desta assimetria [Kasbauer et al, 1999].

\section{I.4.2 - Isotermas de adsorção}

O contato de uma substância tensoativa diluída em solução aquosa com uma grande superfície adsorbente, poderá levar a uma adsorção extensiva com uma redução contínua na concentração da solução. Para se ter uma superfície grande para adsorção, o sólido - que é chamado de adsorvente - deve ser finamente dividido. A partir de dados analíticos que descrevem a mudança de concentração na solução, assim como, o conhecimento da quantidade total de sólido da solução equilibrada, é possível determinar a quantidade de soluto adsorvido - que é chamada de adsorbato - por unidade de peso do sólido. Se a área específica do sólido é conhecida, então os resultados podem ser expressos como quantidade adsorvida por unidade de área. Esses estudos são geralmente conduzidos a temperatura constante, e os resultados - que relacionam a quantidade de material adsorvido com a concentração de equilíbrio em solução - definem uma isoterma de adsorção [Hiemenz, 1986]. 


\section{I.4.2.1 - Tipos de isotermas}

Isotermas para adsorção de solutos orgânicos são divididas em quatro classes principais, de acordo com a natureza do coeficiente angular da porção inicial da curva.

As principais classes são: (1) curvas $S$, indicativas de orientação vertical de moléculas do adsorbato na superfície; (2) curvas L, isotermas normais ou de "Langmuir", usualmente indicativas de adsorbatos "deitados" sobre a superfície, ou às vezes, adsorbatos iônicos orientados verticalmente com atração intermolecular particularmente forte; (3) curvas H, ("alta afinidade") (começando de um valor positivo no eixo de concentração adsorvida sobre o sólido), freqüentemente resultando da adsorção de solutos como micelas iônicas, ou de troca iônica de altaafinidade com íons de baixa-afinidade; (4) curvas C ("partição constante"), curva linear, resultando da adsorção de solutos que adsorvem no sólido mais rapidamente do que o solvente [Giles et al., 1960].

Os subgrupos destas classes estão arranjados de acordo com a forma das curvas depois do ponto de origem e da posição do platô. Assim, se as moléculas do soluto que estão adsorvidas na nova superfície apresentam baixa atração por mais moléculas, a curva apresenta um longo platô. Se as moléculas que estão adsorvidas na superfície apresentam alta afinidade por mais soluto, a curva cresce continuamente e não apresenta platô. (figura I.4.2.1). 


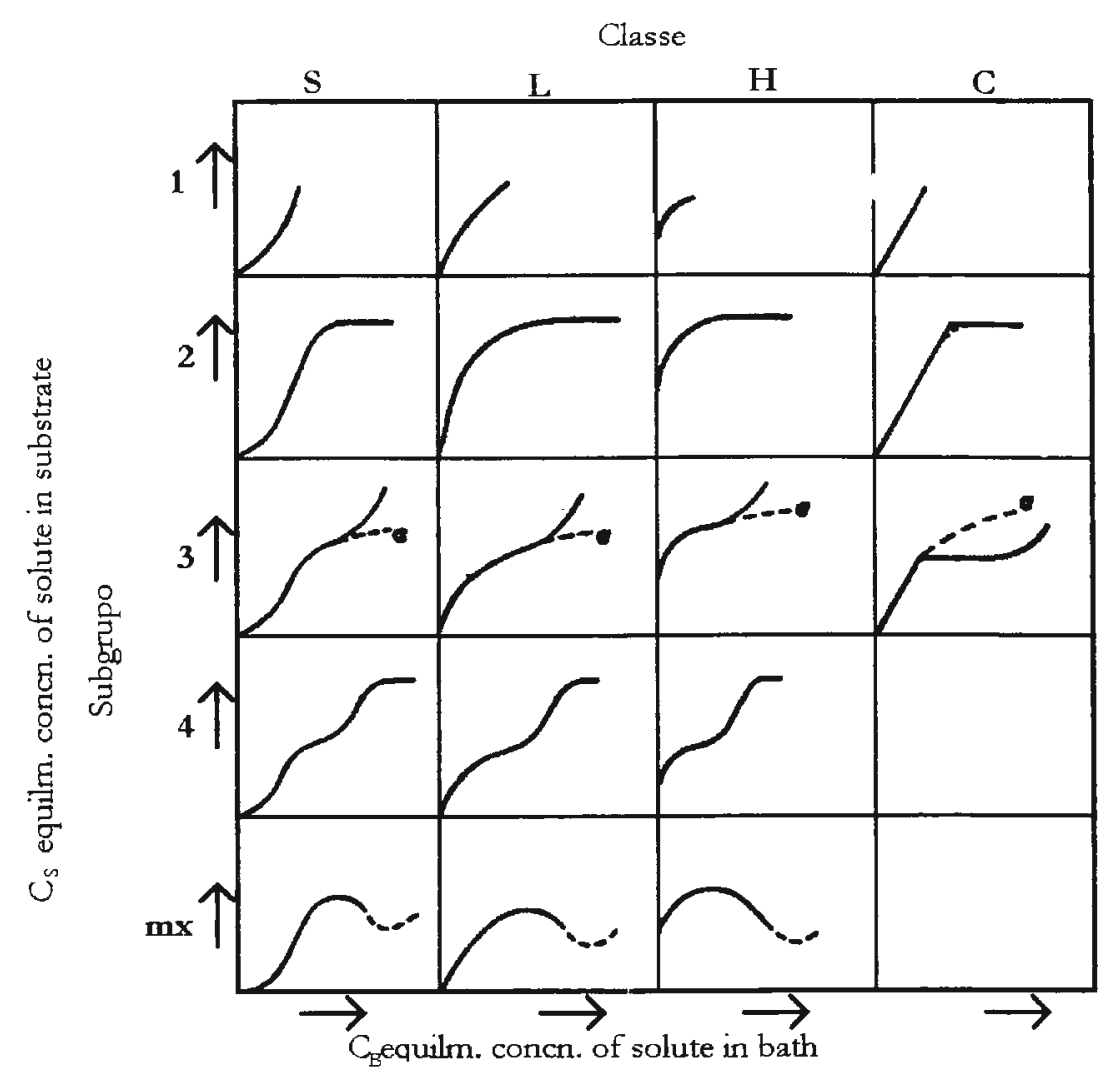

Figura I.4.2.1 - Sistema de classificação de isotermas.

As curvas $\mathrm{L}$ são as mais conhecidas; na verdade a curva L2 ocorre em provavelmente na maioria dos casos de adsorção a partir de soluções diluídas.

A inclinação inicial depende da velocidade de mudança do sítio de adsorção com aumento no soluto adsorvido. Para haver adsorção de uma dada quantidade adicional do soluto, a concentração do soluto deve ser aumentada. Na parte inicial das curvas S, no entanto, a condição oposta é aplicada, e quanto mais soluto já está adsorvido, mais fácil serem adsorvidas quantidades adicionais. Isso implica em uma associação lado a lado entre as moléculas adsorvidas ou adsorção cooperativa.

$\mathrm{Na}$ prática, a curva $\mathrm{S}$ usualmente aparece quando três condições são preenchidas: a molécula do soluto (a) é monofuncional, (b) tem moderada atração intermolecular, causando o empacotamento vertical na camada adsorvida e (c) encontra forte competição, pelos sítios do substrato, a partir de moléculas do 
solvente ou de outras espécies adsorvidas. Essa isoterma aparentemente indica a tendência de moléculas de adsorbatos se associarem, ao invés de se manterem em unidades isoladas.

Nas curvas L, a curvatura inicial mostra que quanto mais sítios são preenchidos torna-se mais difícil a adsorção de moléculas do soluto em novos sítios. Isso implica que as moléculas adsorvidas não estão verticalmente orientadas, ou que não existe uma forte competição do solvente. Os tipos de sistemas que apresentam este tipo de curva de fato preenchem essas condições, possuindo as seguintes características: (i) as moléculas adsorvidas são prefetencialmente adsorvidas deitadas; (ii) se adsorvidas verticalmente as moléculas sofrem uma pequena competição pelo solvente. Exemplos de (ii) são: (a) sistemas com solutos e substratos altamente polares, (b) sistemas com substâncias iônicas monofuncionais com atração intermolecular muito forte. É possível que nesses casos (sistemas b), os íons adsorvidos possam se associar em aglomerados muito grandes antes da adsorção acontecer.

As curvas $H$ são um caso especial da curva $L$, em que o soluto tem tão alta afinidade pela superfície, que em soluções diluídas é completamente adsorvido, ou pelo menos, não permanece em quantidades mensuráveis na solução remanescente. A parte inicial da isoterma é vertical. As espécies adsorvidas são, freqüentemente unidades grandes, isto é, micelas iônicas ou moléculas poliméricas, mas às vezes elas são íons aparentemente simples que trocam com outros íons de afinidade muito menor pela superfície. Para altíssimas afinidades, a curva é uma linha horizontal.

Nas curvas C, os sítios de adsorção mantêm-se constantes em todas as concentrações até a saturação. A curva $C$ é caracterizada por partição constante do soluto entre solução e substrato, diretamente até a adsorção máxima possível, onde há uma mudança abrupta no platô horizontal. 
As condições que favorecem o aparecimento de curva $C$ são: (a) um substrato poroso com moléculas flexíveis e regiões com diferentes graus de cristalinidade, e um soluto com (b) mais alta afinidade pelo substrato do que pelo solvente e com (c) melhor poder de penetração, em virtude da condição (b) e da geometria molecular, nas regiões cristalinas do substrato.

Fundamentalmente, a linearidade mostra que os números de sítios para adsorção mantêm-se constantes; isto é, quanto mais soluto é adsorvido, mais sítios devem ser criados. Uma isoterma linear indica que o soluto está adsorvendo em regiões inacessíveis ao solvente, ou seja, há excesso de sítios disponíveis para a adsorção.

\section{I.4.2.2 - Modelo de Langmuir}

Uma isoterma que é fácil de compreender teoricamente e é quase sempre aplicável a dados experimentais é a isoterma de Langmuir.

Nesta teoria é suposto que uma solução em que ambos solvente (componente 1) e soluto (componente 2) têm moléculas que ocupam a mesma área ao adsorverem à superfície. A adsorção do soluto pode então ser esquematicamente representada pela seguinte equação:

solvente adsorvido+soluto em solução $\leftrightarrows$ soluto adsorvido+solvente em solução

A constante de equilíbrio para essa reação pode ser escrita como

$$
k^{\prime}=\frac{a_{2}^{s} a_{1}^{b}}{a_{1}^{s} a_{2}^{b}}
$$

onde $a$ representa a atividade das espécies e o sobrescrito $s$ e $b$ significam superfície e seio da solução, respectivamente.

Assumindo que a solução na superfície bidimensional é ideal, podemos substituir atividade na superfície por fração molar na superfície $x^{s}$. 


$$
k^{\prime}=\frac{x_{2}^{s} a_{1}^{b}}{x_{1}^{s} a_{2}^{b}}
$$

Desde que a superfície contenha apenas 2 componentes, $x_{1}^{s}+x_{2}^{s}=1$ podemos escrever:

$$
k^{\prime}=\frac{x_{2}^{s} a_{1}^{b}}{\left(1-x_{2}^{s}\right) a_{2}^{b}}
$$

A equação I.4.2.2.3 pode ser rearranjada para obtermos

$$
x_{s}^{2}=\frac{k^{\prime} a_{2}^{b} / a_{1}^{b}}{k^{\prime} a_{2}^{b} / a_{1}^{b}+1}
$$

Em soluções diluídas a atividade do solvente é essencialmente constante, então a relação $k^{\prime} / a_{1}^{b}$ pode ser definida como sendo igual a uma nova constante $k$, assim, a equação 1.4.2.2.4 torna-se:

$$
x_{s}^{2}=\frac{k a_{2}^{b}}{k a_{2}^{b}+1}
$$

Essa é uma forma da isoterma de adsorção de Langmuir.

Uma forma equivalente da equação de Langmuir expressa em variáveis ligeiramente diferentes é obtida multiplicando ambos $x_{1}^{s}$ e $x_{2}^{s}$ na equação I.4.2.2.2 pela área total da superfície. Como foi postulado que tanto o solvente como o soluto ocupam áreas iguais sobre a superfície, então, $x_{i}^{s} A$ é igual a fração da superfície ocupada pelo componente i, $\theta_{1}$. Desde que $\theta_{1}+\theta_{2}=1$, a relação $\theta_{1} / \theta_{2}$ rearranja da mesma maneira que $x_{2}^{s} / x_{1}^{s}$ para dar

$$
\theta_{2}=\frac{k a_{2}^{b}}{k a_{2}^{b}+1}
$$


Nesta forma a equação de Langmuir mostra como a fração dos sítios de adsorção da superfície ocupada pelo soluto aumenta com a atividade do soluto em soluções com concentrações crescentes.

Dois casos limites são de especial interesse:

1. Em condições de diluição infinita $a \rightarrow 0$, a equação acima torna-se:

$\theta=k a$

2. Se $k a \gg>1$, a equação de Langmuir torna-se:

$\theta=1$

A equação resultante do primeiro caso limite mostra que $\theta$ aumenta linearmente com uma inclinação inicial igual a $k$. Em altas concentrações, a equação resultante do segundo caso limite indica que é alcançada a saturaçăo da superfície com o soluto adsorvido.

Experimentalmente, não é medida a fração de números de sítios contendo soluto adsorvido diretamente, e sim, o número de moles do soluto adsorvido por unidade de peso do adsorbente, $n_{2}^{s} / w$, ou o número de moles por unidade de área de adsorbente, $n_{2}^{s} / A$. Essas quantidades são relacionadas. através da seguinte equação

$$
\frac{n_{2}^{s}}{A} A_{s p}=\frac{n_{2}^{s}}{w}
$$

onde $A_{s p}$ é a área específica do adsorbente. A fração de área recoberta é relacionada a essas quantidades como segue:

$$
\theta=\frac{n_{2}^{s}}{A} N_{A} \sigma^{0}=\frac{n_{2}^{s} N_{A} \sigma^{0}}{w A_{s p}}
$$


onde $N_{A}$ é o número de Avogadro e $\sigma^{0}$ é a área ocupada por molécula. O nível em que adsorção de saturação ocorre pode ser identificado $\operatorname{com} \theta=1$, assim a equação I.4.2.2.10 mostra valores de saturação de ordenadas usuais como sendo:

$$
\begin{gathered}
\left(\frac{n_{2}^{s}}{w}\right)_{s a t}=\frac{A_{s p}}{N_{A} \sigma^{0}} \\
\text { ou } \\
\left(\frac{n_{2}^{s}}{A}\right)_{s a t}=\frac{1}{N_{A} \sigma^{0}}
\end{gathered}
$$

Desde que a derivação completa da isoterma de Langmuir assuma soluções diluídas, a concentração $c$ do soluto é utilizada no lugar de atividade na apresentação de resultados experimentais.

A equação de Langmuir pode ser escrita em sua forma linerarizada:

$$
m\left(\frac{n_{2}^{s}}{w}\right)=\frac{(m / b) c}{(m / b) c+1}
$$

Onde $m$ e $m / b$ são simplesmente constantes empíricas. Um método para obter os valores numéricos para essas constantes a partir de dados experimentais é obtido rearranjando a equação I.4.2.2.13 da seguinte forma:

$$
\frac{c}{n_{2}^{s} / w}=m c+b
$$

Essa forma sugere que um gráfico de $c /\left(n_{2}^{s} / w\right)$ versus $c$ gera uma linha reta de coeficiente angular $m$ e intercepto $b$.

Se o sistema experimental obedece ao modelo, então aos valores de $m$ e $b$ podem ser atribuídos significados físicos, comparando a equação I.4.2.2.13 com as equações I.4.2.2.6 e I.4.2.2.10: 


$$
m=\frac{N_{A} \sigma^{0}}{A_{s p}}
$$

$\mathrm{e}$

$$
\frac{m}{b}=k
$$

Eq. I.4.2.2.16

\section{I.5 - Merocianina 540}

MC540 é um marcador anfipático fotosensível muito utilizado em aplicações médicas [Sieber et al, 1984; Sieber, 1987].

A figura I.5.1 mostra a estrutura química da merocianina 540.<smiles>CCCCCCN1C(=CC=CC=C2C(O)N(CCC)C(=S)N(CCC)C2O)Oc2ccccc21</smiles>

Figura I.5.1 - Estrutura química da merocianina 540

Como MC540 é fotoexcitado por luz visível em comprimento de onda apropriado, MC540 pode inativar células leucêmicas, linfomas, neuroblastomas e células infectas por vírus [Sieber et al, 1984; Easton, et al, 1978; O’Brien, et al, 1990]. Apesar desses usos, tanto o mecanismo de ação, quanto à variação de afinidade por diferentes tipos de células ainda estão sob discussão.

Experimentos com lipossomos artificiais mostraram que o marcador liga-se preferencialmente em lipossomos compostos por lipídios insaturados [Williamson et al, 1981, 1983]. MC540 é mais ligada a vesículas em temperaturas acima da temperatura de transição de fase. Se os lipossomos possuem a mesma composição 
química, mas são de dimensões diferentes, MC540 irá ligar preferencialmente em lipossomos menores, isto é, os que possuem maior curvatura e conseqüentemente cabeça polares mais separadas [Williamson et al, 1981, 1983].

Segundo alguns trabalhos, o espectro de absorção de MC540 é quase independente do $\mathrm{pH}$ entre 3 e 8 [Pohl, 1976]. Por outro lado Šikurová e Čunderlíková reportaram que a forma espectral e as posições de picos de MC540 em água permanecem praticamente inalteradas em valores de $\mathrm{pH}$ entre 1,7 e 7,6 a $23 \pm 2{ }^{\circ} \mathrm{C}$. A diminuição do $\mathrm{pH}$ de 5,5 para 1,7 causa somente uma diminuição reversível do espectro de absorção e quenching da intensidade de fluorescência, sem o aparecimento de nenhuma outra nova banda espectral. O marcador precipita com o aumento da acidez. O aumento do pH acima de 7,6 em solução aquosa de MC540 resulta na formação irreversível de uma nova banda larga nos espectros de absorção (a $390 \mathrm{~nm}$ ) e fluorescência (a $500 \mathrm{~nm}$ ). Essa mudança irreversível pode ser devido ao ataque de íons hidroxila às moléculas de merocianina [Šikurová e Čunderlíková, 1997].

Os valores do coeficiente de absortividade molar de MC540 em água e em benzeno são dados na tabela I.5.1.

Tabela I.5.1 - Coeficientes de absortividade molar de MC540 em água e em benzeno.

\begin{tabular}{lcc}
\hline Meio & $\begin{array}{c}\text { Comprimento de onda } \\
\mathrm{nm}\end{array}$ & $\begin{array}{c}\text { Coeficiente de absortividade molar } \\
\mathrm{mol}^{-1} \mathrm{~cm}^{-1}\end{array}$ \\
\hline Água & 500 & $6,1 \times 10^{-4 \mathrm{a}}$ \\
Água & 530 & $5,4 \times 10^{-4 \mathrm{a}}$ \\
Benzeno & 565 & $18,3 \times 10^{-4 \mathrm{~b}}$ \\
\hline
\end{tabular}

a Šikurová e Čunderlíková, 1997 ㅎ Lelkes e Miller, 1980

MC540 localizada como monômero em sítios hidrofóbicos de bicamada lipídica apresenta uma absorção máxima de luz em $565 \mathrm{~nm}$. Como dímero apresenta uma absorção máxima em $530 \mathrm{~nm}$, decorrente da sua localização na regia 
polar aquosa da bicamada, e MC540 em água apresenta absorção máxima em 500 nm [Lelkes e Miller, 1980].

A constante de dimerização da merocianina 540 foi utilizada na determinação nas diferenças de empacotamento de bicamadas em vesículas de lipídios de tamanhos diferentes [Arroyo et al., 1998].

MC540 também pode ser utilizada para detectar defeitos hidrofóbicos em bicamadas causados pela presença de $\mathrm{NaCl}$ em concentrações de até $50 \mathrm{mM}$ [Carmona-Ribeiro, 1993]. 


\section{II - Materiais e Métodos}

\section{II.1 - Obtenção de anfifílicus e preparação de vesículas}

Fosfatidilcolina (PC), dipalmitoilfosfatidilcolina (DPPC), dihexadecilfosfato de sódio (DHP) e brometo de dioctadecildimetilamônio (DODAB) foram obtidos da Sigma e utilizados sem purificação prévia.

Vesículas unilamelares pequenas de PC e DPPC foram obtidas por injeção etanólica de PC ou DPPC em tampão 2-(hidroximetil)-2-amino-1,3-propanodiol (Tris) 10mM, ou 4-(2-hidroxietil)-1-ácido piperzinoetanosulfônico (HEPES) 10 $\mathrm{mM}, \mathrm{pH} 6,4 ; 7,4$ ou 8,$2 ;$ ou $\mathrm{H}_{2} \mathrm{O}$ com posterior diálise para eliminação de etanol [Bastzri e Korn, 1973; Kremer et al., 1977]. As vesículas foram posteriormente centrifugadas para eliminação de possíveis vesículas multilamelares formadas [Rapuano e Carmona-Ribeiro, 1997].

Vesículas unilamelares grandes de PC ou DPPC foram obtidas por injeção etérea de PC ou DPPC em tampão Tris ou HEPES $10 \mathrm{mM}$, pH 6,4; 7,4; 8,2 ou água [Deamer e Bangham, 1976].

Foram preparadas também vesículas de DPPC utilizando o método de dispersão de filme [New, 1994].

Vesículas unilamelares de DODAB e DHP foram obtidas por sonicação em $\mathrm{H}_{2} \mathrm{O}$, Tris ou HEPES, $10 \mathrm{mM}, \mathrm{pH}$ 6,4; 7,4 ou 8,2, com posterior centrifugação para remoção de partículas de titânio adicionadas à solução devido ao sonicador, e remoção de eventuais vesículas multilamelares formadas [Fendler, 1980; Mortara et al., 1978].

Vesículas unilamelares grandes de DODAB foram obtidas por vaporização clorofórmica de DODAB em tampão Tris 10 mM, HEPES 10 mM, pH 6,4; 7,4; 8,2 ou água [Carmona-Ribeiro e Chaimovich, 1983]. 
A concentração de vesículas de PC, DPPC ou DHP foi determinada através de dosagem de fosfato [Rouser et al. 1970]. Neste método as amostras são secas em estufa $\left(\sim 100{ }^{\circ} \mathrm{C}\right)$, em seguida são adicionados $0,3 \mathrm{~mL}$ de ácido perclórico concentrado, sendo em seguida colocadas em banho a $180^{\circ} \mathrm{C}$ por 4 horas.

Após a digestão das amostras, adiciona-se $1 \mathrm{~mL}$ de água e $0,4 \mathrm{~mL}$ de molibdato de amônio, agita-se em seguida. Depois se adiciona em cada amostra 0,4 $\mathrm{mL}$ de ácido ascórbico e agita-se novamente.

As amostras são colocadas em banho de água fervente por 5 minutos e depois é lida a absorbância do complexo formado entre o molibdato e o fosfato a $795-797 \mathrm{~nm}$.

A concentração de vesículas de DODAB em $\mathrm{H}_{2} \mathrm{O}$ foi determinada por microtitulação com $\mathrm{Hg}\left(\mathrm{NO}_{3}\right)_{2}$ utilizando como indicador visual a difenilcarbazona [Schales e Schales, 1941]. Também é adicionado etanol absoluto à dispersão de vesículas para garantir seu rompimento.

A concentração de vesículas em tampão Tris ou HEPES foi obtida através de solubilização do complexo Orange G/DODAB em micelas neutras utilizando as vesículas preparadas em água como padrão [Stelmo et al., 1987]. O complexo formado pelo anfifilico catiônico com Orange $G$ é solubilizado por micelas neutras de Brij 35 e a variação da absorbância devido à formação do complexo comparada com a de padrão. $\mathrm{O}$ método detecta concentrações da ordem de $10^{-6} \mathrm{~mol} / \mathrm{L}$.

Em todas as preparações foi utilizada água MilliQ.

\section{II.2 - Obtenção e caracterização das partículas de sílica}

As partículas de silica hidrofilica (AEROSIL OX-50) foram obtidas da DEGUSSA S/A. A área superficial específica destas partículas foi determinada por titulação potenciométrica em meio de $20 \%$ de $\mathrm{NaCl}$ com NaOH 0,1 M [Sears Jr., 1956] e por adsorção de $\mathrm{N}_{2}$ (BET) [Hiemenz, 1986; Brunauer et al., 1938]. A determinação de adsorção de nitrogênio (BET) foi gentileza do professor Dr. 
Miguel Jafelicci Júnior do Instituto de Química da Universidade Estadual Paulista (UNESP) - Campus de Araraquara.

As partículas utilizadas possuem área superficial específica de $25,98 \mathrm{~m}^{2} / \mathrm{g}$ (BET), em bom acordo com a área superficial específica obtida por titulação potenciométrica, que foi $27 \mathrm{~m}^{2} / \mathrm{g}$. A área superficial específica fornecida pela Degussa S/A para estas partículas é de $50 \pm 15 \mathrm{~m}^{2} / \mathrm{g}$. Esta grande discrepância entre os valores de área superficial específica obtidas por BET e por titulação potenciométrica, e o valor de área superficial específica fornecida pela Degussa S/A mostra a tendência dessas partículas agregarem.

\section{II.3 - Obtenção das superfícies planares de $\mathrm{SiO}_{2}$}

As superfícies planares de $\mathrm{SiO}_{2}$ foram obtidas por oxidação térmica rápida de lâminas de silício monocristalino [Chiou, et al., 1990] tendo a espessura de $\mathrm{SiO}_{2}(30$ $\mathrm{nm})$ determinada por elipsometria por cortesia do Laboratório de Sistemas Integráveis, EPUSP.

II.4 -Determinação de isotermas de adsorção de anfifílicos a partir de vesículas sobre partículas de sílica.

A interação entre vesículas e partículas foi induzida pela adição de vesículas às partículas e vortexação por alguns minutos em eppendorf fechado. As misturas de silica e vesículas foram termostatizadas a uma temperatura acima da temperatura de transição de fase das bicamadas por uma hora. As temperaturas utilizadas foram as seguintes: $25^{\circ} \mathrm{C}$ para $\mathrm{PC} ; 42^{\circ} \mathrm{C}$ para $\mathrm{DODAB} ; 65^{\circ} \mathrm{C}$ para DPPC e $72^{\circ} \mathrm{C}$ para DHP.

Todas as misturas de $1 \mathrm{~mL}$ continham $1 \mathrm{mg} / \mathrm{mL}$ de silica, o que representa uma área superficial total de $2,60 \times 10^{-2} \mathrm{~m}^{2}$.

Após o tempo de interação de 1 hora, as misturas foram centrifugadas a $14000 \mathrm{rpm}$ por uma hora a $15^{\circ} \mathrm{C}$ para separar partículas de vesículas. O 
sobrenadante foi utilizado para determinar a concentração de PC, DPPC, DHP ou DODAB. As isotermas de adsorção dos fosfolipídios ou anfifílicos sintéticos sobre as partículas foram obtidas a partir dessa determinação analítica e da área superfícial específica e massa das dispersões de silica em cada mistura.

As isotermas que obedecem ao modelo de Langmuir foram linearizadas utilizando a seguinte equação:

$$
\frac{c}{x / m}=\frac{c}{(x / m)_{\max }}+\frac{1}{k(x / m)_{\max }}
$$

onde $x / m$ é o número de moles de anfifilico adsorvidos em $m$ metros quadrados de silica, $c$ é a concentração de anfifilico no sobrenadante e $k$ é a constante de afinidade entre o anfifilico e a sillica [ackson et al., 1986].

A partir do gráfico de $\frac{c}{x / m}$ versus $c$ podemos obter a adsorção máxima pelo coeficiente angular e a constante de afinidade pela coeficiente linear da reta obtida.

A tabela II.4.1 mostra o protocolo utilizado para determinação das isotermas de adsorção. 
Tabela II.4.1 - Protocolo para determinação das isotermas de adsorção entre PC, DPPC ou DODAB $2 \mathrm{mM}$ com dispersão de sílica em água ou tampão Tris ou HEPES $10 \mathrm{mM}, \mathrm{pH} 6,4 ; 7,4$ ou 8,2.

\begin{tabular}{lccc}
\hline Número da mistura & $\begin{array}{c}\text { Volume de dispersão } \\
\text { de vesícula } \\
(\mu \mathrm{L})\end{array}$ & $\begin{array}{c}\text { Volume de } \\
\text { tampão }\end{array}$ & $\begin{array}{c}\text { Volume de } \\
\text { dispersão de sílica }\end{array}$ \\
\hline 1 & 25 & $(\mu \mathrm{L})$ & $(\mu \mathrm{L})$ \\
2 & 50 & 475 & 500 \\
3 & 75 & 450 & 500 \\
4 & 100 & 425 & 500 \\
5 & 125 & 400 & 500 \\
6 & 150 & 375 & 500 \\
7 & 200 & 350 & 500 \\
8 & 225 & 300 & 500 \\
9 & 250 & 275 & 500 \\
10 & 300 & 250 & 500 \\
11 & 325 & 200 & 500 \\
12 & 350 & 175 & 500 \\
13 & 400 & 150 & 500 \\
14 & 425 & 100 & 500 \\
15 & 450 & 75 & 500 \\
16 & 500 & 50 & 500 \\
\hline
\end{tabular}

A tabela II.4.2 mostra a planilha de cálculo utilizada para calcular a quantidade de moléculas de fosfolipídio adsorvida por metro quadrado de sillica. 


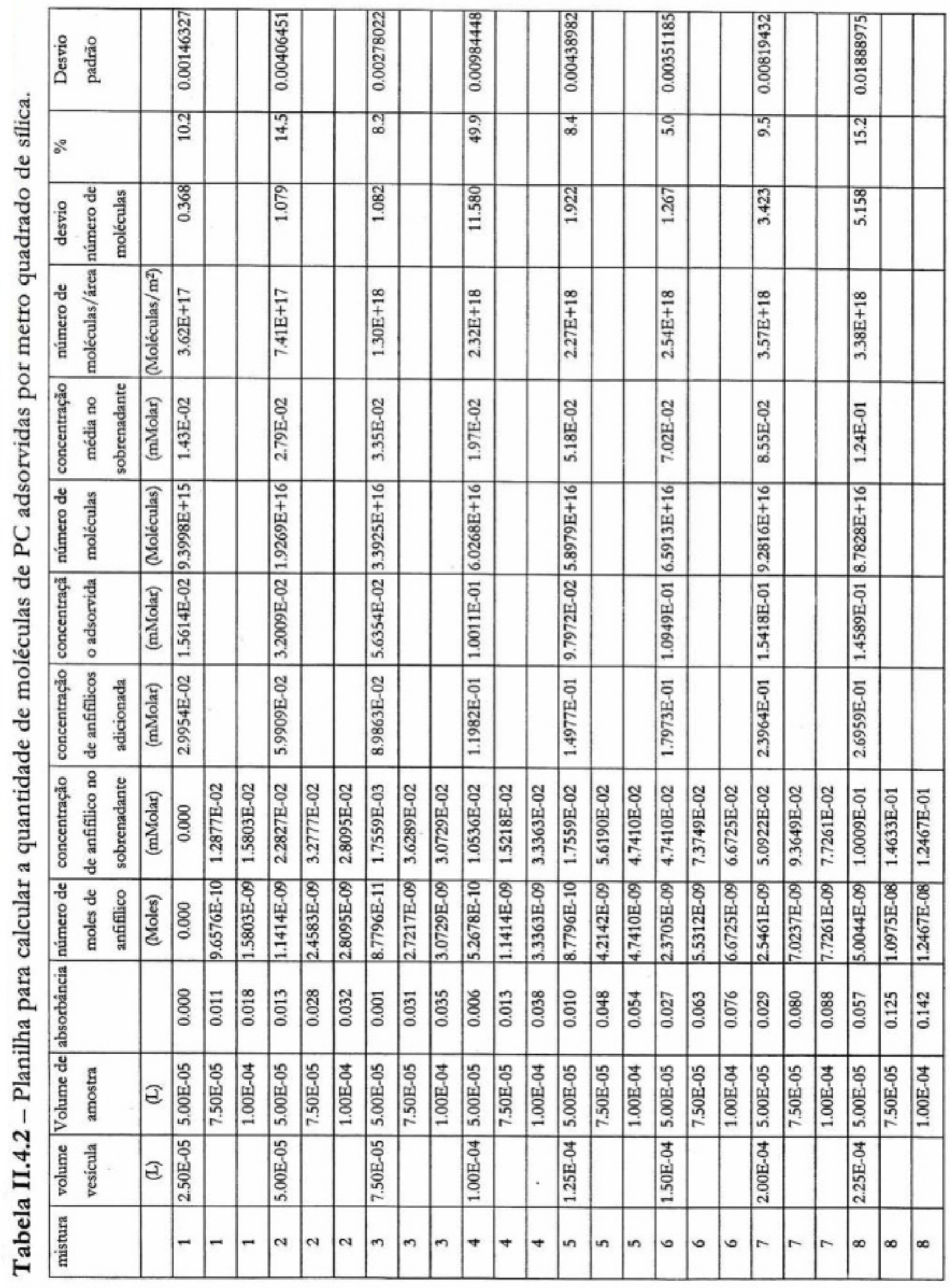




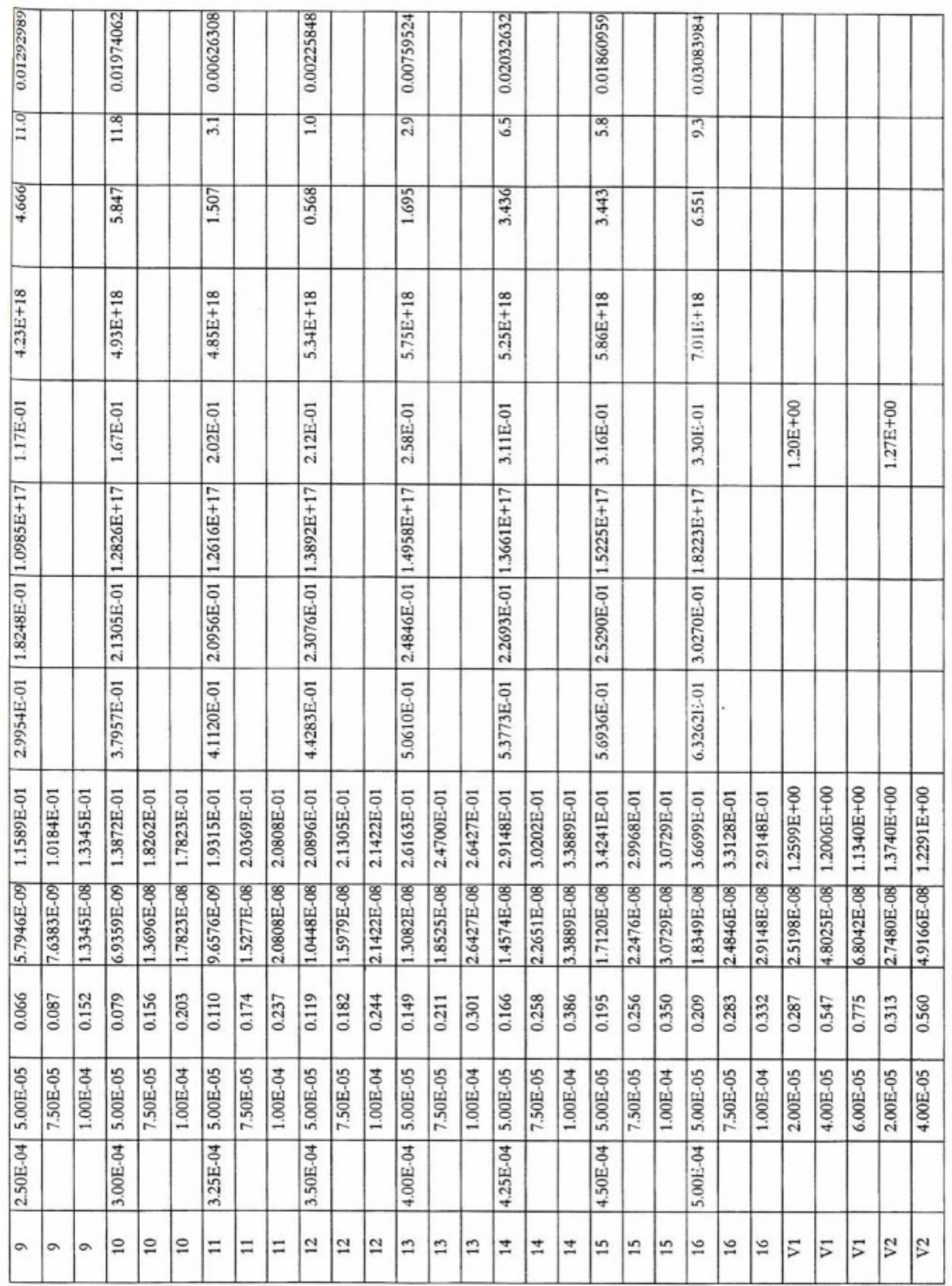


옹

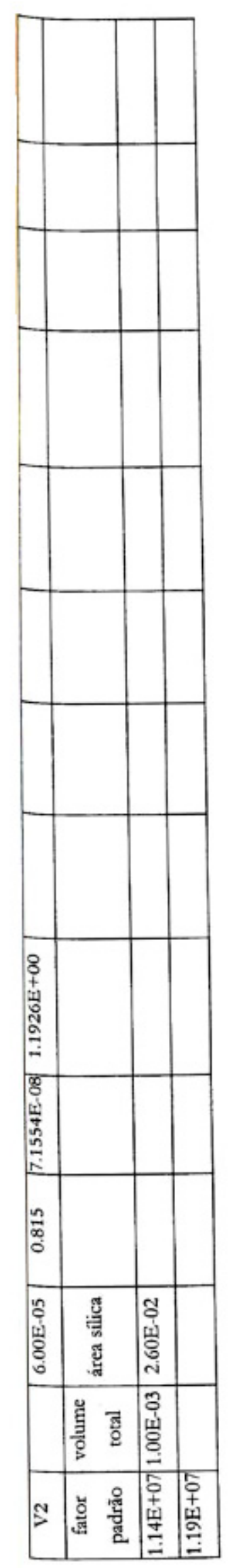




\section{II.5 - Verificação de eventual interdigitação de vesículas fosfolipídicas}

usando merocianina 540 (MC540).

Às vesículas de DPPC, preparadas pelo método de dispersão de filme foi adicionado etanol para se obter uma concentração final de etanol de 2,0 mols/L, concentração esta que causa a interdigitação da membrana [Komatsu e Rowe, 1991]. A esta mistura foi adicionada MC540 (concentração final: $10^{-5}$ molar) e então foi registrado o espectro óptico entre 400 e $600 \mathrm{~nm}$, utilizando como branco uma dispersão de mesma concentração de vesículas e etanol, sem MC540, utilizando um espectrofotômetro Hitachi U2000 de duplo feixe.

Todos os espectros foram normalizados para absorbância zero em $600 \mathrm{~nm}$ para evitar erro decorrente de diferença de turbidez e espalhamento de luz pelas vesículas [Arroyo et al., 1998].

\section{II.6 - Determinação do efeito de partículas de $\mathrm{SiO}_{2}$ sobre os espectros} de absorção de luz pela MC540 incorporada em membranas lipídicas.

Para verificar se as partículas de $\mathrm{SiO}_{2}$ influenciam os espectros de absorção de luz pela MC540 incorporada a de vesículas, foi seguida a cinética de absorção de luz pela MC540 a $565 \mathrm{~nm}$ por 1 hora em presença de vesículas e ausência de partículas de silica, depois foi seguida a cinética de absorção de luz pela MC540 em presença de vesículas e partículas de $\mathrm{SiO}_{2}$. A concentração de lipídios na mistura é aquela que corresponderia à adsorção de bicamada sobe as partículas de silica $\left(0,026 \mathrm{~m}^{2}\right)$ pelas isotermas de adsorção. Ambas cinéticas foram registradas utilizando como branco uma dispersão vesicular de mesma concentração, sem MC540. Em todas as cinéticas a concentração final de MC540 era de $10^{-5} \mathrm{mols} / \mathrm{L}$.

O método é baseado assumindo-se que as moléculas de marcador que ficam oclusas entre a particular sólida e a bicamada depositada não absorvem a luz incidente. Como controle para redução de absorção espontânea ocorrendo da incorporação do marcador à superfície da bicamada, a absorbância a $565 \mathrm{~nm}$ foi 
obtida em função do tempo para amostra contendo somente vesículas e marcador, na ausência de partículas. Também, qualquer efeito que as partículas de silica pudessem ter sobre a absorção de luz do marcador foi controlado a partir de cinética para somente marcador e partículas. A porcentagem de deposição de bicamada foi calculada a partir da redução absorbância final, com o instante final sendo 60 minutos após a adição de partículas. A absorbância a $565 \mathrm{~nm}$ obtida pelo marcador depois de 1 hora de equilibração com vesículas será chamada de $A_{v}$. A absorbância a $565 \mathrm{~nm}$ obtida pelo marcador depois de 1 hora de equilibração com vesículas que foram adicionadas partículas no instante zero será chamada de $A_{v+p}$. A redução de absorbância será: $\Delta A=A_{v}-A_{v+p}$. Se toda a superfície externa incorporada com marcador for depositada como uma bicamada recobrindo as partículas, a redução total de absorbância $\Delta \mathrm{A}$ deverá ser máxima e igual a $A_{\mathrm{v}}$. Se as vesículas não interagem com as partículas de silica, não deverá ser observada redução e $\Delta \mathrm{A}$ deverá ser igual a zero. Se uma fração da densidade numérica total de vesículas estiver sendo usada para recobrir as partículas, a porcentagem de redução de absorbância será $100 \Delta \mathrm{A} / \mathrm{A}_{\mathrm{v}}$. Desde que o uso de todas as vesículas para recobrir partículas deverá requerer todas as moléculas de lipídios na dispersão e nós sabemos a quantidade total de lipídios em cada amostra, vamos dizer $\mathrm{n}$ moléculas, podemos assumir que uma redução de absorbância igual à $A_{v}$ é equivalente a empregar todas as moléculas de lipídios, isto é, n moléculas de lipídios para recobri a superfícies das partículas. Então, uma redução de absorbância igual a $\Delta \mathrm{A}$ irá requerer $\mathrm{n} \Delta \mathrm{A} / \mathrm{A}_{\mathrm{v}}$ moléculas de lipídio e a partir desta podemos obter facilmente o número total de moléculas de lipídios que adsorveram por $\mathrm{m}^{2}$ de silica, em moléculas por metro quadrado de silica. A proporção de vesículas e partículas nas misturas foi estabelecida a partir da menor quantidade de lipídio necessária para atingir a adsorção máxima nas isotermas de adsorção para lipídios a partir de vesículas sobre partículas de sílica. 


\section{II.7 - Determinação da tensão superficial de dispersões de vesículas.}

As dispersões de vesículas tiveram suas tensões superficiais determinadas utilizando o método clássico do anel de Du Nouy [Hiemenz, 1986], utilizando-se o Dynometer. Neste método mede-se a força necessária para desprender um anel de platina da superfície do líquido, suspendendo-se o anel, que está pendurado a um braço conectado a uma balança.

Antes de se determinar a tensão superficial do sistema em estudo o Dynometer deve ser calibrado através de um líquido, cuja tensão superficial seja próxima da tensão superficial do sistema em estudo. Além do mais, devido à forte dependência da tensão superficial com a temperatura, a medida deve ser feita em um ambiente cuja temperatura não varie. Neste trabalho o líquido utilizado para calibrar o Dynometer foi água Milli-Q a $25^{\circ} \mathrm{C}$.

\section{II.8 - Determinação do ângulo de contato dinâmico de superfície} planar de $\mathrm{SiO}_{2}$ em presença de dispersões de vesículas.

Antes de cada interação a superfície de $\mathrm{SiO}_{2}$ foi limpa através de fervura por 20 minutos, numa mistura de $1 \mathrm{NH}_{4} \mathrm{OH}: 1 \mathrm{H}_{2} \mathrm{O}_{2}: 5 \mathrm{H}_{2} \mathrm{O}$.

A partir dos dados de tensão superficial e determinação da massa em função da profundidade de imersão de lâminas de $\mathrm{SiO}_{2}$ sendo imersas e emersas de uma dispersão de vesículas a uma velocidade de $1,5 \mathrm{~mm} / \mathrm{min}$, após interação por 1 hora, foram obtidos os ângulos de contato dinâmico de avanço ou de recesso, respectivamente, usando um Dynometer (BYK Gardner, Alemanha) [Salay, 1997; Lessa e Carmona-Ribeiro, 1996; Salay e Carmona-Ribeiro, 1998]. A concentração de lipídios na dispersão de vesículas utilizada neste experimento foi aquela em que nas isotermas de adsorção se obtinha a adsorção de bicamada sobre as partículas de sílica, mantendo-se a proporcionalidade em relação à área de $\mathrm{SiO}_{2}$ disponível para a adsorção, assim sendo, a concentração de lipídios utilizada neste experimento foi da 
ordem de micromolar, pois a lâmina de $\mathrm{SiO}_{2}$ utilizada possuía $2,754 \mathrm{~cm}^{2}$, enquanto que a área de sílica utilizadas nas isotermas era de $260 \mathrm{~cm}^{2}$.

O instrumento consiste em uma balança, na qual a lâmina é presa, e de um elevador sustentando a amostra líquida. A superfície líquida é lentamente movida ao longo da lâmina, e as forças exercidas sobre a lâmina são continuamente medidas em função da posição. A tensão superficial em qualquer local da fronteira de três fases causa uma força para baixo, enquanto o empuxo causa uma força para cima. A dispersão de vesículas é colocada em um béquer sobre a plataforma móvel. O sistema que mantém a lâmina é ajustado para alinhar a borda inferior da lâmina com a superfície líquida. $\mathrm{O}$ aparelho foi zerado com a lâmina sem contato com a superfície líquida. Imersão e retirada da lâmina ocorre pelo levantamento e abaixamento da plataforma, respectivamente.

O valor do ângulo de contato é calculado pela equação abaixo Johnson et al., 1977]:

$$
\cos \theta=\left(\frac{F+\rho g A h}{p \gamma}\right)
$$

onde,

$p=$ perímetro da lâmina $(\mathrm{cm})$

$\gamma=$ tensão superficial $(\mathrm{din} / \mathrm{cm})$

$F=$ força sobre a lâmina $(\mathrm{din})$

$\rho=$ densidade da água $(\mathrm{g} / \mathrm{mL})$

$g=$ aceleração da gravidade $=978,8 \mathrm{din} / \mathrm{g}$

$A$ =área da seção transversal da lâmina $\left(\mathrm{cm}^{2}\right)$

$h=$ profundidade de imersão.

A equação acima prevê uma relação linear entre $F$ e $h$, se $\theta$ é constante. Em uma dada velocidade constante e baixa. Para uma superfície lisa e homogênea com perímetro constante $p$, o ângulo de contato permanece constante ao longo do movimento [Johnson et al., 1977]. A força sobre a lâmina foi obtida da massa 
aparente pesada na balança, no instante de contato da superfície líquida com a base da lâmina, multiplicada pela aceleração da gravidade. Para determinação de $\theta$, a dependência da massa aparente com a profundidade (distância) foi obtida primeiro para imersão (avanço) e então para emersão (recesso). 


\section{III - Resultados e Discussão.}

III.1 - Deposição de fosfolipídios como bicamada sobre sílica hidrofílica.

Existe uma relação entre o mecanismo de adsorção molecular a uma superfície sólida e o tipo de isoterma de adsorção obtida [Giles et al., 1960]. Nessa seção será qualificada a adsorção para anfifilicos formadores de bicamadas sobre silica, tendo como meta dois objetivos principais: (1) determinação da condição experimental para obtenção de deposição de bicamada; (2) estabelecer a correlação entre o tipo de isoterma da adsorção e o possível mecanismo de deposição de bicamada sobre superfície hidrofilica, tendo uma dispersão de partículas de silica como modelo.

A figura III.1.1 mostra uma isoterma de adsorção típica para vesículas pequenas de PC sobre AEROSIL OX-50 em tampão Tris $10 \mathrm{mM}, \mathrm{pH} \mathrm{7,4,} \mathrm{a} 25^{\circ} \mathrm{C}$. A esta temperatura, a bicamada de PC está no estado líquido cristalino. 


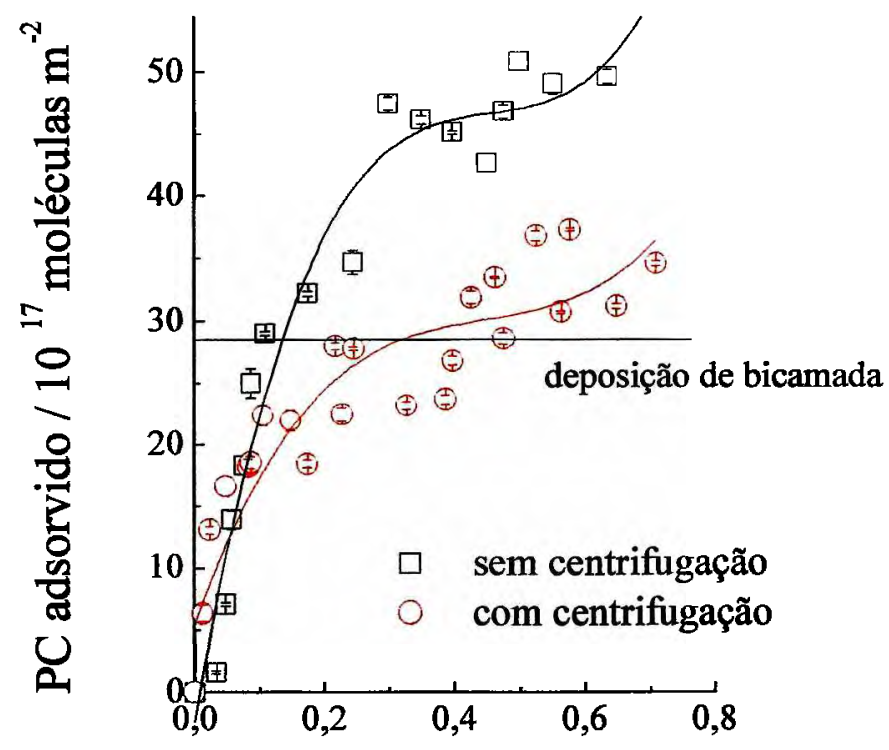

Concentração de PC no sobrenadante / mM

Figura III.1.1 - Isotermas de adsorção de PC a partir de vesículas pequenas sobre AEROSIL OX-50 (partícula coloidal de silica com $50 \mathrm{~nm}$ de diâmetro) em Tris 10 $\mathrm{mM} \mathrm{pH} 7,4 \mathrm{a} 25^{\circ} \mathrm{C}$. Vesículas pequenas foram centrifugadas a $14000 \mathrm{rpm}$ antes da interação com as partículas (O). A curva obtida quando esta centrifugação preliminar não é feita também é mostrada ( $\square$ ). A linha horizontal representa a quantidade esperada para deposição de uma bicamada de PC sobre cada partícula de sílica, assumindo uma área por molécula de PC igual a $0,7 \mathrm{~nm}^{2}$.

A adsorção é langmuiriana até $0,4 \mathrm{mM}$ de PC no sobrenadante. Essa forma é indicativa de orientação vertical do adsorbato com atração intermolecular particularmente forte [Giles et al., 1960]; isto é, o que é esperado para deposição de bicamada inteira. $\mathrm{Na}$ adsorção limite, $27 \times 10^{17}$ moléculas de PC estão adsorvidas por metro quadrado de silica, o que representa que cada molécula de PC está ocupando $0,37 \mathrm{~nm}^{2}$. Este valor é cerca de metade da área por monômero de PC em monocamada na interface ar/água, que é $0,70 \mathrm{~nm}^{2}$ sugerindo deposição de bicamada sobre a sillica hidrofilica. A centrifugação preliminat da dispersão de silica antes da interação com sílica é importante para prevenir valores superestimados da adsorção de PC. Possivelmente, alguns lipossomos multilamelares de PC presentes na preparação de vesículas unilamelares pequenas (SUV) são separados juntamente com as partículas de sílica durante a centrifugação e a concentração de PC 
determinada no sobrenadante será menor que a real. Essa superestimativa da quantidade adsorvida por ser facilmente eliminada pela centrifugação da dispersão de vesículas imediatamente antes da interação com a silica. É interessante como a silica hidroflica origina a deposição de bicamada de PC em contraste com as bolinhas de vidro de bário titanato, que são mais hidrofóbicas e induzem o recobrimento com uma monocamada, expondo os grupos polares para a fase aquosa Jackson et al., 1987; Kalb et al 1992]. De fato, interação entre vesículas pequenas de $\mathrm{PC}$ e microesferas de poliestireno amidina também origina deposição de monocamada de PC sobre a superfície hidrofóbica de látex [Carmona-Ribeiro e Herrington, 1993]. Esses resultados podem ser compreendidos como um conjunto, assumindo um o papel decisivo para a natureza hidrofóbica/hidrofilica da superfície orientando a deposição de fosfolipídio neutro: deposição de monocamada em superfície hidrofóbica e deposição de bicamada em superfície hidrofilica. Uma terceira possibilidade pode ser a formação de ilhas de agregados moleculares sobre a superfície.

A figura III.1.2 mostra isotermas de adsorção típicas para adsorção de vesículas pequenas de PC sobre AEROSIL OX-50 em água pura ou em tampão 10 $\mathrm{mM}$ em três valores de $\mathrm{pH}$ e $25^{\circ} \mathrm{C}$. 


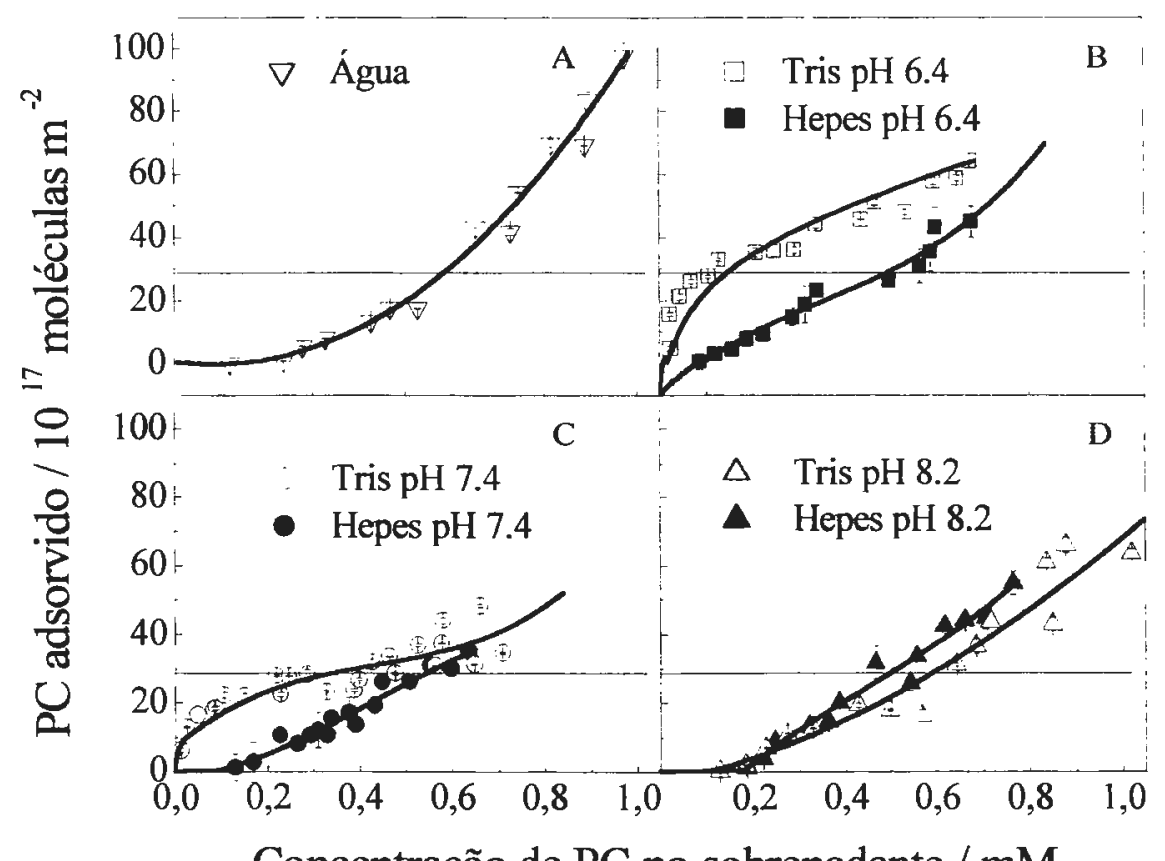

Concentração de PC no sobrenadante / $\mathrm{mM}$

Figura III.1.2 - Isotermas de adsorção de PC a partir de vesículas pequenas, sobre silica hidrofilica $\left(50 \mathrm{~nm}\right.$ de diâmetro) em água a $25^{\circ} \mathrm{C}(\mathrm{A})$ ou $10 \mathrm{mM}$ de Tris ou HEPES em pH 6,4 (B), 7,4 (C) ou 8,2 (D). Área superficial total em $1 \mathrm{~mL}$ de mistura de interação foi fixada em $0,026 \mathrm{~m}^{2}$. A linha horizontal representa a quantidade adsorvida esperada para deposição de uma única bicamada de PC sobre as partículas de sílica, assumindo uma área por molécula igual a $0,7 \mathrm{~nm}^{2}$.

Adsorção de PC a partir de vesículas pequenas em água ou em HEPES é representada por isotermas de adsorção de muito baixa afinidade em todos os $\mathrm{pHs}$ testados. Esta baixa afinidade não parece chegar em um valor de platô indicativo de deposição de bicamada. Por outro lado, em presença de $10 \mathrm{mM}$ de Tris em $\mathrm{pH}$ $\leq 7,4$ (Figura III.1.2 B e C), a afinidade pela superfície de sílica é maior e a adsorção é langmuiriana até $0,4 \mathrm{mM}$ de PC no sobrenadante. A figura III.1.2 também descreve a dependência de adsorção de bicamada de PC com a natureza do tampão. Para Tris, que possui grupos amino protonados $(\mathrm{pH} \leq 7,4)$, a afinidade entre vesículas de PC e superfície de silica aumenta e se obtém deposição de bicamada (Figura III.1.2 B e C). Isso se torna compreensível assumindo adsorção de Tris positivamente carregado sobre a superfície de sílica. A possibilidade de formação 
de pontes de hidrogênio entre o grupo $-\mathrm{P}=\mathrm{O}$ das moléculas de $\mathrm{PC}$ e os grupos $\mathrm{OH}$ do Tris adsorvido deveria de fato aumentar a afinidade pela superfície de sílica. Aumentando o $\mathrm{pH}$ para 8,2, e sabendo-se que o pKa do Tris é $\mathrm{pH} 8,0$, mais da metade das moléculas de Tris perderam sua carga positiva, assim a adsorção de Tris sobre sillica diminui, com isso diminuindo a adsorção de PC. Também é interessante observar que HEPES não causa efeito similar sobre adsorção de sílica (figura III.1.2). Isso também é explicado pela estrutura química do HEPES. Não é possível para o HEPES ser atraído eletrostaticamente pela silica, o HEPES possui uma carga negativa no grupo sulfônico, assim HEPES tem caráter zwiteriônico ou carregado negativamente nos $\mathrm{pHs}$ testados. Isso explica porque $\mathrm{PC}$ não tem a afinidade aumentada na presença de HEPES (figura III.1.2): HEPES não é capaz de adsorver sobre a sillica.

A figura III.1.3 mostra as estruturas químicas dos tampões Tris e HEPES.

Tris: 2-(hidroximetil)-2-amino-1,3-propanodiol

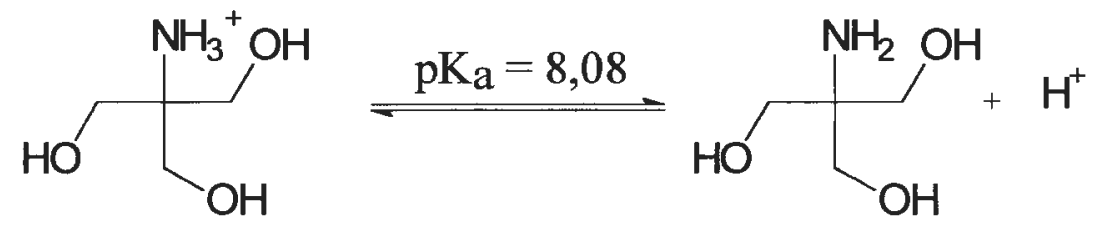

HEPES: ácido 4-(2-hidroxietil)-1-piperazinoetanosulfônico

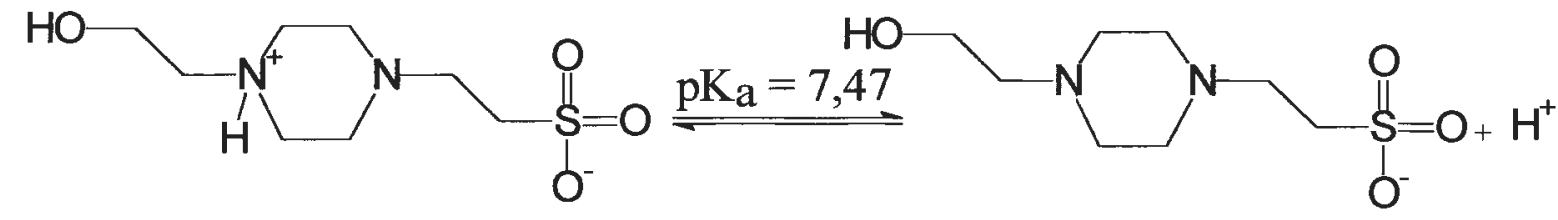

Figura III.1.3 - Estruturas químicas dos tampões utilizados Tris e HEPES.

Aumentando o pH de 6,4 até 8,2, há um aumento da carga superficial sobre a silica [Tadros e Lyklema, 1968; Milonjić, 1987]. Como PC é zwiteriônico, não é 
esperado um efeito da carga superficial de sílica, e de fato, nenhum efeito foi observado para PC em água e HEPES em três diferentes pHs. O efeito de $\mathrm{pH}$ observado para adsorção de PC utilizando Tris como tampão foi mostrado como sendo associado com a carga positiva do tampão a $\mathrm{pH} \leq 7,4$, sua conseqüente adsorção sobre a sílica e um aumento da adsorção de PC devido à pontes de hidrogênio entre o tampão adsorvido e PC.

A figura III.1.4 mostra a linearização da isoterma de adsorção de PC a partir de vesículas pequenas sobre partículas de sillica hidrofílica em tampão Tris $10 \mathrm{mM}$, $\mathrm{pH} 7,4$.

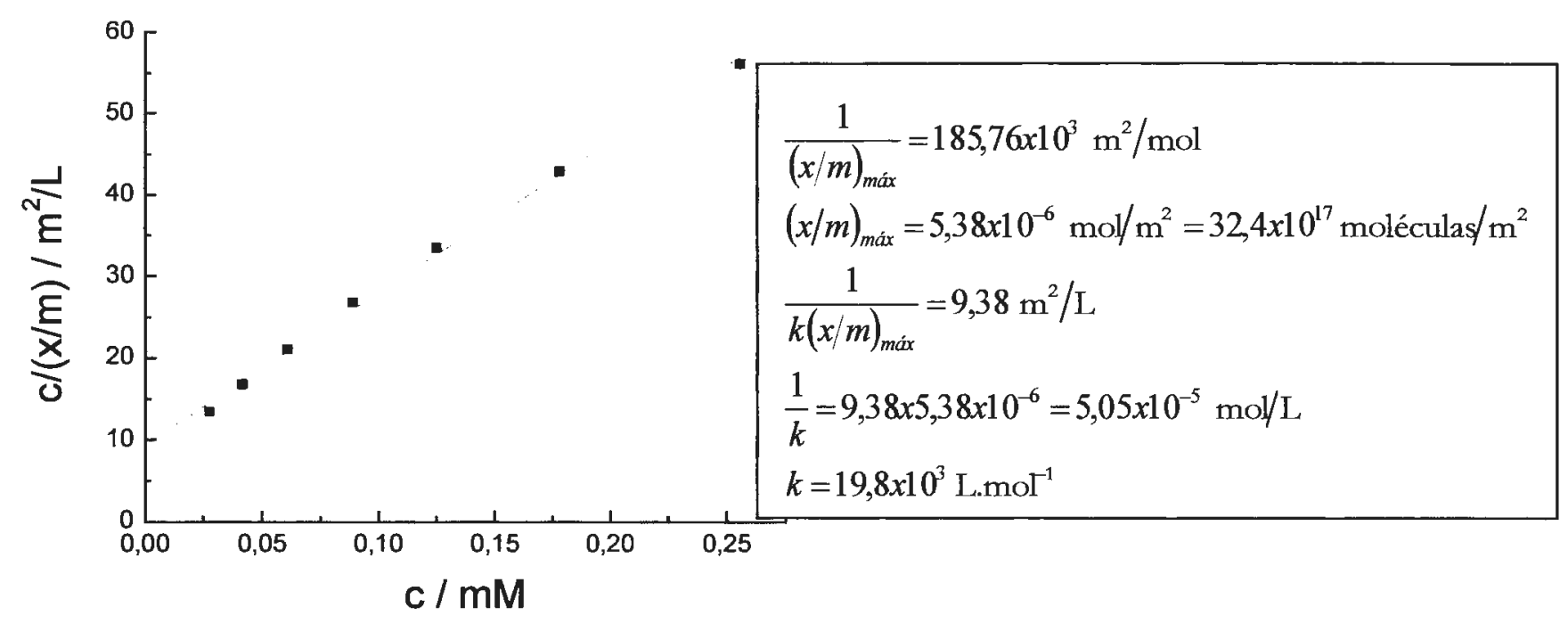

Figura III.1.4 - Linearização da isoterma de adsorção de PC a partir de vesículas pequenas sobre partículas de sílica hidrofilica em tampão Tris $10 \mathrm{mM}, \mathrm{pH}$ 7,4.

Adsorção de DPPC a partir de vesículas pequenas de DPPC sobre sílica em tampão Tris $10 \mathrm{mM} \mathrm{pH} \mathrm{7,4} \mathrm{depende} \mathrm{do} \mathrm{estado} \mathrm{físico} \mathrm{da} \mathrm{bicamada} \mathrm{de} \mathrm{DPPC} \mathrm{como}$ mostrado na figura III.1.5. 


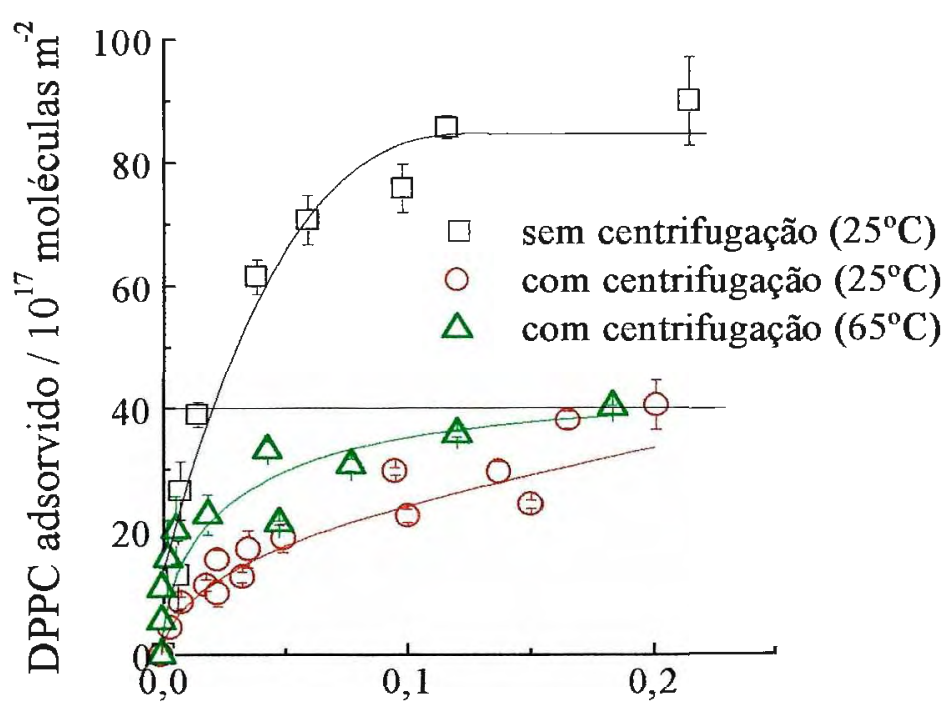

Concentração de DPPC no sobrenadante / $\mathrm{mM}$

Figura III.1.5 - Isotermas de adsorção de DPPC a partir de vesículas pequenas de DPPC sobre partículas de $\mathrm{SiO}_{2}$ em tampão Tris $\mathrm{pH} 7,4,25^{\circ} \mathrm{C}(\square)$ vesículas pequenas de DPPC foram centrifugadas a $14000 \mathrm{rpm}$ antes interação com silica $(O$, $\triangle$ ). A curva obtida quando esta centrifugação não é executada também é mostrada (). Quando vesículas pequenas de DPPC e silica interagem a $65^{\circ} \mathrm{C}$ por 1 hora $(\triangle)$, a afinidade de DPPC pela silica aumenta e recobrimento por bicamada é atingido em concentrações de DPPC no sobrenadante menores em comparação à situação a $25^{\circ} \mathrm{C}(\mathrm{O})$.A linha horizontal representa a quantidade de DPPC requerida para adsorção de bicamada, assumindo que uma molécula de DPPC ocupa $0,5 \mathrm{~nm}^{2}$ sobre a silica.

A ausência de centrifugação prévia resulta em superestimativa da quantidade adsorvida medida. A $65^{\circ} \mathrm{C}$, as vesículas de DPPC estão no estado líquido-cristalino, a afinidade da bicamada de DPPC pela silica é significativamente maior do que a obtida a $25^{\circ} \mathrm{C}$ para vesículas no estado gel. Vesículas no estado gel não fundem facilmente sobre a silica para gerar deposição de bicamada como as vesículas em estado mais fluido. Entretanto, adsorção limite para ambas curvas parece ocorrer a $40 \times 10^{17}$ moléculas adsorvidas por metro quadrado de sílica. Esse valor é equivalente a uma área por monômero de $0,25 \mathrm{~nm}^{2}$ por molécula de silica, um valor compatível com a deposição de bicamada na adsorção máxima. Para dispersão de 
vesículas previamente centrifugadas, interação por 1 hora a $65^{\circ} \mathrm{C}$ pode ter levado a deposição de bicamada. Interação entre vesículas pequenas unilamelares de DPPC e sillica durante 24 horas a $25^{\circ} \mathrm{C}$, embora ocorra menos rapidamente e com menor afinidade, pode também gerar deposição de bicamada de DPPC. O tempo de adsorção para vesículas sonicadas de DPPC sobre vidro de bário titanato foi descrito, com adsorçăo de equilíbrio ocorrendo em cerca de 1,5 h [Jackson et al., 1986].

Isotermas de adsorção de vesículas pequenas de DPPC sobre sillica em água ou em 10 mM de tampão em três valores de $\mathrm{pH}$ são mostradas na figura III.1.6.

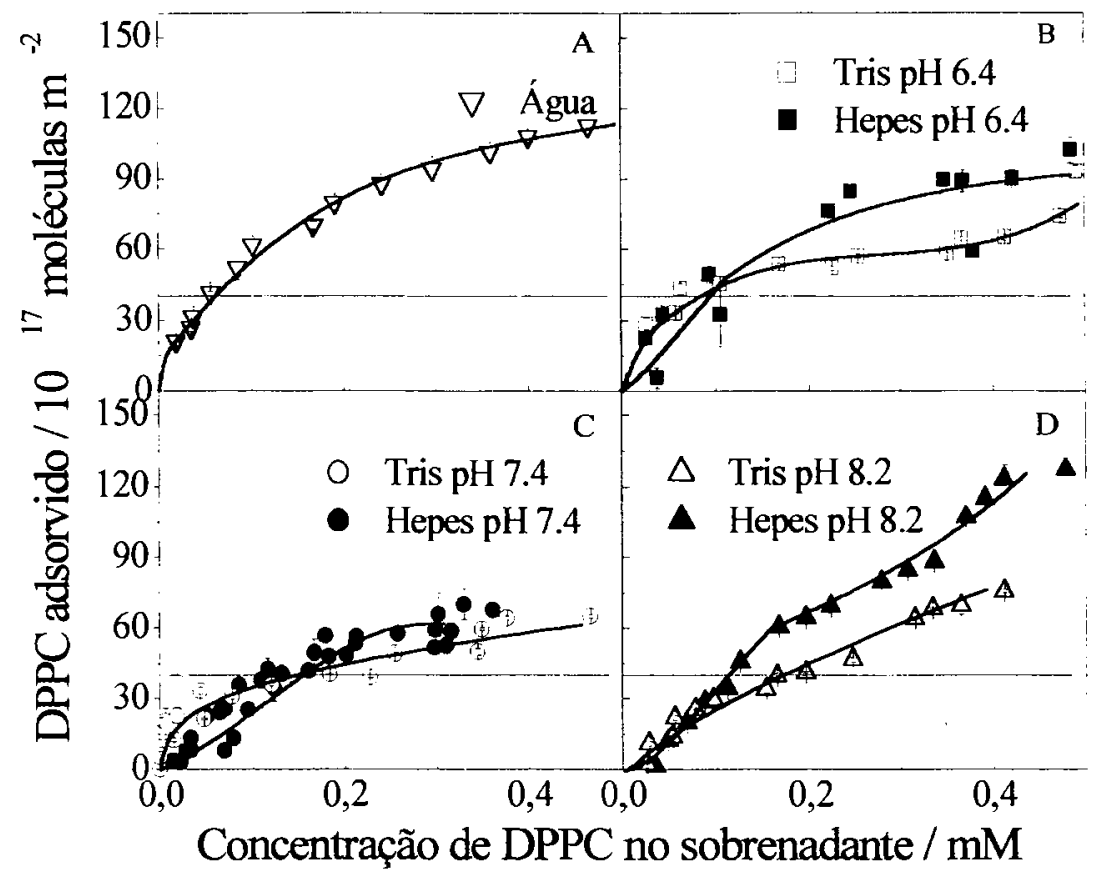

Figura III.1.6 - Isotermas de adsorção de DPPC a partir de vesículas pequenas de DPPC sobre partículas de silica em água a $65^{\circ} \mathrm{C}(\mathrm{A})$ ou $10 \mathrm{mM}$ de Tris ou HEPES a pH 6,4 (B), 7,4 (C), ou 8,2 (D). A área de $\mathrm{SiO}_{2}$ foi fixada em $0,026 \mathrm{~m}^{2}$ por $\mathrm{mL}$. A linha horizontal representa a adsorção esperada para deposição de uma bicamada de DPPC sobre partículas de sílica, assumindo uma área por molécula de DPPC igual a $0,5 \mathrm{~nm}^{2}$.

Neste caso, a afinidade entre DPPC e sílica em água é maior que afinidade entre PC e silica (figura III.1.6). A pH $\leq 7,4$, a adsorção em presença de Tris 
apresenta afinidades ligeiramente maiores pela superfície de silica do que aquelas apresentadas na presença de HEPES (figura III.1.6 B e C). Deposição de bicamada descrita a partir de dois platôs bem definidos na figura III.1.6 C parecem ter uagar

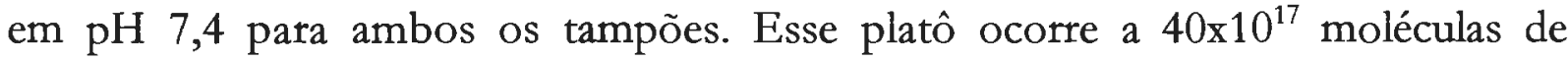
DPPC adsorvidas por metro quadrado de silica, o que significa a deposição de uma bicamada.

Sílica adsorve vários cátions com alta afinidade [Tadros e Lyklema, 1968]. Entre esses estão os cátions orgânicos como o DODAB e cloreto de tetraetilamônio (TEA) [Tadros e Lyklema, 1968; Milonjić, 1987]. O tampão Tris, também é um sal orgânico, e não deve ser uma exceção, principalmente em $\mathrm{pH} \leq 8,0, \mathrm{pH}$ onde Tris está $50 \%$ dissociado e conseqüentemente, $50 \%$ das moléculas de Tris são cátions orgânicos positivamente carregados. $\mathrm{O}$ efeito de tampão sobre adsorção de fosfolipídio é claramente visto pela substituição de 'Tris por HEPES em três valores de $\mathrm{pH}$. Afinidade de PC pela superfície sólida é mais alta em Tris do que em HEPES. Adsorção de Tris sobre sílica leva a um aumento na densidade superficial de hidroxilas para formação de ponte de hidrogênio com $-\mathrm{P}=\mathrm{O}$ do fosfolipídio. Como HEPES não é um cátion orgânico, em sua presença, a afinidade de fosfolipídio pela silica mantém-se baixa.

A figura III.1.7 mostra a linearização da isoterma de adsorção de DPPC a partir de vesículas pequenas sobre partículas de sílica hidrofilica, em tampão Tris 10 $\mathrm{mM}, \mathrm{pH} 7,4, \mathrm{a} 65^{\circ} \mathrm{C}$. 


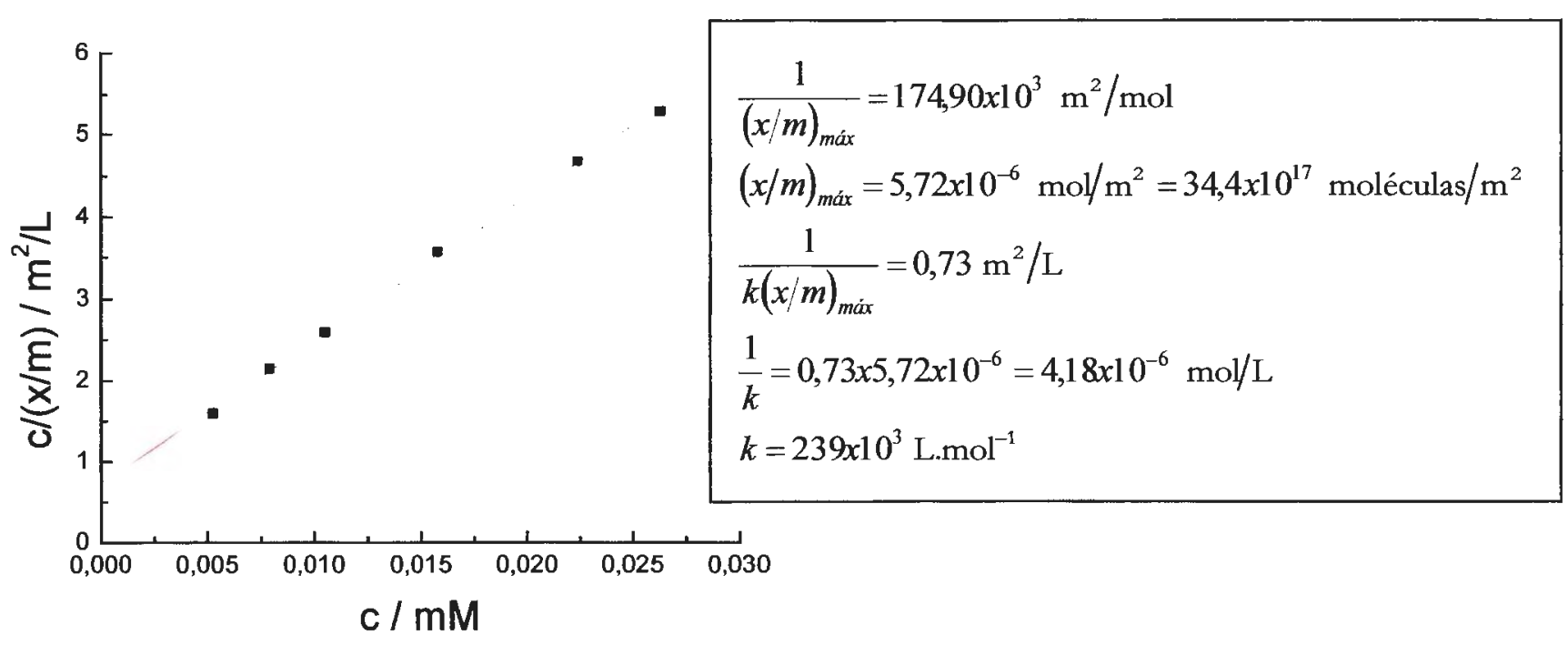

Figura III.1.7 - Linearização da isoterma de adsorção de DPPC a partir de vesículas pequenas sobre partículas de sílica hidrofílica, em tampão Tris $10 \mathrm{mM}, \mathrm{pH}$ 7,4 , a $65^{\circ} \mathrm{C}$, a dispersão de vesículas foi previamente centrifugada.

\section{III.2 - Deposição de anfifílicos sintéticos catiônicos e aniônicos} formadores de bicamadas sobre sílica

A adsorção de DHP a partir de vesículas pequenas sobre silica hidrofilica é representada por isotermas do tipo S (figura III.2.1). 


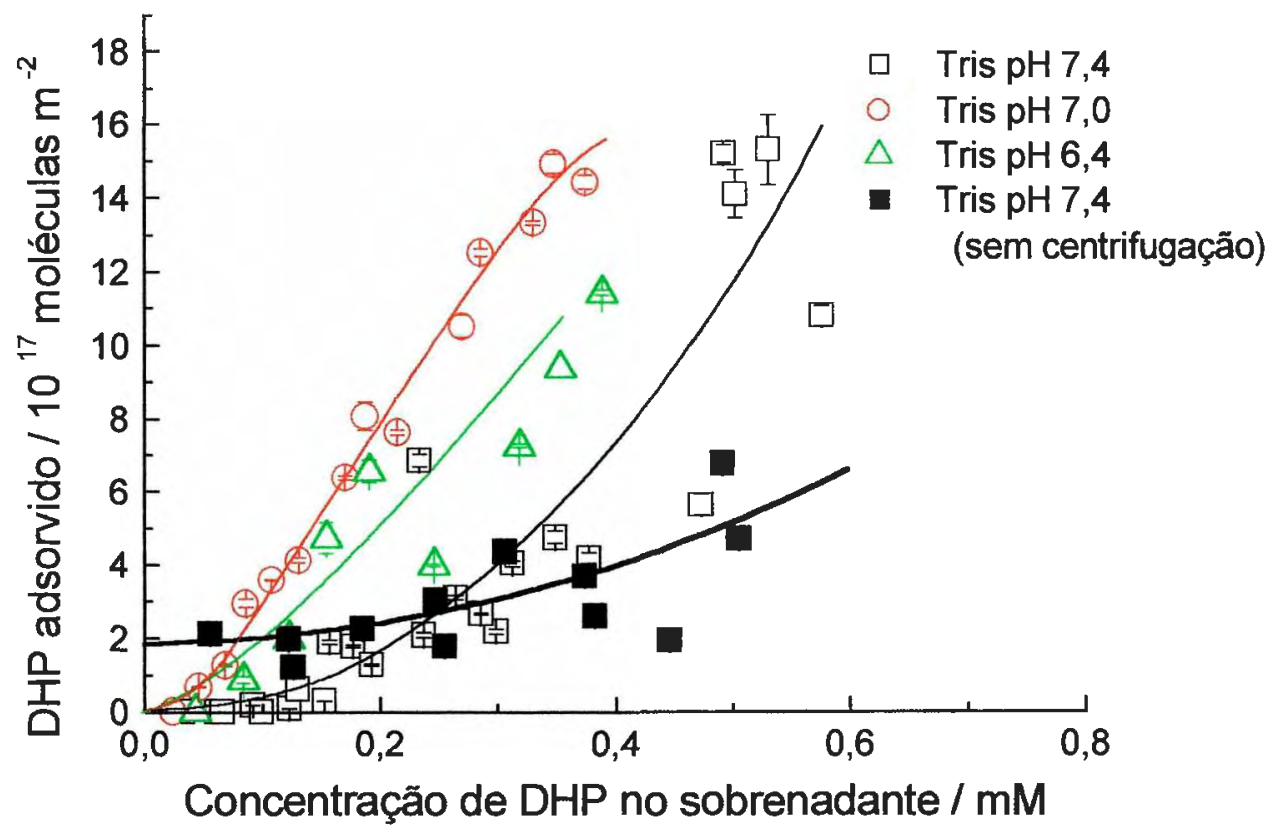

Figura III.2.1 - Isotermas de adsorção DHP a partir de vesículas pequenas sobre partículas de silica, em Tris $5 \mathrm{mM}$, a $25^{\circ} \mathrm{C}$ e pH 7,4 ( $\left.\square, \square\right), 7,0(\bigcirc)$, e $6,4(\triangle)$. Não foi observado efeito de centrifugação preliminar da dispersão de vesículas. No entanto, as dispersões de vesículas foram sistematicamente centrifugadas antes da obtenção do efeito de $\mathrm{pH}$ sobre a adsorção de DHP. Note que pequena quantidade adsorvida for obtida em todos os casos.

Quanto mais DHP é adsorvido, mais fácil é para quantidades adicionais de DHP ser fixada. Na prática, a curva $\mathrm{S}$ usualmente aparece quando três condições são preenchidas: (1) o adsorbato é monofuncional, isto é, a molécula a ser adsorvida tem um resíduo hidrofóbico grande $(\mathrm{C}>5)$; (2) o adsorbato tem moderada atração intermolecular, causando um empacotamento vertical na camada adsorvida; e (3) o adsorbato encontra forte competição, pelos sítios do substrato, a partir de moléculas do solvente e outras espécies adsorvidas [Giles et al, 1960]. Na verdade a superfície de silica contém moléculas de água que estão ligadas à superfície por pontes de hidrogênio com os grupos silanóis, assim a cabeça de fosfato de DHP encontra forte competição com as moléculas de água para se ligar via ponte de hidrogênio à superfície de sílica. Além disso, a pH 7,4 e 0,01 $\mathrm{M}$ de sal a superfície de silica está negativamente carregada [Tadros e Lyklema, 1968; 
Milonjić, 1987]. A pH 7,4, a densidade de carga sobre a silica é $-11 \mu \mathrm{C} / \mathrm{cm}^{2}$ [Tadros, Lyklema, 1968]. A repulsão eletrostática afasta as moléculas aniônicas de DHP da superfície da silica. Conseqüentemente, a adsorção de DHP mantém-se bem abaixo das obtidas para fosfolipídios em faixas de concentrações equivalentes. DHP não deposita como bicamada contínua sobre sílica, mesmo para os menores valores de $\mathrm{pH}$. O pKa do fosfato em vesículas de DHP é estimado como 6,5 - 7,0 [Carmona-Ribeiro e Hix, 1991]. Assim, diminuindo a carga da superfície da vesícula de DHP por diminuição do $\mathrm{pH}$ de 7,4 a 6,4 ou 7,0 consistentemente, há um pequeno, mas significativo aumento na adsorção.

Em contraste, a afinidade de DODAB, um anfifilico catiônico, por silica é tão alta que adsorção de bicamada parece ser sempre acompanhada por adesão de vesícula às partículas de silica (figuras III.2.2 e III.2.3).

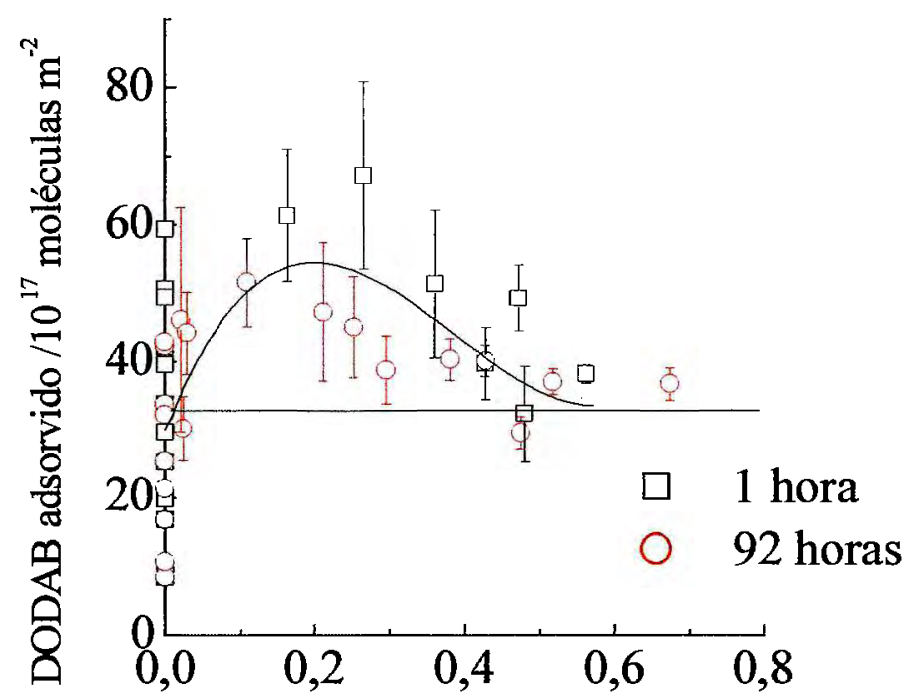

Concentração de DODAB no sobrenadante / $\mathrm{mM}$

Figura III.2.2 - Isotermas de adsorção de DODAB a partir de vesículas pequenas sobre AEROSIL OX-50 em Tris $10 \mathrm{mM}, \mathrm{pH}$ 8,2. Centrifugação preliminar das dispersões de vesículas $(14000 \mathrm{rpm}, 1 \mathrm{~h})$ for executado para ambas isotermas. Interação entre vesículas e partículas foi feita durante 1 hora a $42^{\circ} \mathrm{C}$, i.e, acima da temperatura de transição de fase para bicamadas de DODAB. As vesículas utilizadas foram preparadas com $1 \mathrm{~h}(\square)$ ou 92 horas $(O)$ de antecedência. A linha horizontal representa a quantidade requerida para deposição de uma bicamada de DODAB por partícula de sílica, assumindo $0,6 \mathrm{~nm}^{2}$ como área por molécula de DODAB. 


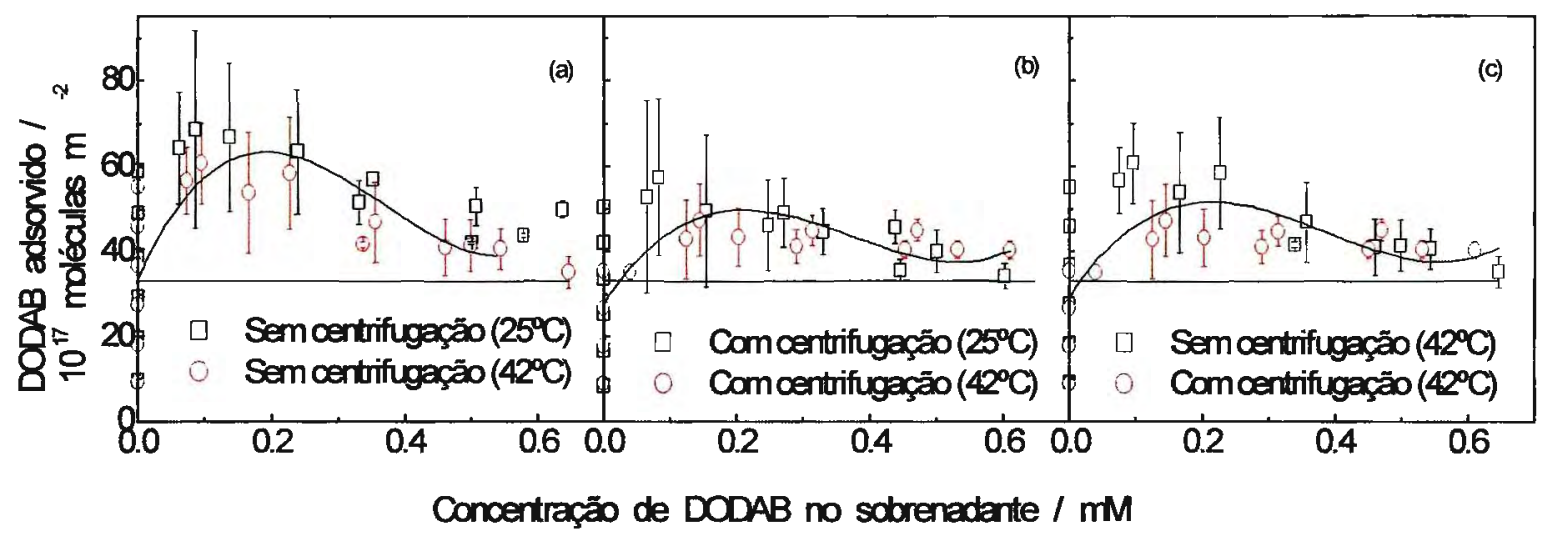

Figura III.2.3 - Isotermas de adsorção de DODAB a partir de vesículas pequenas sobre AEROSIL OX-50 em Tris $10 \mathrm{mM}, \mathrm{pH} 7,4$ a duas temperaturas diferentes de interação e com (b) ou sem (a) centrifugação preliminar. Partículas e vesículas interagiram por $1 \mathrm{~h} \mathrm{a} 25$ ou $42^{\circ} \mathrm{C}$. Não foi observado efeito de centrifugação ou temperatura de interação dentro dos limites de erro experimental.

Uma observação comum em todas as isotermas é que elas são do tipo H (alta afinidade). Em getal este tipo de isoterma é obtido quando o adsorbato tem tão alta afinidade que, em soluções diluídas, é completamente adsorvido, ou pelo menos quantidades remanescentes na solução não são mensuráveis. A parte inicial da isoterma é vertical. As espécies adsorvidas são, freqüentemente, unidades grandes, isto é, micelas iônicas ou moléculas poliméricas [Giles et al, 1960]. Algumas vezes as espécies adsorvidas são íons simples que trocam com outros de menor afinidade pela supetfície [Giles et al, 1960]. Essa alta afinidade entre DODAB e sillica é compativel com a formação de par iônico entre os grupos silanóis dissociados da sílica e os grupos amônio quaternário do DODAB. Esta alta afinidade possivelmente gera um agregado de vesículas pequenas de DODAB sobre partículas de silica, pois os níveis de adsorção de DODAB em baixas concentrações no sobrenadante são maiores que o esperado para recobrimento com uma bicamada. Contudo, com o aumento da concentração de DODAB, a quantidade adsorvida diminui, tendendo ao que é esperado para recobrimento com bicamada. 
Em suma, isotermas de adsorção para DODAB sobre sílica pertencem ao tipo $\mathrm{H}$ com um máximo $(\mathrm{Hmx})$. Em geral, esse tipo de isoterma resulta da associação do adsorbato em solução [Giles et al., 1960], isto é, aumentando a concentração de $\mathrm{DODAB}$, a interação vesícula/vesícula em solução aumenta mais rapidamente que a atração pelo substrato (sílica). $\mathrm{Na}$ verdade, vesículas de DODAB sonicadas interagem entre si devido à sua preferência por menor curvatura, presença de fragmentos de bicamada, tendência a formar lipossomos multilamelares, tendência a fundir, etc [Carmona-Ribeiro, 1992]. Conseqüentemente, vesículas que permanecem em solução agem como seqüestradoras do excesso de vesículas na superfície de sílica e assim a deposição de bicamada ocorre somente em altas concentrações de DODAB no sobrenadante.

O efeito da idade das vesículas sobre a adsorção foi determinado a $\mathrm{pH} 8,2$ por 1 hora de interação a $42^{\circ} \mathrm{C}$. Vesículas com duas idades diferentes foram usadas (1 e 92 horas) (figura III.2.2). Centrifugação preliminar foi feita antes de misturar vesículas e partículas. Dentro do erro experimental não há efeito da idade da vesícula sobre a adsorção máxima ou sobre a deposição de bicamada (figura III.2.2). Também, centrifugação preliminar ou estado físico da bicamada não parece de importância na determinação da adsorção de $\mathrm{DODAB}$ sobre sillica (figura III.2.3). Isso é consistente com um mecanismo de adsórção para DODAB envolvendo a formação de par iônico do tetralquilamônio e o silanol deprotonado, uma interação de superfície que não deve depender da fluidez da bicamada e deve ser efetiva no surgimento da ruptura da bicamada em seu contato com a partícula de silica, a qual é essencial para o recobrimento com uma bicamada. Em geral, a atração eletrostática entre partículas de sílica e vesículas catiônicas efetivamente gera a deposição de bicamada.

A figura III.2.3 mostra o efeito da natureza do tampão e $\mathrm{pH}$ sobre a adsorção de $\mathrm{DODAB}$ em partículas de silica hidrofilica. 


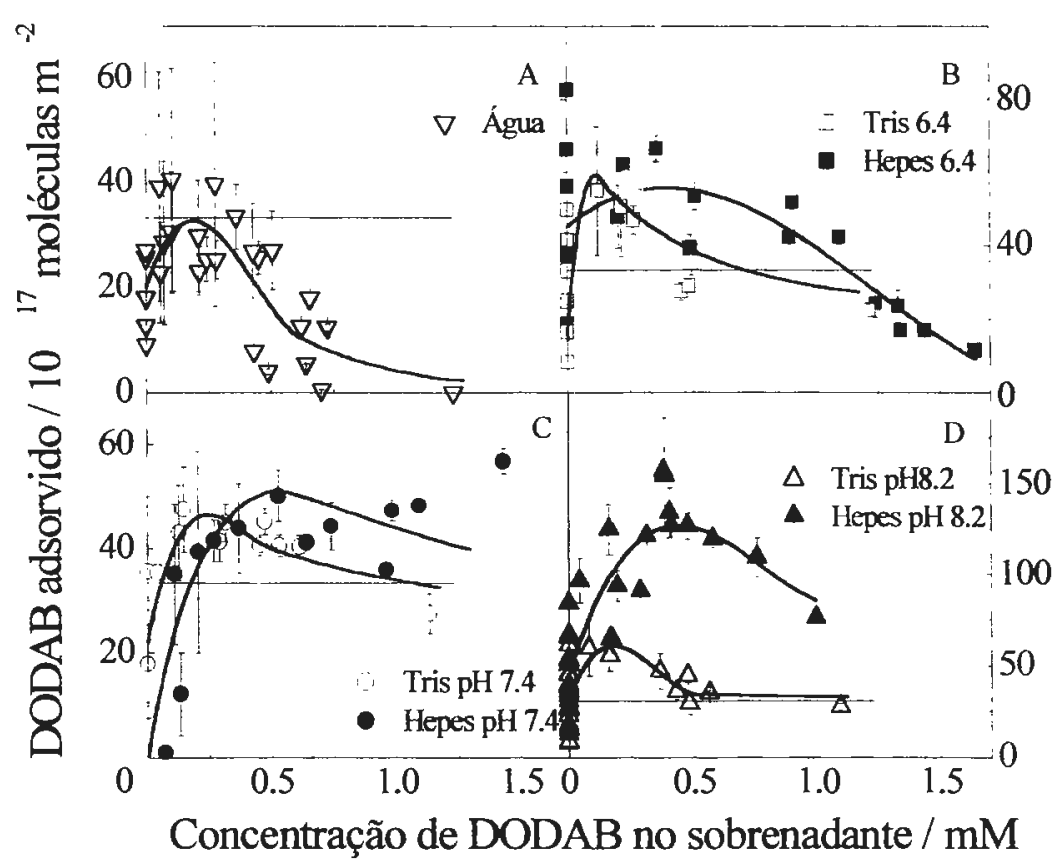

Figura III.2.4 - Isotermas de adsorção de DODAB a partir de vesículas pequenas sobre sillica hidrofilica, em água a $42^{\circ} \mathrm{C}$ (A) ou $10 \mathrm{mM}$ Tris ou HEPES a pH 6,4 (B), 7,4 (C) ou 8,2 (D). A área de silica foi fixada em $0,026 \mathrm{~m}^{2}$ por $\mathrm{mL}$. A linha horizontal representa a adsorção esperada para deposição de bicamada sobre partículas de silica, assumindo uma área por molécula de DODAB igual a $0,6 \mathrm{~nm}^{2}$.

$\mathrm{Na}$ figura III.2.4, aumentando a densidade de carga da superfície, decorrente do aumento do $\mathrm{pH}$ de 6,4 a 8,2, a quantidade máxima de DODAB adsorvida aumenta. Também, em HEPES a adsorção parece ser sistematicamente maior do que em Tris (figura III.2.4 B, C e D). Isso pode ser explicado devido à ausência de adsorção específica de HEPES sobre silica gerando uma maior densidade de carga sobre a superfície. Em água, quando a densidade de carga sobre a superfície da silica é a menor possível [Tadros e Lyklema, 1968], há uma tendência de desorção da bicamada (figura III.2.4 A). A afinidade de DODAB pela sílica mantém-se alta, mas a adsorção monotonicamente decresce a zero em função da concentração de DODAB no sobrenadante. Adsorção de bicamada de DODAB, atingida em concentrações baixas de DODAB no sobrenadante e devida à formação de pares iônicos, as vesículas adsorvidas podem ser facilmente removidas por interação intervesículas. Assim na menor densidade de carga de silica em água $\left(-1 \mu \mathrm{C} / \mathrm{cm}^{2}\right)$ 
[Tadros e Lyklema, 1968], apesar da ocorrência de deposição de bicamada de DODAB a baixas concentrações de DODAB no sobrenadante, o recobrimento não é estável.

$$
\text { Cátions orgânicos monovalentes como tetraetilamônio (TEA) }
$$
substancialmente aumentam a densidade superficial de súlica em comparação com a densidade obtida na presença de sais inorgânicos monovalentes [Tadros e Lyklema, 1968] (Tabela III.2.1).

Tabela III.2.1 - Densidade superficial de carga sobre silica e vesículas em função do $\mathrm{pH}$ em $0,01 \mathrm{M}$ de $\mathrm{KCl}, \mathrm{NaCl}^{\mathbf{a}}$, ou cloreto de tetraetilamônio (TEA) .

\begin{tabular}{|c|c|c|c|c|c|}
\hline \multirow[b]{3}{*}{$\mathrm{pH}$} & \multicolumn{5}{|c|}{ Densidade superficial de carga $\left(\mu \mathrm{C} / \mathrm{cm}^{2}\right)$} \\
\hline & \multicolumn{3}{|c|}{ Sillica } & \multicolumn{2}{|c|}{ Vesículas } \\
\hline & $0,01 \mathrm{M} \mathrm{KCl}$ & TEA & $0,001 \mathrm{M} \mathrm{KCl}$ & DODAB & DHF \\
\hline 6,0 & -1 & -10 & & $2^{c}$ & $-2^{c}$ \\
\hline 6,4 & -3 & -10 & -1 & & \\
\hline 7,4 & -8 & -11 & & & \\
\hline 8,2 & -18 & -14 & & & \\
\hline
\end{tabular}

Tris também é um cátion orgânico em $\mathrm{pH} \leq 8,0$ e é comparável ao TEA. A mudança do $\mathrm{pH}$ de 6,0 a 7,4 não causa substancial alteração na densidade superficial de carga sobre a silica em presença de $10 \mathrm{mM}$ de TEA (tabela III.2.1). Assim, assumindo que a densidade superficial de carga da sílica em Tris $10 \mathrm{mM}$ segue o mesmo padrão como em TEA em função do $\mathrm{pH}$, nenhum efeito de $\mathrm{pH}$ sobre a adsorção de DODAB entre pH 6,0 e 7,4 é esperado. De fato, na presença de Tris como tampão, adsorção de DODAB sobre súlica não parece ser muito afetada pelo $\mathrm{pH}$ na faixa de $\mathrm{pH}$ de 6,4 a 7,4. Em baixas concentrações de DODAB no sobrenadante, considerando as grandes barras de erro na figura III.2.4, que são esperadas devido a sensibilidade do método (10 $\mu \mathrm{M}$ DODAB), uma significante diferença nas isotermas de adsorção de DODAB foi obtida em HEPES a pH 7,4 e 
8,2 , consistente com -10 e $-14 \mu \mathrm{C} / \mathrm{cm}^{2}$ para densidades superficiais de carga sobre silica, respectivamente. Porém, comparando a adsorção de DODAB em dois extremos de densidade de carga com -1 (água pura, $\mathrm{pH}$ 6,4) e $-11 \mu \mathrm{C} / \mathrm{cm}^{2}$ (Tris 10 $\mathrm{mM} \mathrm{pH}$ 6,4). Conclui-se que uma certa densidade de carga, maior que $-1 \mu \mathrm{C} / \mathrm{cm}^{2}$ é requerida para estabilizar a bicamada catiônica adsorvida ao suporte de sílica.

A figura III.2.5 mostra como varia a adsorção de DODAB sobre sílica hidrofílica em função de densidade superficial da sílica em quatro concentrações de DODAB no sobrenadante.

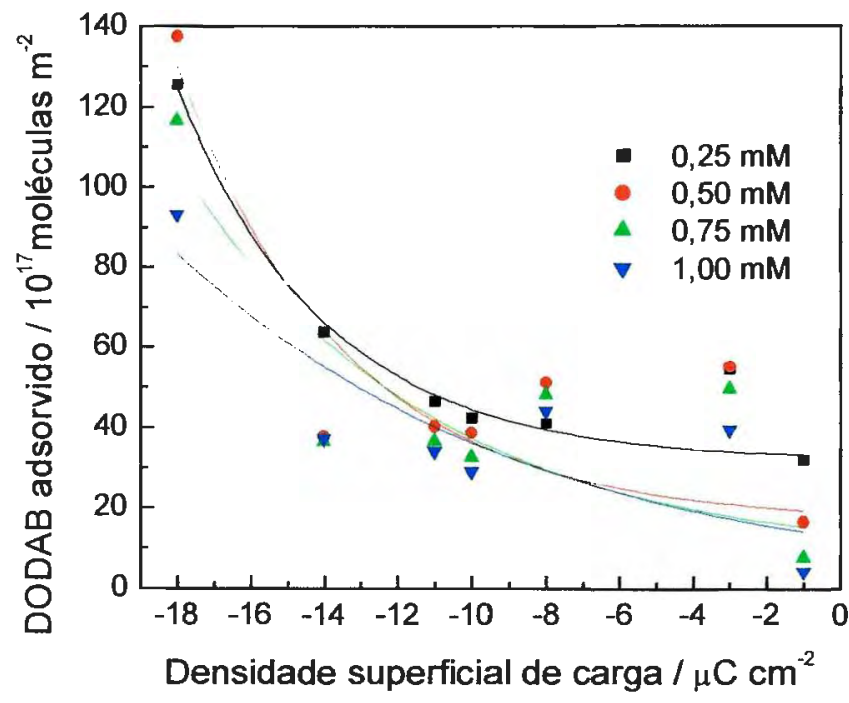

Figura III.2.5 - Adsorção de DODAB em sílica hidrofilica em função da densidade superficial de carga da silica em quatro concentrações de DODAB no sobrenadante: $0,25 \mathrm{mM}(\boldsymbol{\bullet}), 0,50 \mathrm{mM}(\bullet), 0,75 \mathrm{mM}(\boldsymbol{\Delta})$ e $1,00 \mathrm{mM}(\boldsymbol{\nabla})$. As densidades superficiais de carga foram obtidas da tabela III.2.1.

Podemos perceber que a adsorção de DODAB sobre silica hidrofílica aumenta exponencialmente com a densidade superficial de carga negativa sobre a silica. Esta dependência indica a adsorção é dirigida via formação de pares iônicos entre a o grupo amônio quaternário da cabeça polar do DODAB e os grupos silanóis dissociados da sílica. 
A figura III.2.6 mostra a linearização da isoterma adsorção de DODAB sobre partículas de sílica hidrofilica em tampão Tris $10 \mathrm{mM}, \mathrm{pH}$ 7,4. A dispersão de vesículas foi previamente centrifugada e a interação ocorreu por 1 hora a $42{ }^{\circ} \mathrm{C}$.

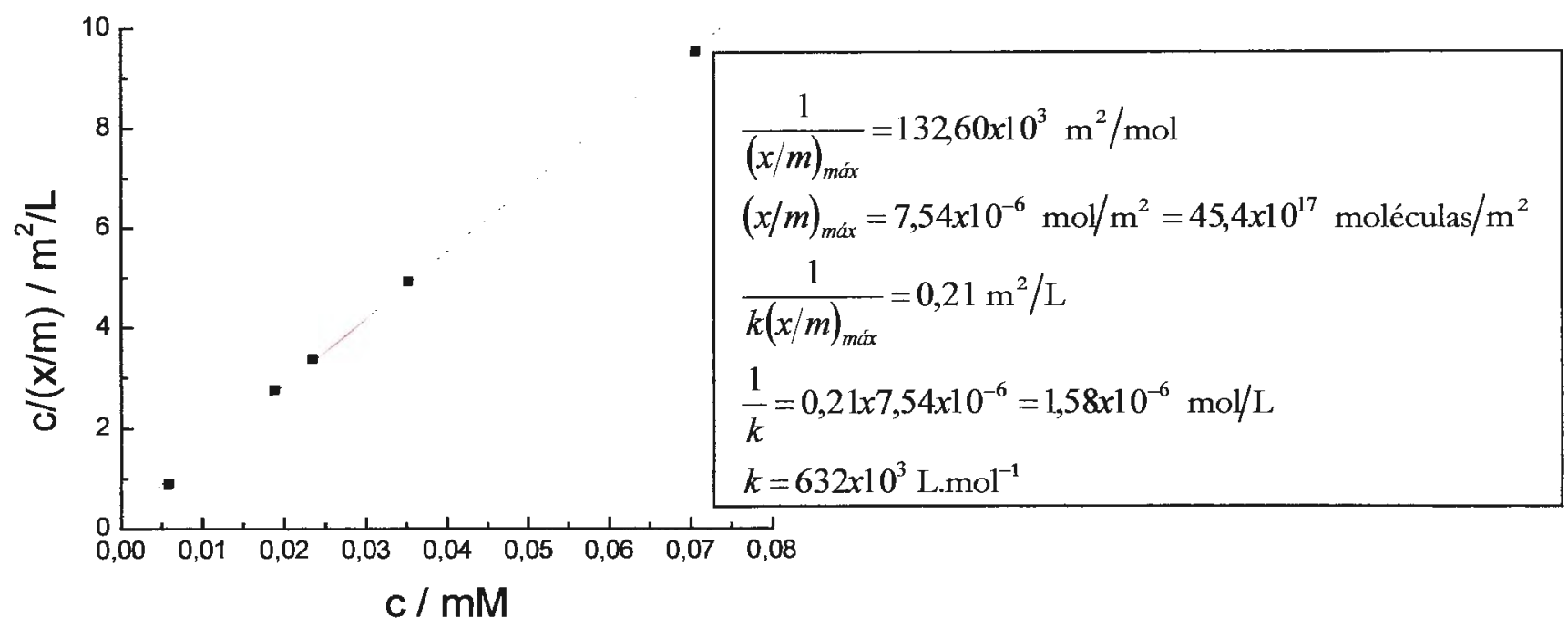

Figura III.2.6 - Linearização da isoterma de adsorção de DODAB a partir de vesículas pequenas sobre partículas de sílica hidrofilica, em tampão Tris $10 \mathrm{mM}, \mathrm{pH}$ 7,4 , a $42{ }^{\circ} \mathrm{C}$, a dispersão de vesículas foi previamente centrifugada.

A tabela III.2.2 mostra as constantes de afinidade e adsorção máxima obtidas pelas linearizações das isotermas de adsorção dos anfifílicos (PC, DPPC e DODAB) sobre sílica hidrofilica.

Tabela III.2.2 - Constantes de afinidade $(k)$ e adsorção máxima $\left((x / m)_{\text {maxx }}\right)$,obtidas pelas linearizações das isotermas de adsorção dos anfifilicos (PC, DPPC e DODAB) sobre sílica hidrofílica em tampão Tris $10 \mathrm{mM}, \mathrm{pH} 7,4$, assim como a adsorção esperada para deposição de uma bicamada $\left(\mathrm{n}_{\text {bicamada }}\right)$.

\begin{tabular}{lcccc}
\hline Vesícula & $\begin{array}{c}\text { Temperatura } \\
{ }^{\circ} \mathrm{C}\end{array}$ & $k$ & $(x / m)_{\text {máx }}$ & $\mathrm{n}_{\text {bicamada }}$ \\
& 25 & $\left.190^{3} \mathrm{~L} \cdot \mathrm{mol}^{-1}\right)$ & $\left(10^{17}\right.$ moléculas $\left./ \mathrm{m}^{2}\right)$ \\
\hline PC & 65 & 239 & 32,4 & 28,6 \\
DPPC & 42 & 632 & 34,4 & 40,0 \\
DODAB & 42 & 45,4 & 33,3 \\
\hline
\end{tabular}


A partir dos linearizações das isotermas de adsorção é possível definir uma ordem de afinidade entre as vesículas e as partículas de sílica hidrofilica: DHP $<$ PC $<$ DPPC $<$ DODAB.

Pode-se discutir a validade do modelo de Langmuir para obtenção dessa ordem de afinidades das diferentes vesículas pela sílica hidrofílica. De fato o modelo foi elaborado para adsorção de monômeros a partir da solução sobre a superfície adsorvente. Todavia, entendendo que a adsorção dos anfifilicos formadores de bicamada se dá a partir de vesículas inteiras Jackson et al, 1987; Camona-Ribeiro e Midmore, 1992] podemos assumir a constante de afinidade como uma constante de afinidade entre a vesícula e a superfície.

III.3 - Deposição de bicamada a partir de vesículas sobre partículas sólidas determinada por oclusão da merocianina 540 .

A figura III.3.1 mostra os espectros ópticos de merocianina 540 (MC540) na presença de três diferentes dispersões de vesículas: PC (figura III.3.1 A), DPPC (figura III.3.1 B) e DODAB (figura III.3.1 C). 


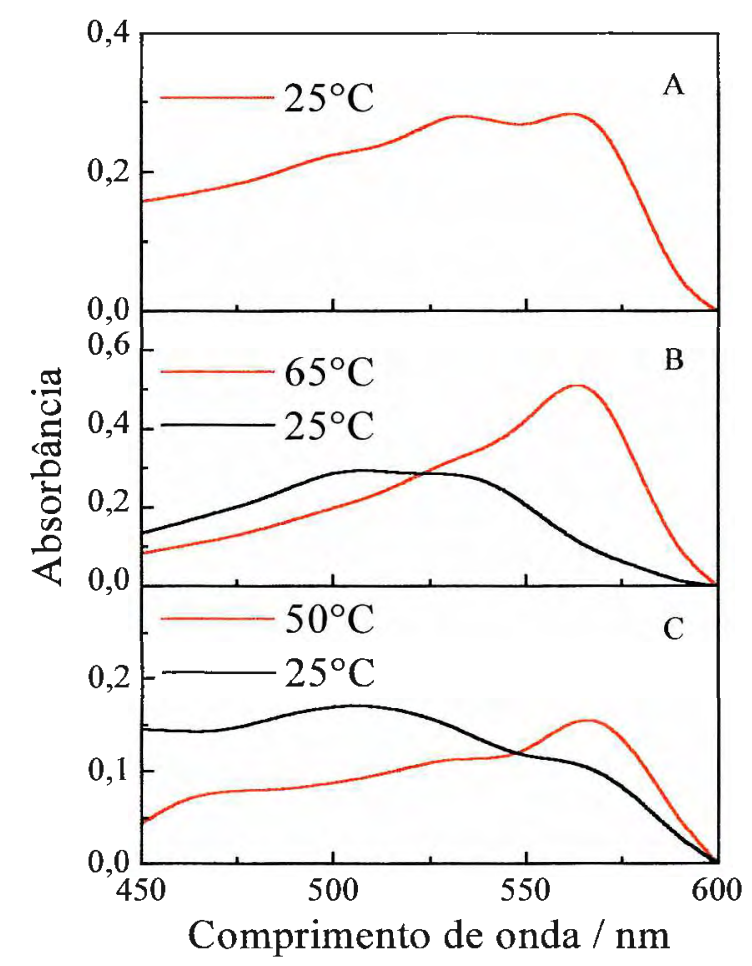

Figura III.3.1 - Espectros ópticos de MC540 incorporada em vesículas de PC (A), DPPC (B), ou DODAB (C), a 1,00, 0,98 e 1,01 mM de lipídio, respectivamente, abaixo (-) ou acima $(-)$ da temperatura de transição de fase. As vesículas foram obtidas por vortexação em água pura de um filme lipídico. A concentração final de MC540 foi fixada em $0,010 \mathrm{mM}$.

Os espectros indicam claramente a dependência da absorção de luz pela MC540 com o estado físico da bicamada e sobre a estrutura química do lipídio em cada tipo de vesícula. Três picos de absorbância podem ser identificados nos espectros: em 565, 530 e $500 \mathrm{~nm}$, previamente descrito como marcador na forma monomérica ou dimérica, ambos ligados à bicamada, ou o marcador na fase aquosa, respectivamente [Lelkes e Miller, 1980; Arroyo et al, 1998]. A relação de intensidade monômero/dímero tem sido relatada como a quantidade de defeitos hidrofóbicos na membrana [Lelkes e Miller, 1980; Arroyo et al, 1998].

A figura III.3.2 mostra uma sugestão da localização da MC540, como monômero, sobre uma bicamada fosfolipídica, esta sugestão foi adaptada de Lelkes e Miller [Lelkes e Miller, 1980]. 


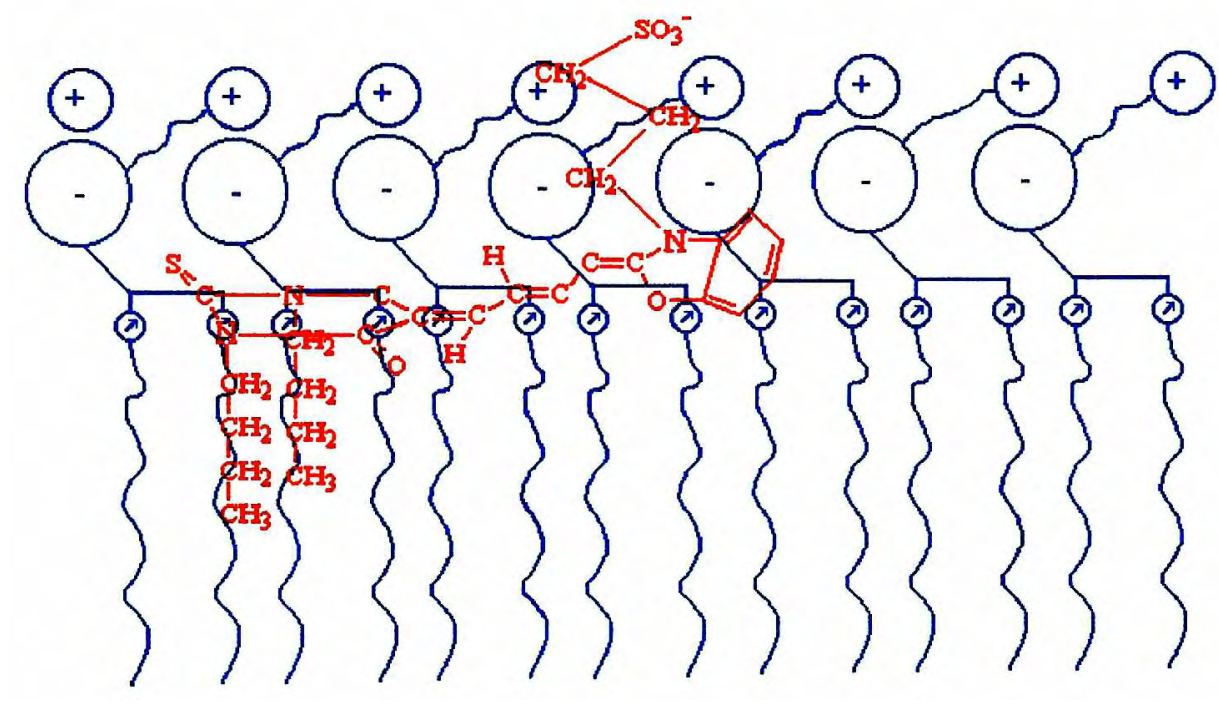

Figura III.3.2 - Localização da merocianina 540 monomérica sobre a superfície de uma bicamada fosfolipídica [Lelkes e Miller, 1980].

Uma vez adicionada ao compartimento externo das vesículas, MC540 irá particionar entre a membrana e a fase aquosa, mostrando um pico de absorbância em $565 \mathrm{~nm}$, que é típico da absorção de monômero incorporado à superfície da bicamada. A fração de oclusão do marcador a partir do marcador monomérico total sobre a dispersão de vesículas irá dar uma medida quantitativa da deposição sobre a sílica em qualquer tempo.

Como a maioria das vesículas foi preparada por injeção etanólica, e o etanol pode causar interdigitação de membranas fosfolipídicas [Komatsu e Rowe, 1991] foi necessário verificar se a merocianina 540 seria capaz de se incorporar em membranas interdigitadas, para isso seria necessário verificar se a presença de etanol modificaria o espectro de absorção de luz pela MC540 em diversas concentrações de etanol. A figura III.3.3 mostra os espectros de absorção de luz pela MC540 em água com diferentes concentrações de etanol, na ausência de qualquer dispersão lipídica. 


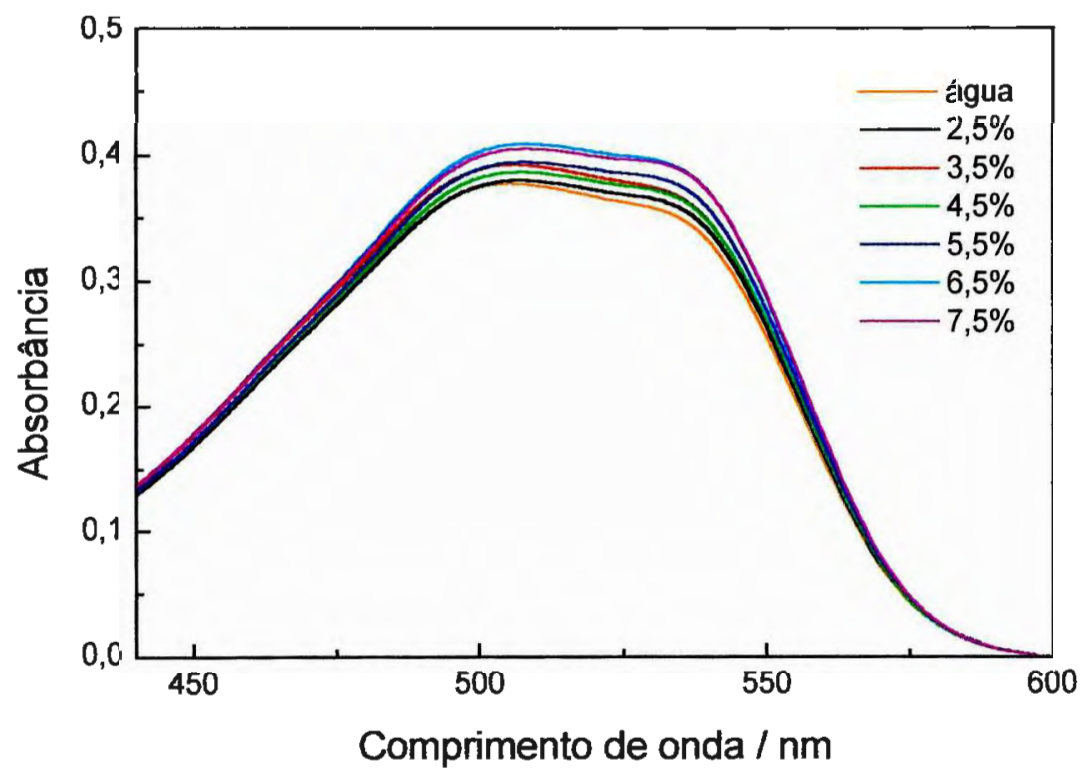

Figura III.3.3 - Espectros de absorção de luz pela MC540 em água com diferentes concentrações de etanol a $25^{\circ} \mathrm{C}$.

Como mostrado na figura III.3.3, os espectros ópticos de MC540 em água e em presença de etanol não são modificados. A presença ou ausência de etanol não interfere no perfil do espectro de absorção de luz pela MC540 em solução. Assim sendo, fomos verificar se a retirada de etanol por diálise exaustiva (4 trocas de 2 litros, 16 horas) alteraria o perfil do espectro de absorção de MC540 em bicamadas. A figura III.3.4 mostra os espectros ópticos de MC540 em presença de vesículas pequenas de PC antes e depois da diálise, com uma concentração inicial de etanol de $7,5 \%$, o que corresponde a 1,29 molar de etanol. 


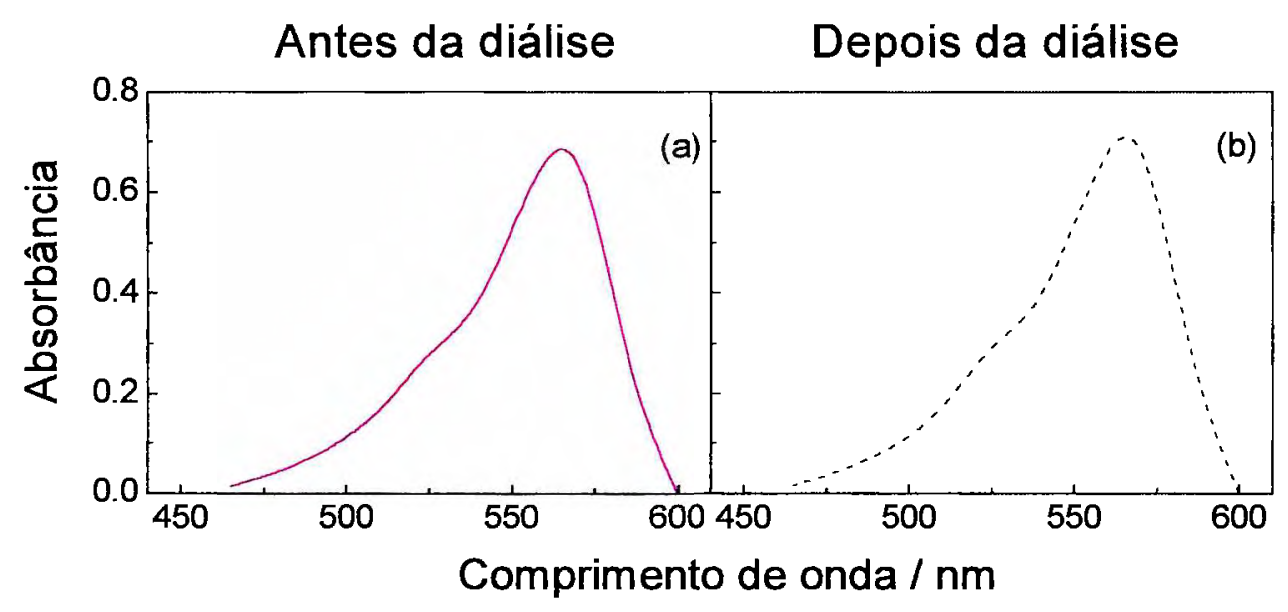

Figura III.3.4 - Espectros de absorção de MC540 em presença de vesículas de PC a $25{ }^{\circ} \mathrm{C}$ obtidas por injeção etanólica, com uma concentração final de etanol de $7,5 \%$, antes (a) e depois (b) da diálise.

Como mostrado pela figura III.3.4, a presença ou ausência de etanol, não interfere no espectro óptico de MC540 em vesículas, o mesmo foi observado para as outras vesículas estudadas: não houve efeito de etanol utilizado para a preparação das vesículas.

A figura III.3.5 mostra os espectros de absorção de luz pela MC540 em presença de vesículas grandes de DPPC, preparadas pelo método de dispersão de filme lipídico em água, na presença de 2,0 mols/ $\mathrm{L}$ de etanol. Também é mostrado o espectro de absorção de luz pela MC540 na presença de vesículas grandes de DPPC preparadas pelo método de injeção etérea na completa ausência de etanol, assim como o espectro de MC540 em água, na ausência de vesículas e etanol. 


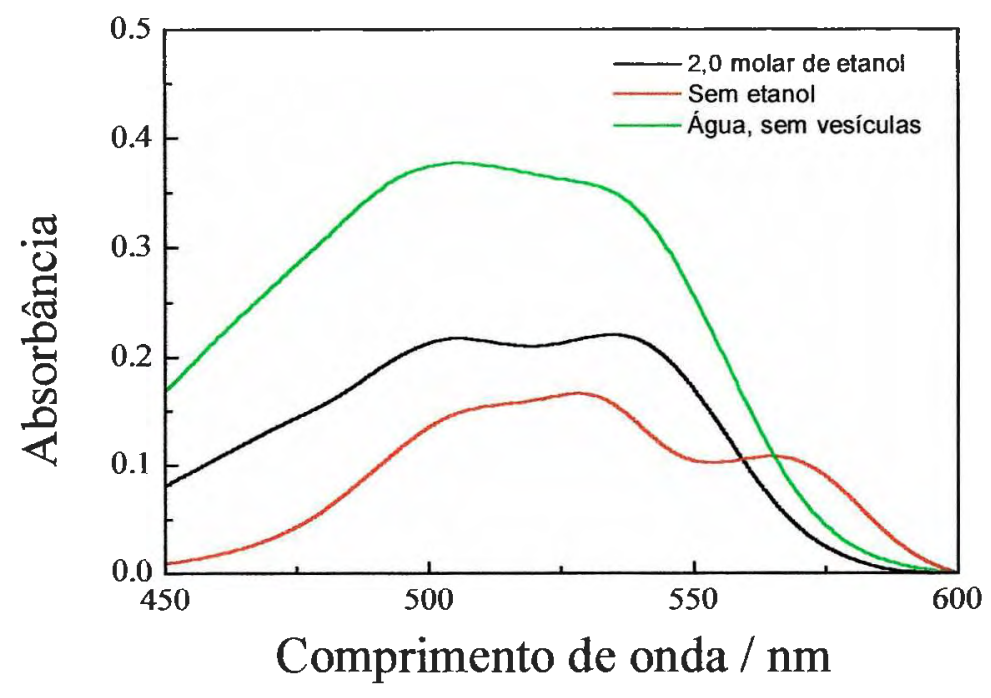

Figura III.3.5 - Espectros de absorção de luz pela MC540 em presença de vesículas grandes de DPPC, preparadas pelo método de dispersão de filme lipídico em água, na presença de 2,0 molar de etanol (-), a concentração de DPPC era de 1,0 mM. O espectro de absorção de luz pela MC540 na presença de vesículas grandes de DPPC preparadas pelo método de injeção etérea na ausência de etanol (-) também é mostrado, a concentração de DPPC era de $0,77 \mathrm{mM}$. O espectro de MC540 em água também é apresentado (-). A concentração de MC540 foi fixada em $10^{-5} \mathrm{mols} / \mathrm{L}$.

Como mostra a figura III.3.5, a presença de $2,0 \mathrm{mols} / \mathrm{L}$ de etanol não modifica o espectro da MC540 em relação ao espectro em água. Quando comparamos o espectro da MC540 com e sem etanol na presença de vesículas grandes de DPPC percebemos que há uma mudança no perfil do espectro, o que significa que a MC540 em presença de vesículas interdigitadas (com 2,0 mols/L de etanol) não se incorpora há membrana. Pelo esquema mostrado na figura III.3.2 podemos verificar que para a MC540 se incorporar na membrana a MC540 necessita que os dipolos do grupamento glicerol estejam alinhados. Para uma membrana interdigitada estes dipolos não estão alinhados, e sim invertidos, assim sendo a MC540 não pode ser incorporada na membrana fosfolipídica interdigitada.

O pico de absorção em da MC540 na forma monomérica ligada à superfície da vesícula foi utilizado para seguir as cinéticas da deposição de bicamada sobre 
partículas de silica. Por oclusão, há a conseqüente redução do pico de absorção a $565 \mathrm{~nm}$ quando a bicamada é depositada sobre a partícula de silica.

As figuras III.3.6, III.3.7 e III.3.8 mostram como varia a absorbância de MC540 a 565 nm com o tempo, na presença de vesículas de PC, DPPC ou DODAB, em tampão Tris ou HEPES $10 \mathrm{mM}$, pH 7,4, na presença ou ausência de partículas de silica.

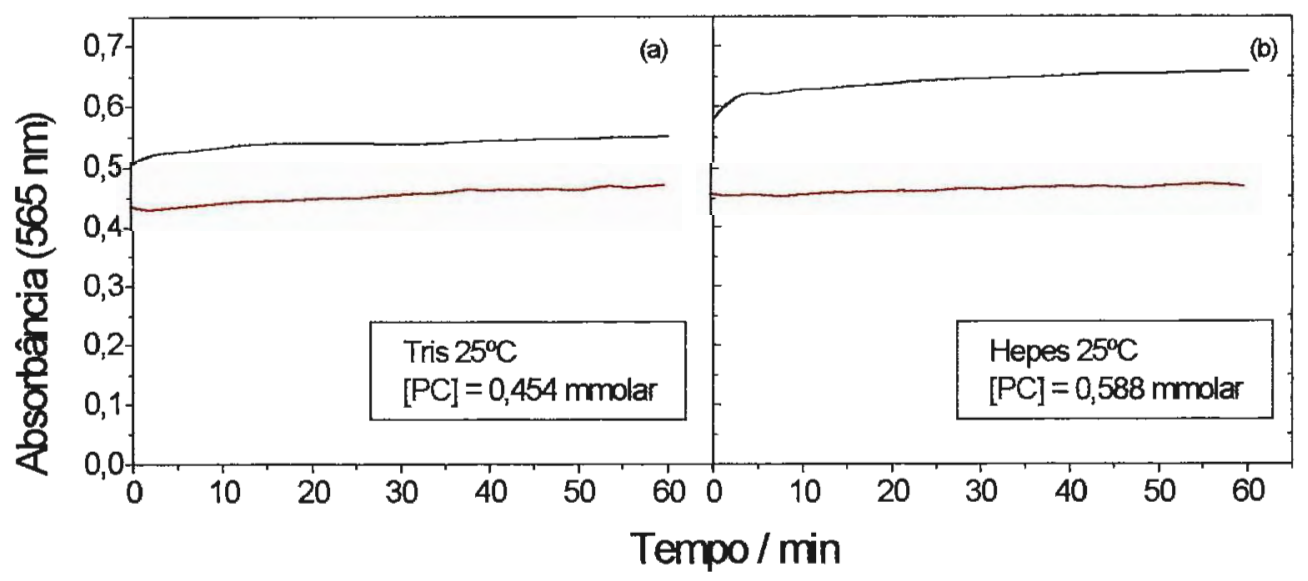

Figura III.3.6 - Cinética de absorção de luz pela MC540 em Tris (a) ou HEPES $10 \mathrm{mM}(\mathrm{b}), \mathrm{pH} 7,4$, a $25^{\circ} \mathrm{C}$ na presença $(-)$ ou ausência $(-)$ de partículas de silica. A área de partículas de sîlica presente é $0,026 \mathrm{~m}^{2}$, a concentração de MC540 em todas as cinéticas é $10^{-5}$ molar. As vesículas foram preparadas por injeção etanólica. A relação entre área de vesículas e área de partículas é de 3,69 (a) e 4,76 (b). 


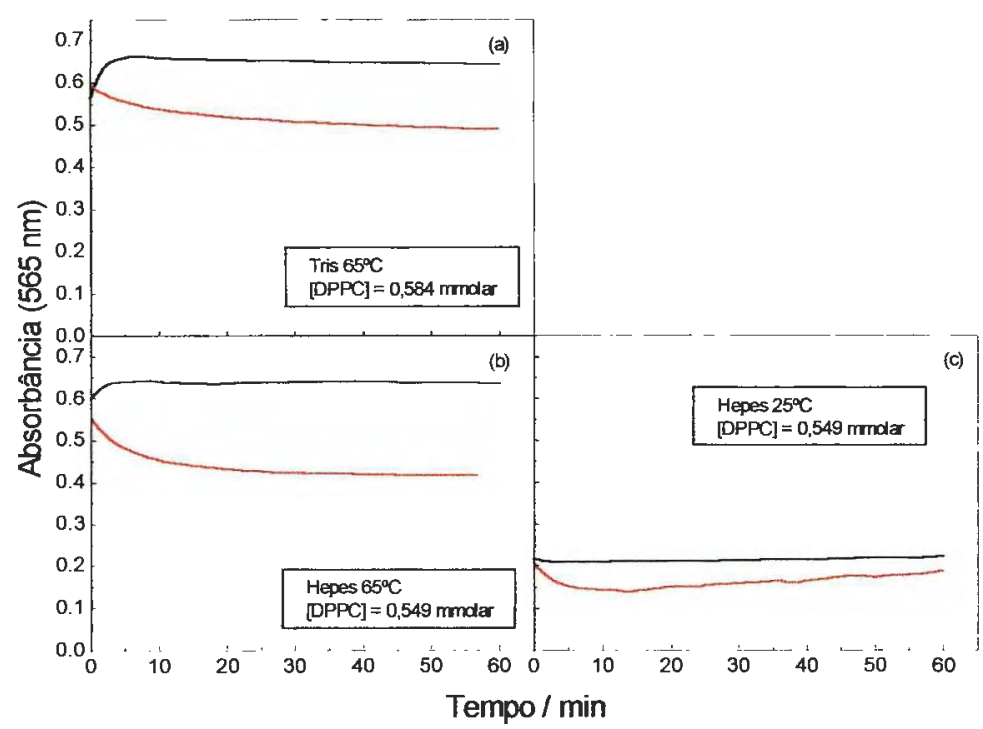

Figura III.3.7 - Cinética de absorção de luz pela MC540 em Tris (a) ou HEPES $10 \mathrm{mM}$ (b), $\mathrm{pH} 7,4$, a $65^{\circ} \mathrm{C}$ ou HEPES, $\mathrm{pH} 7,4$, a $25^{\circ} \mathrm{C}$ (c) na presença $(-$ ou ausência $(\longrightarrow)$ de partículas de silica. A área de partículas de sílica presente é 0,026 $\mathrm{m}^{2}$, a concentração de MC540 em todas as cinéticas é $10^{-5}$ molar. As vesículas foram preparadas por injeção etanólica. A relação entre área de vesículas e área de partículas é de 3,38 (a) e 3,18 (b e c).

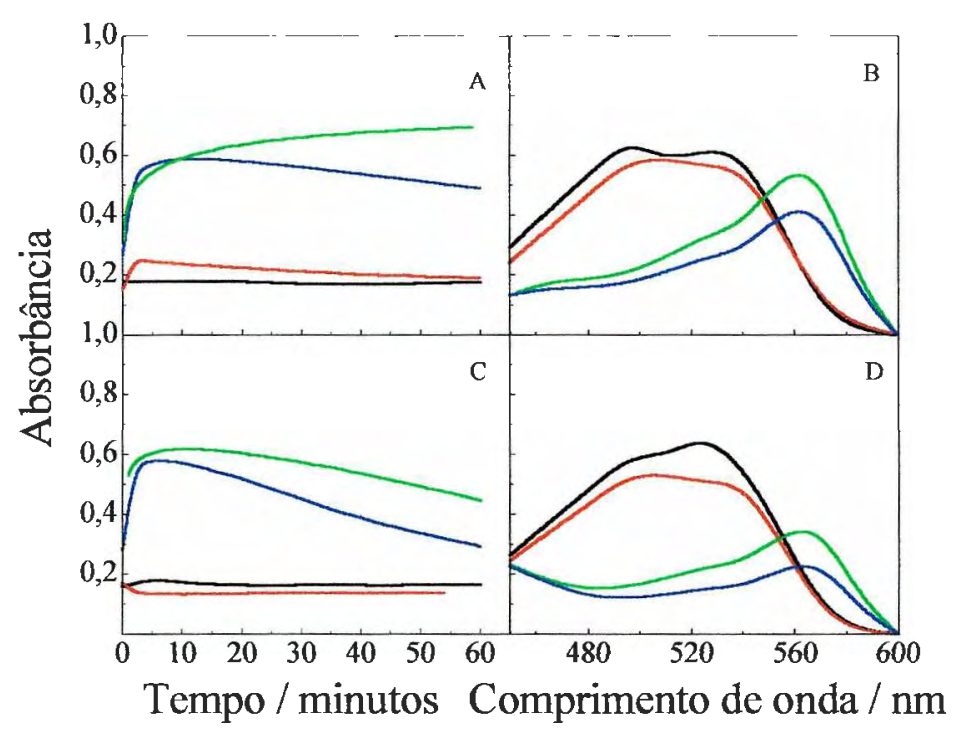

Figura III.3.8 - Absorbância de MC540 a $565 \mathrm{~nm}$ e $25^{\circ} \mathrm{C}$ em função do tempo (A e C) e espectro óptico de MC540 (B e D). MC540 em água ou HEPES (-) ou em $\mathrm{SiO}_{2}(-)$, ou em vesículas pequenas de DODAB (-), que foram preparados por sonicação em água (A e B) ou HEPES, pH 7,4 (C e D), ou em vesículas pequenas misturadas a partículas de sílica (-). Concentração de DODAB é 0,675 (A e B) ou $0,702 \mathrm{mM}$ (C e D). Concentração final de MC540 foi fixada em 0,01 mM. 
Pelas cinéticas apresentadas, podemos verificar que para vesículas pequenas de PC (figura III.3.6), em Tris (a) ou HEPES (b), $\mathrm{pH} 7,4$, as partículas de sílica causam uma diminuição na absorbância de MC540 a $565 \mathrm{~nm}$, o que indica que a MC540 está sendo encapsulada entre a membrana devido ao contato com o particulado de silica.

A figura III.3.7 mostra que na presença de vesículas pequenas de DPPC em Tris (a) ou HEPES (b), pH 7,4 a $65^{\circ} \mathrm{C}$, em contato com as partículas de silica, a MC540 está sendo encapsulada entre a membrana e a partícula de silica, pois a absorbância a $565 \mathrm{~nm}$ diminui com o tempo. Isso pode estar mostrando que as vesículas pequenas de DPPC se rompem e recobrem a silica com uma bicamada, causando a oclusão da MC540 entre a membrana e a partícula.

Uma pequena diminuição da absorbância a $565 \mathrm{~nm}$ é observada para vesículas pequenas de DPPC em tampão HEPES, $\mathrm{pH} 7,4$ a $25^{\circ} \mathrm{C}$ (figura III.3.7, c) o que estaria mostrando que abaixo da temperatura de transição de fase, as vesículas não se rompem ao contatar as partículas de sílica, ocorrendo apenas adesão das vesículas sobre as partículas de silica.

Para MC540 incorporada na superfície externa de vesículas pequenas de DODAB, o efeito das partículas de sílica sobre absorbância a $565 \mathrm{~nm}$ em função do tempo é mostrado na figura III.3.8 A e C. Todos os controles essenciais foram feitos para mostrar, por exemplo, que as partículas não causam mudanças no espectro da MC540 obtida em água pura (Figura III.3.8 B e D), mas as partículas adicionadas à membrana causam redução da absorbância da MC540, previamente incorporada na membrana, a $565 \mathrm{~nm}$. A porcentagem de redução permite calcular a fração de moléculas de lipídios que contribuem para oclusão do marcador (tabela III.3.1). Essa tabela mostra a quantidade para o número de moléculas de lipídio que contribuem para a oclusão por metro quadrado de sílica depois de 1 hora de 
interação, $\mathrm{n}_{\text {ads, } 1 \mathrm{~h}}$, que são muito similares àqueles obtidos pelas isotermas de adsorção.

Tabela III.3.1 - Oclusão de MC540 a partir da redução a $565 \mathrm{~nm}$ depois da interação entre vesículas unilamelares lipídicas com MC540 adsorvida na superfície externa e sílica. A redução total de absorbância $(\Delta \mathrm{A})$ em 1 hora de interação entre vesículas e partículas foi calculado como uma porcentagem da absorbância sem as partículas $\left(A_{v}\right)$ quando às vesículas marcadas externamente com MC540 foi adicionada a dispersão de sílica a uma área superficial final de $0,026 \mathrm{~m}^{2}$. A partir da porcentagem de redução, o número de moléculas de lipídios adsorvidas sobre sílica $\left(\mathrm{n}_{\mathrm{ads}, 1 \mathrm{~h}}\right)$ foi calculado. Vesículas de PC e DPPC foram obtidas por injeção etanólica, enquanto vesículas de $\mathrm{DODAB}$ foram obtidas por sonicação. A concentração de lipídio final C está expressa em mM.

\begin{tabular}{|c|c|c|c|c|}
\hline \multirow{2}{*}{$\begin{array}{r}\text { Lipídio/C } \\
\mathrm{mM}\end{array}$} & Tampão/temperatura & \multirow[t]{2}{*}{$100 \Delta \mathrm{A} / \mathrm{A}_{\mathrm{v}}$} & $\mathrm{n}_{\mathrm{ads}, 1 \mathrm{~h}}$ & $\mathrm{n}_{\text {bicamada }}$ \\
\hline & ${ }^{\circ} \mathrm{C}$ & & \multicolumn{2}{|c|}{$/ 10^{17}$ moléculas $\mathrm{m}^{-2}$} \\
\hline $\mathrm{PC} / 0,454$ & Tris $/ 25$ & 13,8 & 14,7 & 28,6 \\
\hline PC/0,588 & HEPES/25 & 28,3 & 38,8 & 28,6 \\
\hline $\mathrm{DPPC} / 0,584$ & Tris/ 65 & 26,6 & 36,3 & 40,0 \\
\hline $\mathrm{DPPC} / 0,549$ & HEPES/ 65 & 33,9 & 43,5 & 40,0 \\
\hline $\mathrm{DPPC} / 0,549$ & HEPES/25 & 14,9 & 19,2 & 40,0 \\
\hline $\mathrm{DODAB} / 0,675$ & ÁGUA/25 & 28,3 & 44,3 & 33,3 \\
\hline DODAB $/ 0,702$ & HEPES/25 & 33,8 & 54,9 & 33,3 \\
\hline
\end{tabular}

Em temperatura ambiente, a deposição de bicamada fosfolipídica não parece ser completa e/ou pode ser correspondente à mera agregação de vesículas sobre partículas de sílica como descrito a partir dos valores de $\mathrm{n}_{\mathrm{ads}, 1 \mathrm{~h}}$ que desviam dos valores esperados para deposição de bicamada (tabela III.3.1). No entanto, para vesículas de DPPC misturadas com sílica a $65^{\circ} \mathrm{C}$, há uma boa concordância entre $\mathrm{n}_{\mathrm{ads}, 1 \mathrm{~h}}$ e o valor esperado para deposição de bicamada. Possivelmente, deposição de bicamada a temperatura ambiente pode ocorrer depois de um longo tempo e altas concentrações de fosfolipídios para se tornar completa devido à baixa afinidade dos fosfolipídios pela superfície de sílica. 
Para a adsorção de DODAB sobre sillica, este método indica uma deposição superior ao que seria esperado para adsorção de bicamada. As isotermas de adsorção de DODAB sobre sílica (figuras III.2.2, III.2.3, e III.2.4) mostram que a adsorção é maior do que o esperado para deposição de bicamada para concentrações inferiores a $1,0 \mathrm{mM}$.

As figuras III.3.9, III.3.10, III.3.11 mostram as cinéticas de adsorção de PC, DPPC ou DODAB, respectivamente, sobre sílica hidrofilica. As adsorções foram obtidas das cinéticas de absorção de luz pela MC540 na presença de vesículas e partículas de sílica.

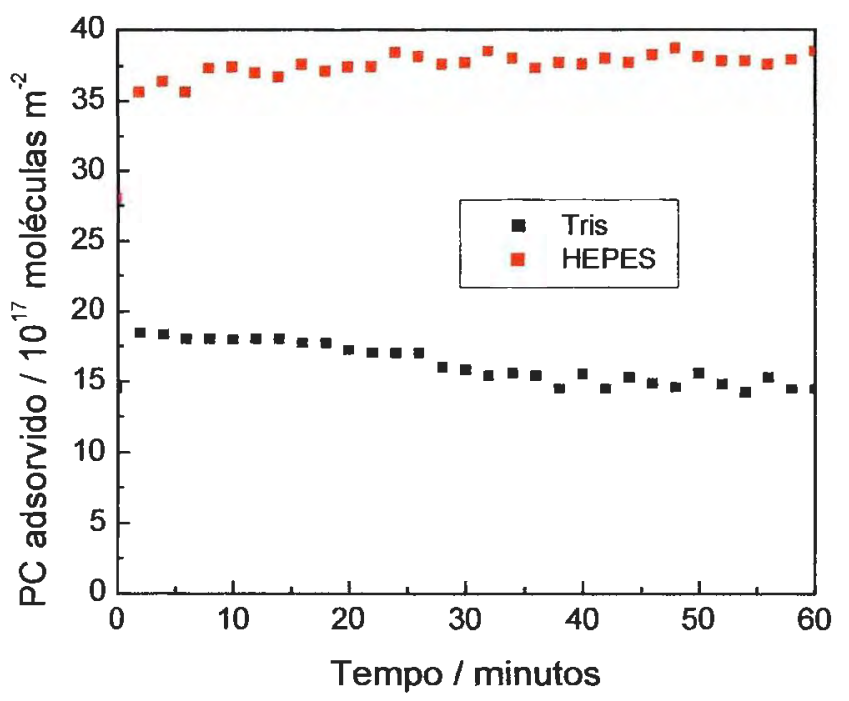

Figura III.3.9 - Cinética de adsorção de PC sobre silica hidrofilica em Tris ( HEPES ( $\square$ ). As concentrações de PC nas misturas eram $0,454 \mathrm{mM}$ em Tris e 0,588 $\mathrm{mM}$ em HEPES. As cinéticas foram obtidas a partir da redução de absorção de luz pela MC540 em presença de partículas de sílica. 


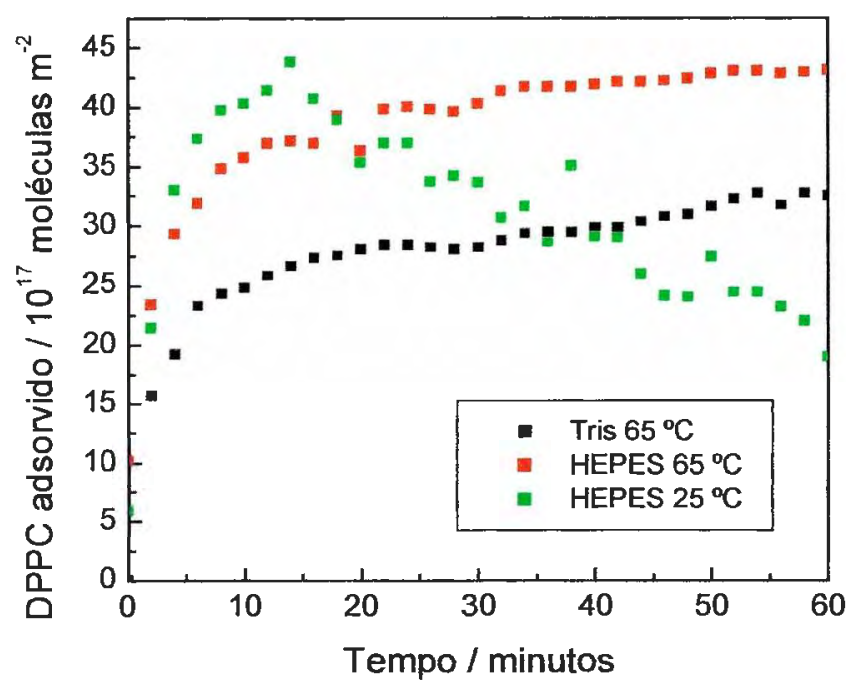

Figura III.3.10 - Cinética de adsorção de DPPC sobre sílica hidrofilica em Tris (ロ) ou HEPES ( misturas eram $0,584 \mathrm{mM}$ em Tris e $0,549 \mathrm{mM}$ em HEPES. As cinéticas foram obtidas a partir da redução de absorção de luz pela MC540 em presença de partículas de sílica.

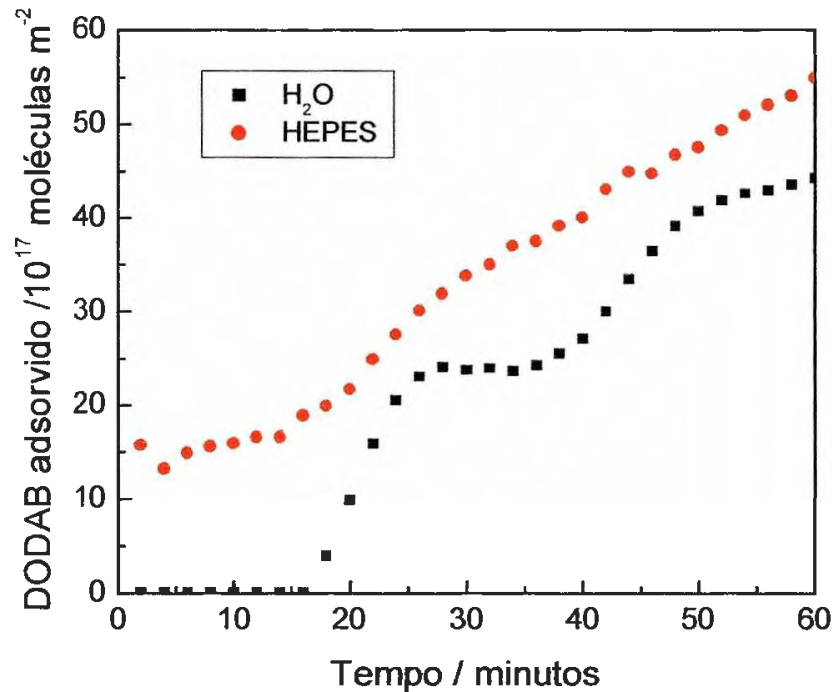

Figura III.3.111 - Cinética de adsorção de DODAB sobre súlica hidrofilica em água $(\bullet)$ ou HEPES $(\bullet)$ a $25^{\circ} \mathrm{C}$. As concentrações de DODAB nas misturas eram $0,675 \mathrm{mM}$ em água e 0,702 $\mathrm{mM}$ em HEPES. As cinéticas foram obtidas a partir da redução de absorção de luz pela MC540 em presença de partículas de silica.

Podemos perceber que o equilíbrio na adsorção de PC a $25{ }^{\circ} \mathrm{C}$ e DPPC a $65^{\circ} \mathrm{C}$ sobre silica ocorre por volta de 10 minutos (figura III.3.9), enquanto que para 
as vesículas de DPPC a $25^{\circ} \mathrm{C}$ este cquilibrio não ć alcançado, ocorrendo a desorção das vesículas de DPPC (figuta III.3.10).

Nas cinćticas de absorção de DODAB sobre as partículas de sullica também não é obscrvado equilition, c sim um aumcnto contínuo da adsorģão com o tempo.

A figura III.3.12 mostra o modclo que explicaria a reduçăo da absorção do luz pcla MC540 ao scr oclusa cntre a partícula c a tncmbrana.
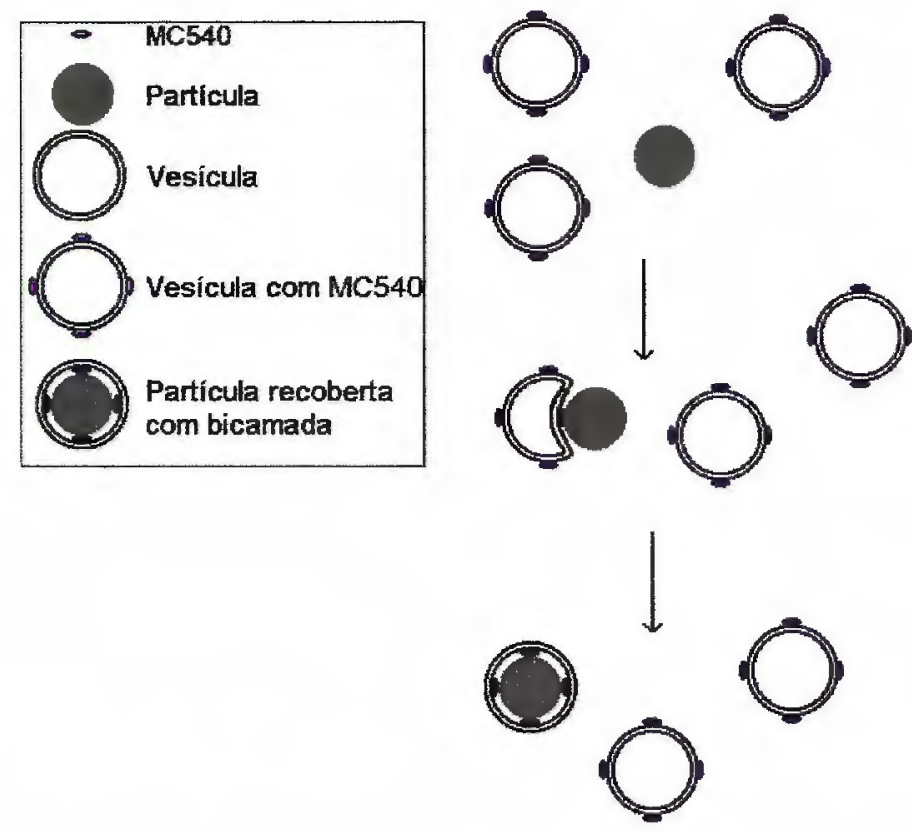

Figura III.3.12 - Modelo de interação entre partículas de sílica e vesículas que contenham MC540 incorporada, mostrando o cncapsulamento da MC540 cntre a membrana c a partícula de stica.

No modelo da figura M.3.12 sugerido que vesículas com MC540 incorporada na supcrficic cxterna da bicamada, ao cntrat con contato com particulas sólidas sc cutvatiam sobre a pattícula, causando o tompincnto da membrana com subseqüente recobtimcnto da partícula c cncapsulamento da MC540 cnire a patécula c a bicamada depositada. Esta oclusão da MC540 causa uma diminuição la absorbância cm todo o cspectro da MC540, como observado na figura III.3.8. 


\section{III.4 - Efeito de vesículas sobre a molhabilidade de óxido de sílicio.}

O efeito da presença de vesículas sobre a molhabilidade das superfícies planares de óxido de silício foi determinado por medidas de ângulo de contato, utilizando o método de Wilhelmy modificado.

A figura III.4.1 mostra as curvas típicas de variação de massa aparente durante o avanço e recesso da superfície de $\mathrm{SiO}_{2}$ em contato com uma dispersão de vesículas de DPPC, após 1 hora de interação.

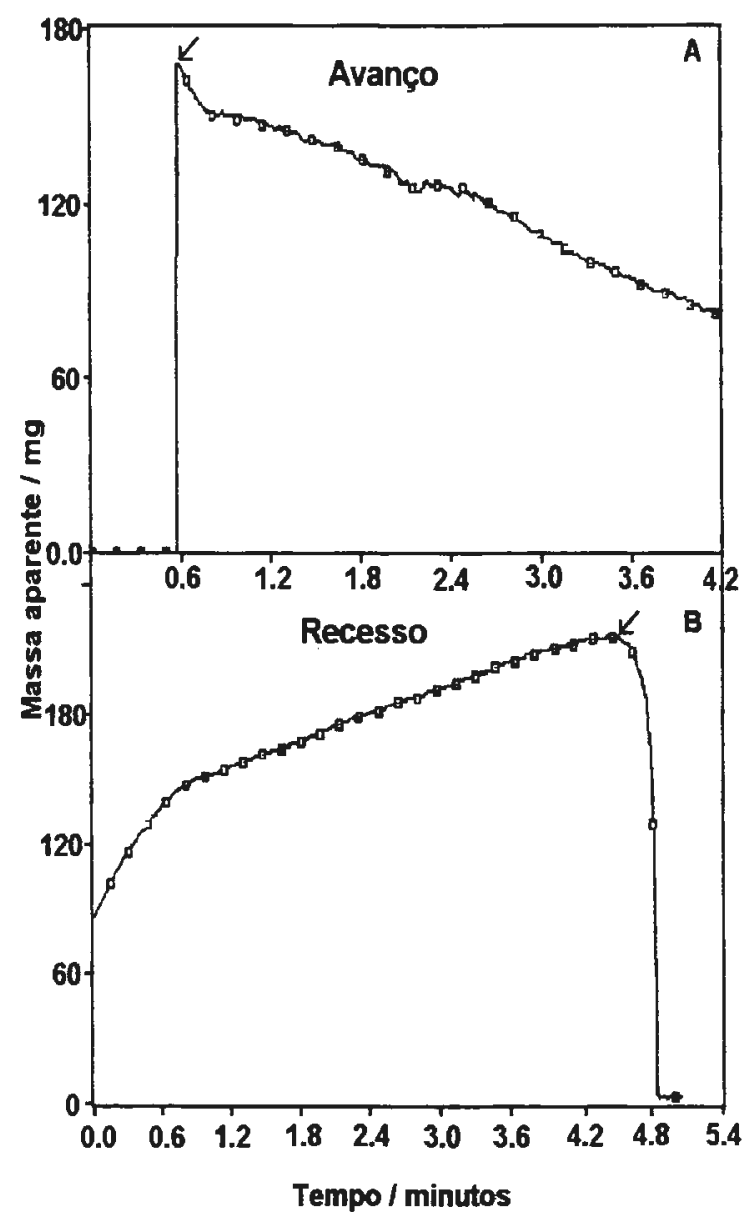

Figura III.4.1 - Curvas típicas de variação de massa aparente com o tempo durante o avanço (A) ou recesso (B) da superfície de $\mathrm{SiO}_{2}$ em contato com uma dispersão de vesículas de DPPC, após 1 hora de interação.

A massa aparente na curva de avanço (figura III.4.1 A) parte de zero, pois neste momento a lâmina de $\mathrm{SiO}_{2}$ está presa ao Dynometer, e sem contato com a 
dispersão de vesículas, e o massa medida pelo Dynometer é zerado. A plataforma com a dispersão de vesículas é movimentada em direção à lâmina de $\mathrm{SiO}_{2}$, em uma velocidade de $1,5 \mathrm{~mm} / \mathrm{min}$, quando a lâmina entre em contato com a dispersão de vesículas é observado um aumento abrupto na massa aparente, neste instante a massa aparente medida é a massa de dispersão de vesículas que molha a superfície. A partir do momento que a lâmina de $\mathrm{SiO}_{2}$ entra na dispersão de vesículas a massa aparente diminui, devido ao empuxo exercido sobre a lâmina de $\mathrm{SiO}_{2}$.

A curva de recesso (figura III.4.1 B) começa no valor de massa aparente em que o avanço foi interrompido. Durante o recesso a plataforma com a dispersão de vesículas é movida para baixo em uma velocidade de $1,5 \mathrm{~mm} / \mathrm{min}$. A massa aparente observada aumenta em função do tempo devido à diminuição do empuxo, atingindo um máximo, que corresponde ao instante em que a lâmina irrompe da dispersão de vesículas, e neste instante o empuxo é zero, e a massa aparente medida é a massa de dispersão de vesículas que molha a lâmina de $\mathrm{SiO}_{2}$. Então, a massa aparente retorna a zero, pois a massa da lâmina foi zerada no início do avanço.

Os pontos indicados na figura III.4.1 representam as massas utilizadas para o cálculo de ângulo, ou seja, é a massa aparente no momento em que a superfície sólida $\left(\mathrm{SiO}_{2}\right)$ entra em contato com a superfície líquida (dispersão de vesículas), neste momento o empuxo exercido pela solução é zero e a massa aparente medida é igual a massa de água que molha a superfície.

A tabela III.4.1 mostra os valores de tensão superficial, ângulo de contato dinâmico e histerese do ângulo de contato dinâmico entre a superfície de $\mathrm{SiO}_{2}$ e dispersões de vesículas pequenas de PC, DPPC ou DODAB em Tris ou HEPES $10 \mathrm{mM}, \mathrm{pH} 7,4$, a $25^{\circ} \mathrm{C}$ e DPPC em Tris $10 \mathrm{mM}$ pH 7,4 a $65^{\circ} \mathrm{C}$. A condição experimental escolhida foi aquela correspondente à adsorção de bicamada obtida pelas isotermas de adsorção sobre o particulado. Como a área disponível na lâmina de $\mathrm{SiO}_{2}\left(2,754 \mathrm{~cm}^{2}\right)$ é muito menor que aquela do particulado $\left(260 \mathrm{~cm}^{2}\right)$, as 
concentrações finais de lipídio utilizadas foram proporcionalmente menores e na faixa de micromolares.

Tabela III.4.1 - Tensão superficial $(\gamma)$, ângulo de contato dinâmico $(\theta)$ de avanço e recesso e histerese de ângulo de contato entre superfície de $\mathrm{SiO}_{2}$ e dispersões de vesículas pequenas de PC, DPPC ou DODAB, em Tris ou HEPES, $\mathrm{pH} 7,4$, a $25^{\circ} \mathrm{C}$ e DPPC em Tris $\mathrm{pH} 7,4$ a $65^{\circ} \mathrm{C}$ após 1 hora de interação.

\begin{tabular}{|c|c|c|c|c|c|c|c|}
\hline Vesícula & Meio & $\begin{array}{c}\text { Concentração } \\
\mu \mathrm{M}\end{array}$ & $\begin{array}{c}\text { Temperatura } \\
{ }^{\circ} \mathrm{C}\end{array}$ & $\begin{array}{c}\gamma \\
\mathrm{mN} / \mathrm{m}\end{array}$ & $\theta_{\text {avanço }}$ & $\begin{array}{l}\theta_{\text {recesso }} \\
\text { Graus }\end{array}$ & Histerese \\
\hline- & Água & - & 25 & 72,8 & $20 \pm 4$ & 0 & $20 \pm 4$ \\
\hline \multirow[t]{2}{*}{$\mathrm{PC}$} & HEPES 7,4 & 6,3 & 25 & 66,9 & 0 & 0 & 0 \\
\hline & Tris 7,4 & 4,9 & 25 & 67,7 & $8 \pm 6$ & 0 & $8 \pm 6$ \\
\hline \multirow[t]{3}{*}{ DPPC } & HEPES 7,4 & 5,8 & 25 & 68,6 & $29 \pm 5$ & $6 \pm 8$ & $23 \pm 13$ \\
\hline & Tris 7,4 & 6,3 & 25 & 68,9 & $21 \pm 5$ & $3 \pm 3$ & $19 \pm 7$ \\
\hline & Tris 7,4 & 6,3 & 65 & 46,9 & $48 \pm 3$ & $9 \pm 8$ & $38 \pm 6$ \\
\hline \multirow[t]{2}{*}{ DODAB } & HEPES 7,4 & 13,8 & 25 & 64,6 & $66 \pm 1$ & $43 \pm 2$ & $22 \pm 2$ \\
\hline & Tris 7,4 & 13,2 & 25 & 65,3 & $71 \pm 3$ & $50 \pm 1$ & $21 \pm 2$ \\
\hline
\end{tabular}

Pelos valores de tensão superficial, podemos perceber que não há grande adsorção dos anfifílicos na interface ar/água, pois os valores de tensão superficial das dispersões de vesículas a $25^{\circ} \mathrm{C}$ e água são bastante próximos.

$A$ tensão superficial da água a $65^{\circ} \mathrm{C}$ é $65,15 \mathrm{mN} / \mathrm{m}$, enquanto que a obtida para dispersão de DPPC a $65^{\circ} \mathrm{C}$ é $46,9 \mathrm{mN} / \mathrm{m}$, esta diferença está mostrando que com o aumento da temperatura as vesículas fundem na interface ar água. A dependência da tensão superficial de dispersões de vesículas com a temperatura já foi usada por Gugliotti et al para determinação da temperatura de transição de fase de vesículas, uma vez que é justamente na temperatura de transição de fase que as mesmas se fundem com a interface ar/água gerando uma diminuição abrupta da tensão superficial [Gigliotti et al. 1998]. É bem conhecido que durante a transição de fase de bicamadas, a coexistencia dos estados gel e líquido cristalino produzem defeitos hidrofóbicos na estrutura da bicamada [Gugliotti et al, 1998]. 
Pelos dados de ângulo de contato dinâmico apresentados, podemos observar que há uma aumento no valor de ângulo de contato entre a superfície de $\mathrm{SiO}_{2} \mathrm{e}$ vesículas de DPPC a $65^{\circ} \mathrm{C}$, enquanto que para vesículas de DPPC a $25^{\circ} \mathrm{C}$ o vaır permanece inalterado, quando comparado com o ângulo de contato entre a superfície de $\mathrm{SiO}_{2}$ e água. Isso pode estar indicando um rompimento das vesículas quando entram em contato com a superfície de $\mathrm{SiO}_{2}$, a $65^{\circ} \mathrm{C}$, deixando expostas para o ar as cadeias hidrocarbônicas quando a superfície é retirada da dispersão de vesículas.

$\mathrm{O}$ ângulo de contato dinâmico entre a superfície de $\mathrm{SiO}_{2}$ e vesículas de PC, mostra uma diminuição do ângulo de contato de avanço quando comparada com o valor de ângulo de contato de avanço entre $\mathrm{SiO}_{2}$ e água, o que poderia estar indicando que as vesículas não estão adsorvendo sobre a superfície. Por estarmos trabalhando com concentrações muito baixas de anfifilicos, as vesículas de PC poderiam estar adsorvendo sobre as paredes do béquer, não restando $\mathrm{PC}$ em concentração suficiente para adsorver sobre a superfície de $\mathrm{SiO}_{2}$.

$\mathrm{O}$ ângulo de contato dinâmico entre a superfície de $\mathrm{SiO}_{2}$ e vesículas de DODAB, mostra uma diminuição na hidrofilicidade da superfície após 1 hora de interação, pois o valor do ângulo de contato é maior quando comparado com o valor de ângulo de contato dinâmico entre $\mathrm{SiO}_{2}$ e água, o que pode estar indicando que as vesículas estão rompendo, deixando suas cadeias hidrofóbicas expostas para o ar quando a superfície é retirada da dispersão de vesículas. $O$ valor de ângulo de contato dinâmico de avanço concorda com aquele que já foi obtido pela técnica de gota séssil por Claesson, entre uma superfície de mica, um alumino-silicato, e uma dispersão de DODAB em força iônica de 10 mM [Claesson et al., 1986].

Pelos valores de histerese que foram obtidos podemos dizer que há uma grande heterogeneidade sobre a superfície de $\mathrm{SiO}_{2}$, sendo esta heterogeneidade sendo causada pela presença de rugosidade na superfície, ou pela heterogeneidade 
química na superfície causada pela presença dos anfifilicos sobre a superfície de $\mathrm{SiO}_{2}$.

Os valores de ângulo de contato de avanço entre as dispersões de vesículas e superfície de $\mathrm{SiO}_{2}$ segue a seguinte seqüência: DODAB $>$ DPPC $>$ PC, a mesma seqüência observada para as afinidades entre as vesículas e as partículas de sílica obtidas pelas isotermas de adsorção. 


\section{IV - Conclusões}

As afinidades das vesículas pelas partículns de sílica obtidas pelas isotermas de adsorção seguem a seguinte seqüência: $\mathrm{DODAB}>\mathrm{DPPC}>\mathrm{PC}>\mathrm{DHP}$.

A centrifugação das dispersões de vesículas fosfolipídicas preparadas por injeção etanólica é um procedimento que evita a superestimativa da adsorção destas vesículas sobre as partículas de sílica.

Devido a repulsão eletrostática existente as vesículas de DHP (negativamente carregadas) e as partículas de silica, também negativamente carregadas, a menor afinidade pela sílica foi a do DHP.

A afinidade das vesículas fosfolipídicas, DPPC e PC, acima da temperatura de transição de fase é maior na presença de tampão Tris em valores de $\mathrm{pH}$ menores ou iguais a 7,4, isto é devido a adsorção do Tris sobre as partículas de sílica. Esta adsorção de Tris aumenta a densidade superficial de grupos $-\mathrm{OH}$ disponíveis para a formação de pontes de hidrogênio entre os grupamentos $-\mathrm{OH}$ do Tris e $-\mathrm{P}=\mathrm{O}$ dos fosfolipídios.

A adsorção de DODAB sobre as partículas de sílica é dirigida via formação de par iônico entre os grupos silanóis dissociados da silica e o grupo amônio quaternário do DODAB. Esta adsorção é favorecida por valores de $\mathrm{pH}$ mais altos, em presença de tampão HEPES, pois nesses valores de $\mathrm{pH}$ a densidade superficial de carga da sílica é maior, o que favorece a formação de pares iônicos.

MC540 não se incorpora a bicamadas fosfolipídicas interdigitadas.

A adição de partículas sólidas em dispersões de vesículas marcadas na superfície externa com MC540 causa uma diminuição da intensidade de luz absorvida pela MC540, que indica a oclusão da MC540 entre as partículas e vesículas. A partir da redução total de absorção de luz pela MC540 é possível inferir sobre a quantidade de anfifilico depositada sobre a partícula. 
A molhabilidade da superfície de $\mathrm{SiO}_{2}$ sob condições de adsorção de bicamada em presença de vesículas fosfolipídicas mostrou um grande aumento na hidrofobicidade da superfície para DPPC a $65^{\circ} \mathrm{C}$ e DODAB a teıperatura ambiente, indicando maior hidrofobicidade da superfície. Este aumento na hidrofobicidade da superfície de $\mathrm{SiO}_{2}$ está de acordo com o esperado para deposição de bicamadas sob a água e uma monocamada com cadeias hidrocarbônicas expostas para o ar.

As três metodologias empregadas (isotermas de adsorção, redução da absorção de luz pela MC540 e ângulo de contato dinâmico) mostram a deposição de bicamada de DODAB e DPPC sobre as superfícies de sílica na fase aquosa. 


\section{V - Perspectivas}

As perspec ivas futuras para continuidade deste trabalho são:

1) Determinar as cinéticas de adsorção dos anfifilicos sobre as partículas de silica nas mesmas condições das cinéticas obtidas pela redução de absorção de luz pela MC540 em presença de partículas de sílica, talvez por um método de filtração rápida em membranas de policarbonato.

2) Resolver a baixa afinidade dos fosfolipídios neutros pela silica hidrofilica em baixa força iônica utilizando sllica hidrofóbica como suporte.

3) Resolver a baixa afinidade dos fosfolipídios neutros pela silica hidrofílica alterando a força iônica do meio para $150 \mathrm{mM}$ (força iônica fisiológica), pois a atração de van der Waals irá aumentar com o aumento da força iônica.

4) Determinar o efeito de $\mathrm{pH}$ sobre as densidades superficiais de carga em diferentes soluções tampão e correlacionar com as medidas de adsorção de vesículas de carga oposta.

5) Determinar tamanhos e densidades superficiais de carga das partículas hidrofilicas de silica antes e depois do recobrimento com membranas, a partir de determinações de "light scattering" dinâmico ou de potenciais-zeta usando um ZetaPlus equipado com autocorrelator.

6) Determinar o efeito de partículas de silica sobre a tensão superficial de dispersões contendo anfifilicos em função do tempo e da concentração de anfifilico ou particulado.

7) Determinar a molhabilidade de superfícies planas de óxido de silício em presença das vesículas de PC, DPPC ou DODAB em função da concentração do anfifílico, fixo o tempo de interação vesícula/superfície, e do tempo de interação vesícula / superfície, fixa a concentração de anfifilico. 
8) Determinar ângulo de contato estático de superfícies planares de $\mathrm{SiO}_{2}$ em presença de vesículas de PC, DPPC ou DODAB através de medidas utilizando a técnica da gota séssil, para comparar com o ângulo de contato dinâmico.

9) Determinar a espessura do filme formado sobre superfícies planares de óxido de silício através de medidas elipsométricas.

10) Definir um possivel uso de partículas de silica recobertas com bicamada para amplificar o reconhecimento biomolecular. Como par receptor-ligante cujo reconhecimento poderá ser amplificado sobre partículas-suporte de silica recobertas com fosfolipídio, propomos o par monosialogangliosídeo-toxina da cólera. Assim, o reconhecimento anteriormente amplificado em partículas de poliestireno [Sicchierolli e Carmona-Ribeiro, 1995; Sicchierolli e Carmona-Ribeiro, 1996] será tentativamente amplificado em silica hidrofóbica ou hidrofilica recoberta com fosfolipídios. 


\section{VI - Referências Bibliográficas}

ADAMS, A. C. Dieletric and polysilicon film deposition. In: CZE, S. M. VLSI Technology. Singapore, McGraw-Hill, 1990, p.93-129.

ARCHIBALD, D. D.; MANN, S. Template mineralization of self-assembled anisotropic lipid microstructures. Nature, v.364, p.430-433, 1993.

ARROYO, J.; DE LOPEZ, A. C. BB.; BERNIK, D. L.; DISALVO, E. A. Surface packing of lipid bilayer in the gel state induced by osmotic stress as measured by the dimerization of merocyanine 540. J. Colloid Interface Sci., v.203, p.106-114, 1998.

AZZAM, R. M. A.; BASHARA, N. M. Ellipsometry and polarized light. 1 ed., Netherlands, North Holland Personal Library, 1987.

BANGHAM, A. D.; DE GIER, J.; GREVILLE, G. D. Osmotic properties and water permeability of phospholipid liquid crystals. Chem. Phys. Lipids, v.1, p.225-146, 1967.

BATZRI, S.; KORN, E. D. Single bilayer liposomes prepared without sonication. Biochim. Biophys. Acta., v.298, p.1015-1019, 1973.

BRINCK, J.; JÖNSSON, B.; TIBERG, F. Influence of long-chain alcohols on the adsorption of nonionic surfactants to silica. Langmuir, v.15, p.7719-7724, 1999.

BRUNAUER, S.; EMMETT, P. H.; TELLER, E. Adsorption of gases in multimolecular layers. J. Am. Chem. Soc., v. 60, p. 309-319, 1938.

BUNKER, B. C.; RIEKE, P. C.; TARASEVICK, B. J.; CAMPBELL, A. A.; FRYXELL, G. .; GRAFF, G. L.; SANG, L.; LIU, J.; VIRDEN, J. W.; McVAY, G. L. Ceramic thin-film formation on functionalized interfaces through biominetic processing. Science, v.264, p.48-55, 1994.

CAFFREY, M.; BILDERBACK, D. H. Real-time x-ray-difraction using synchrotron radiation - system characterization and applications. Nuclear Instrum. Meth., v.208, p.495-510, 1983.

CAMPANHÃ, M. T. N.; MAMIZUKA, E. M.; CARMONA-RIBEIRO, A. M. Interactions between cationic liposome and bacteria: the physical-chemistry of the bactericidal action. J. Lipid Research, v.40, p.1495-1500, 1999.

CARMONA-RIBEIRO, A. M. Does DLVO account for interaction between charged spheric vesicles? J. Phys. Chem., v. 96, p.9555-9557, 1992.

CARMONA-RIBEIRO, A. M. Interaction between charged spheric vesicles. J. Phys. Chem., v.97, p.11843-11846, 1993.

CARMONA-RIBEIRO, A. M. Reply to comment on "Does DLVO account for interaction between charged spheric vesicles?” J. Phys. Chem., v.97, p. 4747, 1993. 
CARMONA-RIBEIRO, A. M. Synthetic amphiphile vesicles. Chem. Soc. Reviews, v.21, p.209-214, 1992.

CARMOP ${ }^{\top}$ A-RIBEIRO, A. M.; CASTUMA, C. E.; SESSO, A.; SCHREIER, S. Bilayer structure and stability in dihexadecyl phosphate dispersions. J. Phys. Chem., v.95, p.5361-5366, 1991.

CARMONA-RIBEIRO, A. M.; CHAIMOVICH, H. Preparation and characterization of large dioctadecyldimethylammonium chloride liposomes and comparison with small sonicated vesicles. Biochim. Biophys. Acta., v. 773, p.172179, 1983.

CARMONA-RIBEIRO, A. M.; CHAIMOVICH, H. Salt-induced aggregation and fusion of dioctadecyldimethylammonium chloride and sodium dihexadecylphosphate vesicles. Biophys. J., v.50, p.621-628, 1986.

CARMONA-RIBEIRO, A. M.; HERRINGTON. T. M. Phospholipid adsorption onto polystyrene microspheres. J Colloid Interface Sci., v.156, p.19-23, 1993.

CARMONA-RIBEIRO, A. M.; HIX, S. pH effects on proprerties of dihexadecyl phosphate vesicles. J. Phys. Chem., v.95, p.1812-1817, 1991.

CARMONA-RIBEIRO, A. M.; LESSA, M. M. Interactions between bilayer membrane and latex. Colloids Surf. A, v.153, p.355-361, 1999.

CARMONA-RIBEIRO, A. M.; MIDMORE, B. R. Synthetic bilayer adsorption onto polystyrene microspheres. Langmuir, v.8, p.801-806, 1992.

CARMONA-RIBEIRO, A. M.; YOSHIDA, L. S.; SESSO, A.; CHAIMOVICH, H. Permeabilities and stabilities of large dihexadecylphosphate and dioctadecyldimethylammonium chloride vesicles. J. Colloid Interface Sci., v. 100, p.433-443, 1984.

CHARITAT, T.; BELLET-AMALRIC, E.; FRAGNETO; G.; GRANER, F. Adsorbed and free lipid bilayers at the solid-liquid interface. Eur. Phys. J. B, v.8, p.583-593, 1999;

CHIOU, Y. L.; SOW, C. H.; LI, G.; PORTS, K. A. Growth-characterization of silicon dioxide procedure by rapid thermal-oxidation process. Appl. Phys. Lett., v.57, p.881-883, 1990.

CLAESSON, P. M.; BLOM, C. E.; HERDER, P. C.; NINHAM, B. W. Interactions between water-stable hydrophobic Langmuir-Blodgett monolayers on mica. J. Colloid Interface Sci., v. 114, p. 234-242, 1986.

CLARENCE, N. A. M.; NEOGI, P. Interfacial phenomena Surfactant Science Series, 1 ed. Marcel Dekker Inc., 1985.

CREMER, P. S.; BOXER, S. G. Formation and spreading of lipid bilayers on planar glass support. J. Phys. Chem. B, v.103, p.2554-2559, 1999. 
CrEmER, P. S.; GROVES, J. T.; KUNG, L. A.; BOXER, S. G. Writing and erasing barriers to lateral mobility into fluid phospholipid bilayers. Langmuir, v.15, p.3893-3896, 1999.

DE ROSSI, D.; AHLUWALIA, A.; MULÉ, M. Molecular and supramolecular systems for sensing and actuation, IEEE - Engineering in medicine and biology, v.13; p.103-111, 1994.

DEAMER, D.; BANGHAM, A. D. Large volume liposomes by an ether vaporization method. Biochim. Biophys. Acta, v.443, p.629-634, 1976.

DEGUSSA S/A. Amorphous synthetic silica products in powder form production and characterization. Technical Bulletin Pigments, v.32, 1980.

DEGUSSA S/A. Basic Characteristics of AEROSIL ®. Technical Bulletin Pigments, v.11, 4ed., 1993.

DOMAGK, G. Eine neue Klasse von Disinfektionsmitteln. Dtsh. Med. Wochenschr., v.61, p.829, 1935.

DOS SANTOS FILHO, S. G.; HASENACK, C. M. Achievement of high quality thin gate oxides grown by rapid thermal oxidation of silicon. J. Solid-State Devices and Circuits, v.3, p.1-9, 1995.

DOS SANTOS FILHO, S. G.; HASENACK, C. M. SALAY, L. C.; MERTENS, P. W. A less critical cleaning procedure for silicon wafers using diluted $\mathrm{HF}$ dip and boiling in isopropyl alcohol as final steps. J. Eletrochem. Soc., v.142, p.902-907, 1995.

EASTON, T. G.; VALINSKY, J. E.; REICH, E. Merocyanine 540 as a fluorescence - probe of membranes - staining of electrically excitable cells. Cell, v.13, p.475-486, 1978.

ENDERLEIN, R. Microeletrônica - Uma introdução ao universo dos microships, seu funcionamento, fabricação e aplicações. 1 ed. EDUSP, 1994.

ESUMI, K.; SUGIMURO, A.; YAMADA, T.; MEGURO, K. Adsorption of dioctadecyldimethylammonium chloride on silica. Colloid and Surf., v.62, p.249254, 1992.

EVANS, D. F.; WENNERSTRÖM, H. The colloidal domain - Where physics, chemistry, biology and technology meet., 1 ed., VCH Publishers, Inc., 1994.

FENDLER, J. H. Surfactants vesicles as membrane mimetic agents characterization and utilization. Accounts Chem. Res., v.13, p.7-13, 1980.

FIROUZI, A.; KUMAR, D.; BULL, L. M.; BESIER, T.; SIEGER, P.; HUO, Q., WALKER, S. A.; ZASADZINSKI, J. A.; GLINKA, C.; NICOL, J.; MARGOLESE, D.; STRUCKY, G. D.; CHMELKA, B. F. Cooperative organization of inorganic-surfactant and biomimetic assemblies. Science, v.267, p.1138-1143, 1995. 
GENNIS, R. B. Biomembranes: molecular structure and function. 1 ed., New York, Springer Verlag, Inc, 1989.

GILES, C. H.; MacEWAN, T. H.; NAKHWA, S. N.: SMITH, D. Studies in adsorption. Part XI. A system of classification of solutions adsorption isotherms, and its use in diagnosis of adsorption mechanisms and in measurements of specific surface areas of solids. J. Chem. Soc., p.3973-3993, 1960.

GOOD, R. J. Contact angle, wetting and adhesion: a critical review. In: MITTAL, K. L. Contact angle wettability and adhesion. Utrecht, VSP, 1993, p.3-36.

GUGLIOTTI, M.; POLITI, M. J.; CHAIMOVICH, H. Phase transition temperature of vesicles determined by surface tension measurements: a fast method. J. Colloid Interface Sci., v.198, p.1-5, 1998.

HARWIGSSON, I.; TIBERG, F.; CHEVALIER, Y. Nature of the adsorption of zwitterionic surfactants at hydrophilic surfaces. J. Colloid Interface Sci., v.183, p.380-387, 1996.

HELM, C. A.; ISRAELACHVILI, J. N.; McGUiGGAN, P. M. Molecular mechanisms and forces involved in the adhesion and fusion of amphiphilic bilayers. Science, v.246, p.919-922, 1989.

HIEMENZ, P. C. Principles of colloid and surface chemistry. 2 ed., New York, Marcel Dekker, INC, 1986.

HUANG, C.H. "Studies on phosphatidylcholine vesicles. Formation and physical characteristics" Biochemistry, v.8, p.344-351, 1969.

ISRAELACHVILI, J. N. Intermolecular and Surface Forces. 2 ed. London, Academic Press, 1992.

ISRAELACHVILI, J. N.; GEE, M. L. Contact angle on chemically heterogeneous surfaces. Langmuir, v.5, p.288-289, 1989.

ISRAELACHVILI, J. N.; MITCHELL, D. J.; NINHAM, B. W. Theory of selfassembly of lipid bilayers and vesicles. Biochim. Biophys. Acta, v.470, p.185-201, 1977.

ISRAELACHVILI, J. N.; WENNERSTRÖM, H. Hydration or steric forces between amphiphilic surfaces. Langmuir, v.6, p.837-876, 1990.

JACKSON, S.; REBOIRAS, M. D.; LYLE, I. G.; JONES, M. N. Adsorption of phospholipid vesicles on solid surfaces. Faraday Discuss. Chem. Soc., v.81, p.291-301, 1986.

JACKSON, S.; REBOIRAS, M. D.; LYLE, I. G.; JONES, M. N. The mechanism of phospholipid adsorption from vesicle dispersions onto glass surfaces. Colloids Surf., v.27, p.325-340, 1987. 
JAURAND, M. C.; BAILLIF, P.; THOMASSIN, J. H.; MAGNE, L.; TOURAY, J. C., X-ray photoelectron-spectroscopy and chemical study of the adsorption of biological molecules on chrysotile asbestos surface. J.Colloid Interface Sci., v.95, p.1-9, 1983.

JEON, S. I.; LEE, J. H.; ANDRADE, J. D.; deGENNES, P. G. Protein surface interactions in the presence of polyethylene oxide. 1. Simmplified theory. J. Colloid Interface Sci., v.142, p.149-158, 1991

JOHNSON, R. E.; DETTRE, R. H.; BRANDRETH, D. A. Dynamic contact angles and contact angle hysteresis. J. Colloid Interface Sci., v.62, p.205-212, 1977.

JÖNSSON U.; MALMQVIST, M.; RÖNNERBERG, I. Adsorption of immunoglobulin $G$, protein $A$, and fibronectin in the submonolayer region evaluated by a combined study of ellipsometry and radiotracer techniques. J. Colloid Interface Sci., v.103, p.360-372, 1985.

KALB, E.; ENGEL, J.; TAMM,. L. K. Binding of proteins to specific target sites in membranes measured by total internal reflection fluorescence microscopy. Biochemistry, v.29, p.1607-1613, 1990.

KALB, E.; FREY, S.; TAMM, L. K. Formation of supported planar bilayers by fusion of vesicles to supported phospholipid monolayer. Biochim. Biophys. Acta, v.1103, p.307-316, 1992.

KANO, K.; ROMERO, A.; DJERMOUNI, B.; ACHE, H.; FENDLER, J. H. Characterization of surfactant vesicle as a membrane mimetic agent. 2 temperaturedependent changes of turbidity, viscosity, fluorescence polarization of 2methylantracene, and positron annihilation in sonicated dioctadecyldimethylammoniun chloride. J. Am. Chem. Soc., v.101, p.4030-4037, 1979.

KASBAUER, M.; JUNGLAS, M.; BAYERL, T. M. Effect of cationic lipids in the formation of asymmetries in supported bilayers. Biophys. J., v.76, p.2600-2605, 1999.

KATZ, L. E. Oxidation. In: SZE, S. M. VLSI Technology. Singapore, McGrawHill, 1990, p.131-167.

KOMATSU, H.; ROWE, E. S. Effect of cholesterol on the ethanol-induced interdigitated gel phase in phosphatidylcholine - use of fluorophore pyrene-labeled phosphatidylcholine. Biochemistry, v.30, p.2463-2470, 1991.

KREMER, J. M. H.; ESKES, M. W. J. V. D.; PATHMAMANOHARAN, C.; WIERSEMA, P. H. Vesicles of variable diameter prepared by a modified injection method. Biochemistry, v.16, p.3932-3935, 1977. 
KUNITAKE, T. Chemistry of self-assembling bilayers and related molecular layers. Materials Research Society (MRS) Bulletin, v.20, n.6, p.22-25, 1995.

KUNITAKE, T.; OK AHATA, Y.; TAMAKI, K.; JUMAMARU, F.; TAKAYANAGI, M. Formation of the bilayer membrane from a series of quartenary ammonium salts. Chem. Lett., n.4, p.387-390, 1977.

LASIC, D. D. Sterically stabilized vesicles. Angew. Chem. Int. Edit. Engl., v.33, p.1685-1698, 1994.

LELKES, P. I.; MILLER, I. R. Perturbations of membrane-structure by optical probes .1. Location and structural sensitivity of merocyanine-540 bound to phospholipid-membranes. J.Membrane Biol., v.52,p. 1-15, 1980.

LESSA, M. M.; CARMONA-RIBEIRO A. M. Bilayer wetting on polymer surfaces. J. Colloid Interface Sci., v.182, p.166-171, 1996.

LIPTROT, G. F. Modern Inorganic Chemistry, 4 ed. London, Unwin Hyman Limited, 1989.

LUCIANI, L.; DENOYEL, R. Adsorption of polydisperse surfactants on solid surfaces: an ellipsometric study. J. Colloid Interface Sci., v.188, p.75-80, 1997.

MALMSTEN, M. Ellipsometry studies of protein layers adsorbed at hydrophobic surfaces. J. Colloid Interface Sci., v.166, p.333-342, 1994.

MALMSTEN, M.; BERGENSTÅHAL, B; MASQUELIER, M.; PÅLSSON, M.; PETERSON, C. Adsorption of apolipoprotein B at phospholipid model surfaces. J. Colloid Interface Sci., v.172, p.485-493, 1995.

MARMUR, A. Equilibrium contact angle: theory and measurement. Colloids Surf. A, v.116, p.55-61, 1996.

McCONNEL, H. M.; WATTS, T. H.; WEIS, R. M.; BRIAN, A. A. Supported planar membranes in studies of cell-cell recognition in the immune system. Biochim. Biophys. Acta, v.864, p.95-106, 1986.

MILONJIĆ, S. Determination of surface ionization and complexation constants at colloidal silica/electrolyte interface. Colloids Surf., v.23, p.301-312, 1987.

MORTARA, R. A.; QUINA, F. H.; CHAIMOVICH, H. Formation of closed vesicles from a simple phosphate diester. Preparation of some properties of vesicles of dihexadecyl phosphate. Biochem. Biophys. Res. Co., v.81, p.1080-1086, 1978.

MORTIMER, C. Chemistry - A Conceptual Approach. 2 ed. New York, D. Van Nostrand Company, 1971.

NARDI, J.; BRUINSMA, R.; SACKMANN, E. Adhesion-induced reorganization of charged fluid membranes. Phys. Rev. E, v.58, p.6340-6354, 1998. 
NASCIMENTO, D. B.; RAPUANO, R.; LESSA, M. M.; CARMONA-RIBEIRO, A. M. Counterion effects on properties of cationic vesicles. Langmuir, v.14, p.7387-7391, 1998.

NEW, R. R. C. Liposomes - A Practical Approach. 1 ed. New York, IRL Press, 1994.

O'BRIEN, J. M.; MONTGOMERY, R. R.; BURNS, W. H.; GAFFNEY, D. K.; SIEBER, F. Evaluation of merocyanine-540 - sensitized photoirradiation as a means to inactivate enveloped viruses in blood products. J. Lab. Clin. Med., v.116, p.439-447, 1990.

OHKI, S.; OHSHIMA, H. Interaction and aggregation of lipid vesicles (DLVO theory versus modified DLVO theory). Colloids Surf. B, v.14, p.27-45, 1999.

OTTEWILL, R. H. Surfactants - Introduction in: TADROS, TH. F. Surfactants London, Academic Press, p. 1-18, 1984.

PADDAY, J. F. Spreading, Wetting and Contact Angles. In: MITTAL, K. L. Contact angle, wettability and adhesion. Utrecht,VSP, 1993, p. 421-435.

PANSU, R. B.; ARRIO, B.; RONCIN, J.; FAURE, J. Vesicles versus membrane fragments in DODAC suspensions. J. Phys. Chem., v.94, p.796-801, 1990.

PASHLEY, R. M. Electromobility of mica particles dispersed in aqueous-solutions. Clay Clay Minerals, v.33, p.193-199, 1985.

PASHLEY, R. M.; MCGUIGGAN, P. M.; NINHAM, B. W.; BRADY, J.; EVANS, D. F. Direct measurements of surface forces between bilayers of double-chained quaternary ammonium acetate and bromide surfactants. J. Phys. Chem., v.90, p.1637-1642, 1986.

POHL, G. W. Spectral properties of fluorescence dyes in lecithin vesicles - probes for structure of lipid bilayer membranes and for membrane-potencials. $\mathbf{Z}$. Naturforsch. C, v.31, p.575-588, 1976.

RABOCKAI, T. Físico-Química de superfícies. 1 ed. Washington D.C., Secretaria Geral da Organização dos Estados Americanos - Programa Regional de Desenvolvimento Científico e Tecnológico, 1979.

RAMDSEN, J. J.; SCHNEIDER, P. Membrane insertion and antibody recognition of a glycosylphosphatidylinositol-anchored protein: an optical study. Biochemistry, v.32, p.523-529, 1993.

RAPUANO, R.; CARMONA-RIBEIRO, A. M. Physical adsorption of bilayer membranes on silica. J. Colloid Interface Sci., v.1993, p.104-111, 1997.

ROUSER, G.; FLEISCHER, S., YAMAMOTO, A. Two dimensional thin layer chromatographic separation of polar lipids and determination of phospholipids by phosphorous analysis spots. Lipids, v.5, p.494-496, 1970. 
SALAY, L. C., Efeito de vesículas sintéticas ou fosfolipídicas sobre a molhabilidade de superfícies planares de óxido de silício. Dissertação de Mestrado - EPUSP 1997.

SALAY, L. C.; CARMONA-RIBEIRO, A. M., Synthetic bilayer wetting on $\mathrm{SiO}_{2}$ surfaces. J. Phys. Chem. B, v.102, p.4011-4015, 1998.

SCHALES, O.; SCHALES S. S. A simple and accurate method for determination of chloride in biological fluids. J. Biol. Chem., v.140, p.879-884, 1941.

SCHIMIDT, A.; SPINKE, J.; BAYERL, T.; SACKMANN, E.; KNOLL, W. Streptavidin binding to biotinylated lipid layers on solid supports. Biophys. J., v.63, p. 1185-1192, 1992.

SCHULLERY, S. E.; GARZANITI, J. P. Studies on phosphatidylcholine models membranes. I. Size-Heterogeneity effect on permeability measurements. Chem. Phys. Lipids, v.12, p.75-95, 1973.

SEARS JR, G. W. Determination of specific surface area of colloidal silica by titration with sodium hydroxide. Anal. Chem., v. 28, p.1981-1983, 1956.

SEIFERT, K.; FENDLER, K.; BAMBERG, E. Charged transport by ion translocating membrane proteins on solid supported membranes. Biophys. J., v.64, p.384-391, 1993.

SHAW, D. J. Introduction to colloid and surface chemistry. 2 ed. Editora Edgard Blücher Ltd., 1975.

SICCHIEROLLI, S. M.; CARMONA-RIBEIRO, A. M. Biomolecular recognition at phospholipid-covered polystyrene microspheres. J. Phys. Chem. B, v.100, p.16771-16775, 1996.

SICCHIEROLLI, S. M.; CARMONA-RIBEIRO, A. M. Incorporation of the cholera-toxin receptor in phospholipid-covered polystyrene microspheres. Colloids Surf. B, v.5, p.57-61, 1995.

SICCHIEROLLI, S. M.; MAMIZUKA, E. M.; CARMONA-RIBEIRO, A. M. Bacteria flocculation and death by cationic vesicles. Langmuir, v.11, p.2991-2995, 1995.

SIEBER, F. Merocyanine-540.Photochem. Photobiol., v.46, p.1035-1042, 1987

SIEBER, F.; SPIVAK, J. K.; SUTCLIFFE, A. M. Selective killing of leukemic-cells by merocyanine 540 - mediated photosensitization. P. Natl. Acad. Sci. US - Biol. Sci., v.81, p.7584-7587, 1984.

ŠIKUROVÁ, L.; ČUNDERLÍKOVÁ, B. pH dependence of merocyanine 540 absorption and fluorescence spectra. Spectrochim. Acta A, v.53, p.293-297, 1997. 
STELMO, M.; CHAIMOVICH, H.; CUCCOVIA, I. M. Quantitativedetermination of alkylammonium amphiphiles using neutral detergents. J. Colloid Interface Sci., v.117, p.200-204, 1987.

STELZLE, M.; SACKMANN, E. Sensitive detection protein adsorption to supported lipid bilayers by frequency - dependent capacity measurements and microeletrophoresis. Biochim. Biophys. Acta, v.981, p.135-142, 1989.

STELZLE, M.; WEISSMÜLLER, G.; SACKMANN, E. On the application of supported bilayer as receptive layers for biosensors with electrical detection. J. Phys. Chem., v.97, p.2974-2981, 1993.

STEMME, S.; ODBERG, L. Layer thickness for high molecular weight cationic polyacrylamides adsorbed on a surface with a preadsorbed poly-diallyl. Colloids Surf. A, v.157, p.307-313, 1999.

STROM, C. JÖNSSON, B.; SODERMAN, O.; HANSSON, P. Adsorption of a divalente cationic surfactant onto silica surface. Colloids Surf. A, v.159, p.109-120, 1999.

TADROS, TH. F.; LYKLEMA, J. Adsorption of potential-determining ions at the silica-aqueous electrolyte interface and the role of some cations. J. Electroanal. Chem., v.17, p.267-275, 1968.

TAMM, L. K.; BÖHM, C.; YANG, J.; SHAO, Z.; HWANG, J.; EDIDIN, M.; BETZIG, E. Nanostructure of supported phospholipid monolayers and bilayers by scanning probe microscopy. Thin Solid Films, v.284, p.813-816, 1996.

TAMM, L. K.; McCONNELL, H. M. Supported phospholipid bilayers. Biophys. J., v.47, p.105-113, 1985.

TANFORD, C. The hydrophobic effect. Formation of micelles and biological membranes. 2 ed., New York, John Wiley \& Sons, Inc., 1980.

TAPIAS, G. N.; SICCHIEROLLI, S. M.; MAMIZUKA, E. M.; CARMONARIBEIRO, A. M. Interactions between cationic vesicles and Eschericbia coli. Langmuir, v.10, p.3461-3465, 1994.

TIBERG, F.; JÖNSSON, B.; LINDMAN, B. Ellipsometry studies of the selfassembly of nonionic surfactants at the silica-water interface: kinetic aspects. Langmuir, v.10, 3714-3722, 1994.

TIBERG, F.; JÖNSSON, B.; TANG, J.; LINDMAN, B. Ellipsometry studies of the self-assembly of nonionic surfactants at the silica-water interface: equilibrium aspects. Langmuir, v.10, 2294-2300, 1994.

TIBERG, F.; LANDGREN, M. Characterization of thin nonionic surfactant films at the silica/water interface by means of ellipsometry. Langmuir, v.9, p.927-932, 1993. 
TRAN, Y. AUROY, P. LEE, L. T. Determination of the structure of polyelectrolyte brushes. Macromolecules, v.32, p.8952-8964, 1999.

TSURUTA, L. R.; CARMONA-RIBEIRn, A. M. Counterion effects on colloid stability of cationic vesicles and bilayer-covered polystyrene microspheres. J. Phys. Chem., v.100, p.7130-7134, 1996.

WAGBERG, L.; NYGREN, I. The use of stagnation point adsorption reflectomery to study molecular interactions relevant to papermaking chemistry. Colloid Surface A, v.159, p.3-15, 1999.

WÄNGNERUD, P.; JÖNSSON, B. Adsorption of ionic amphiphiles as bilayers on charged surfaces. Langmuir, v.10, p.3268-3278, 1994.

WÄNGNERUD, P.; JÖNSSON, B. Ionic surfactants at the charged solid/water interface: significance of premicellar aggregation. Langmuir, v.10, p.3542-3549, 1994.

WILLIAMSON, P. L.; MASSEY, W. A.; PHELPS, B. M.; SCHLEGEL, R. A. Membrane phase state and the rearrangement of hematopoietic cell surface receptors. Mol. Cell. Biol., v.1, p.128-135, 1981.

WILLIAMSON, P. L.; MATTOCKS, K.; SCHLEGEL, R. A. Merocyanine 540, a fluorescent probe sensitive to lipid packing. Biochim. Biophys. Acta, v.732, p.387-393, 1983. 